\title{
HYDROGEOLOGY, WATER QUALITY, AND GROUND-WATER-DEVELOPMENT ALTERNATIVES IN THE UPPER WOOD RIVER GROUND-WATER RESERVOIR, RHODE ISLAND
}

By David C. Dickerman and Richard W. Bell

\section{U.S. GEOLOGICAL SURVEY}

Water-Resources Investigations Report 92-4119

Prepared in cooperation with the

RHODE ISLAND WATER RESOURCES BOARD

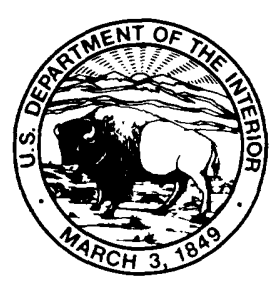

Providence, Rhode Island 1993 


\title{
U.S. DEPARTMENT OF THE INTERIOR
}

Bruce Babbitt, Secretary

\author{
U.S. GEOLOGICAL SURVEY \\ Dallas L. Peck, Director
}

For additional information, write to:

U.S. Geological Survey

John O. Pastore Federal Bldg.

and U.S.P.O., Room 237

Providence, R.I. 02903-1720
Copies of this report can be purchased from:

U.S. Geological Survey

Books and Open-File Reports Section

Box 25424, Federal Center

Denver, CO 80225 


\section{CONTENTS}

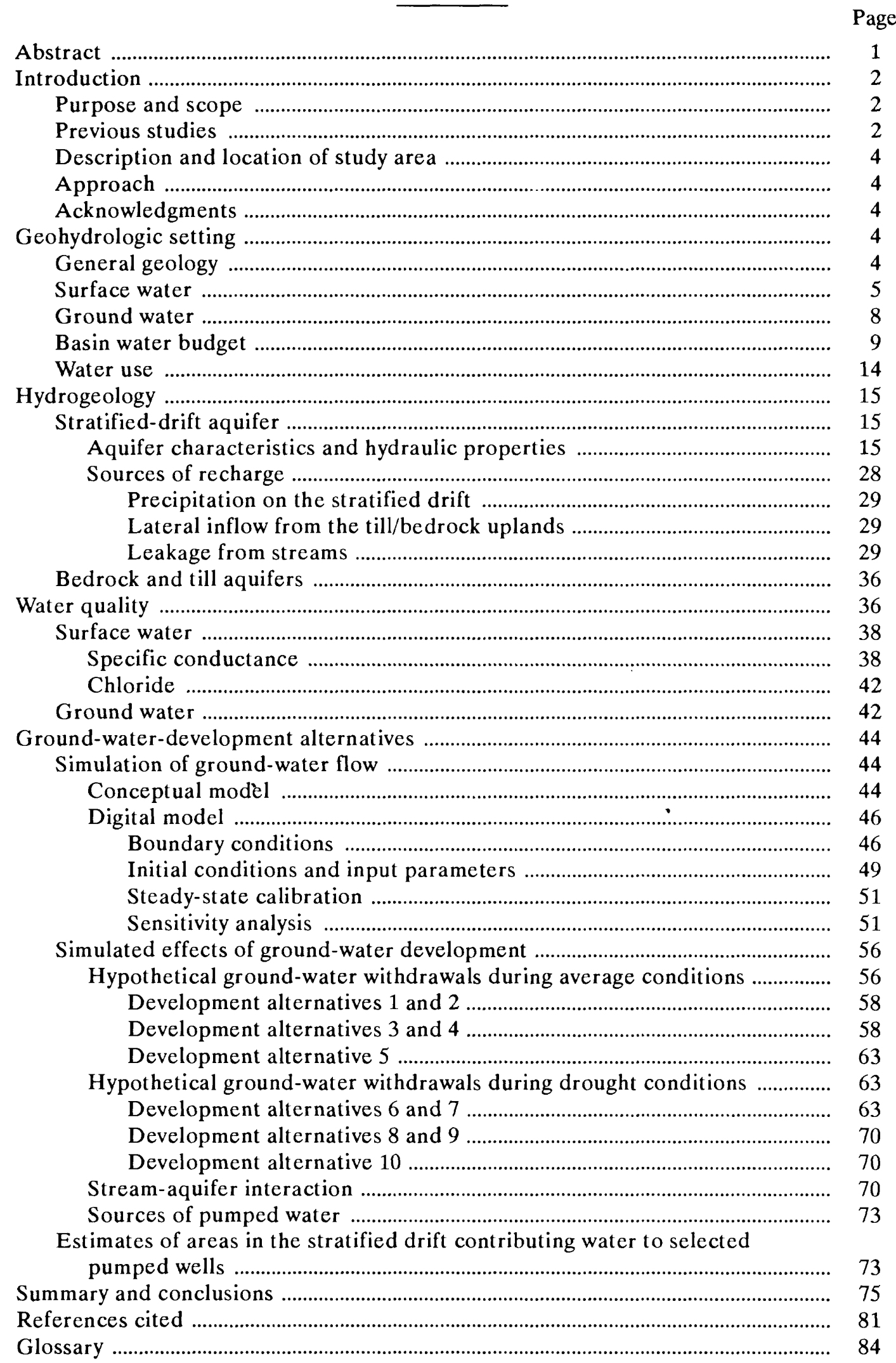




\section{ILLUSTRATIONS}

Figure 1. Map showing location and generalized hydrogeology of the upper Wood River study area in $\mathrm{Rhode}$ Island and the area represented by the ground-water model

2. Map showing location of selected wells, streamflow-gaging stations, and geologic sections in the upper Wood River study area

3. Graph showing duration of daily mean stream discharge of the Wood River at Arcadia and at Hope Valley

4. Map showing water table in the stratified-drift aquifer in the upper Wood River study area, December 1982

5. Graph showing monthly water-level fluctuations of Wood River near Arcadia and in selected wells in the upper Wood River study area

6. Graphs showing annual precipitation (A) and departure from average precipitation (B) at Kingston, and annual runoff (C) and departure from average runoff (D) of the Wood River at Hope Valley, 1942-89

7. Map showing bedrock surface in the upper Wood River study area

8. Geologic section (A-A') of the upper Wood River ground-water reservoir

9-13. Generalized geologic section:

9. B-B' near Plain Road

10. C-C' along State Highway 165

11. D-D' north of Deep Pond

12. E-E' north of Barberville

13. F-F' along Skunk Hill Road

14. Map showing saturated thickness in the stratified-drift aquifer in the upper Wood

River study area
15. Map showing transm study area

16. Map showing surface-water-quality sampling sites in the upper Wood River study

17. Graph showing relation between dissolved-solids concentration and specific

conductance for streams in the upper Wood River study area

18. Graph showing specific conductance and stream discharge for the Wood River at Hope Valley, April 29-July 29, 1986

19. Graph showing concentrations of selected dissolved constituents for the Wood River at Arcadia and at Hope Valley, November 13, 1978

20. Diagram showing natural system and idealized conceptual model of steady-state ground-water flow

21. Map showing finite-difference grid and identification of stream segments for the upper Wood River ground-water model

22. Map showing horizontal hydraulic conductivity used in the ground-water model of the upper Wood River stratified-drift aquifer

23. Map showing water-table altitude measured in observation wells, December 1982 and simulated steady-state water-table contours for nonpumping, long-term, average annual conditions, upper Wood River study area, 1942-89

24. Box plots showing statistical distribution of the difference between measured and calculated water-table altitudes for sensitivity tests of the steady-state model

25-30. Maps showing simulated steady-state water-table or drawdown contours for long-term average annual conditions:

25. Water table, development alternative 1, pumping 6 million gallons per day from the northern part of the upper Wood River study area 


\section{ILLUSTRATIONS (continued)}

26. Water table, development alternative 2, pumping 6 million gallons per day from the southern part of the upper Wood River study area

27. Drawdown, development alternative 1, pumping 6 million gallons per day from the northern part of the upper Wood River study area

28. Drawdown, development alternative 2, pumping 6 million gallons per day from the southern part of the upper Wood River study area

29. Water table, development alternative 5, pumping 12 million gallons per day, upper Wood River study area

30. Drawdown, development alternative 5, pumping 12 million gallons per day, upper Wood River study area

31-34. Maps showing simulated steady-state water-table contours for drought conditions:

31. Nonpumping, upper Wood River study area

32. Development alternative 6 , pumping 6 million gallons per day from the northern part of the upper Wood River study area

33. Development alternative 7, pumping 6 million gallons per day from the southern part of the upper Wood River study area

34. Development alternative 10, pumping 12 million gallons per day, upper Wood River study area

35. Map showing estimated areas in the stratified drift contributing water to wells pumped during development alternative 1, northern part of the upper Wood River study area

36. Map showing estimated areas in the stratified drift contributing water to wells pumped during development alternative 2, southern part of the upper Wood River study area

37. Map showing estimated areas in the stratified drift contributing water to wells pumped during development alternative 5, upper Wood River study area

\section{TABLES}

Table 1. Estimated long-term average annual runoff at partial-record stations ............................... 8

2. Long-term average annual water budget (1942-89) ............................................................ 14

3. Assumptions used in analysis of aquifer-test data ................................................................. 28

4. Summary of hydraulic properties determined from aquifer tests of the stratified-drift aquifer

5. Summary of chemical and physical properties of ground water and surface water in the study area

6. Summary of specific conductance at selected surface-water sites

7. Summary of dissolved-chloride concentrations and specific conductance at selected surface-water sites

8. Concentrations of selected metals and synthetic organic compounds in ground water in the study area

9. Measured and computed water-table altitudes for selected observation wells, December 1982

10. Simulated steady-state water budget for the ground-water model, nonpumping conditions 


\section{TABLES (continued)}

11. Principal input parameters changed during sensitivity analysis for the steady-state simulation

12. Selected ground-water-development alternatives tested for steady-state conditions ..... 57

13. Drawdowns from 2-day aquifer tests and simulated steady-state drawdowns during development alternative 5 , with pumping 12 million gallons per day

14. Stream leakage to or from stream segments for nonpumping and pumping conditions under selected long-term average annual and drought conditions

15. Source and relative percentages of water withdrawn from wells during ground-waterdevelopment alternatives 1 through 10

\section{CONVERSION FACTORS, VERTICAL DATUM, AND ABBREVIATED WATER-QUALITY UNITS}

Multiply

inch (in.)
foot (ft)
mile (mi)

acre

square mile $\left(\mathrm{mi}^{2}\right)$

cubic foot $\left(\mathrm{ft}^{3}\right)$

gallon (gal)
By

Length

25.4

0.3048

1.609

Area

0.4047

2.590

$\underline{\text { Volume }}$

0.02832

3.785

Flow

cubic foot per second $\left(\mathrm{ft}^{3} / \mathrm{s}\right)$

0.02832

0.01093

0.06309

0.04381

million gallons per day

(Mgal/d)
To obtain

millimeter

meter

kilometer

hectare

square kilometer

cubic meter

liter

cubic meter per second

cubic meter per second per square kilometer

liter per second

cubic meter per second 


\title{
Hydrogeology, Water Quality, and Ground-Water- Development Alternatives in the Upper Wood River Ground-Water Reservoir, Rhode Island
}

\author{
By David C. Dickerman and Richard W. Bell
}

\section{ABSTRACT}

The 72.4-square-mile upper Wood River study area is in the Pawcatuck River basin in southern Rhode Island. Stratified drift is the only principal geologic unit capable of producing yields greater than 0.5 million gallons per day. The stratified-drift aquifer consists of interbedded lenses of sand and gravel and lesser amounts of silt, silty sand, and clay. Transmissivity of the aquifer ranges from about 7,600 to 49,200 square feet per day. Water-table conditions prevail in the aquifer, which is in good hydraulic connection with perennial streams and ponds.

The quality of ground water in the study area is generally good to excellent and the water is suitable for most uses, including drinking. The water is soft, slightly acidic, and typically contains less than 150 milligrams per liter dissolved solids. Locally, however, ground water has been contaminated with nitrate, chloride, and volatile organic compounds associated with various land-use and waste-disposal activities. In some areas, concentrations of iron and manganese exceed secondary maximum contaminant levels established by the Rhode Island Department of Health.

A finite-difference model of the ground-waterflow system was used to simulate the interaction between surface water and ground water. The model was used to evaluate the effect of alternative schemes of ground-water development on ground-water levels and streamflow in the upper Wood River groundwater reservoir. Steady-state simulations of pumpage were made for long-term average annual conditions (1942-89) and simulated drought conditions (196366). The model was used to simulate changes in stream leakage and to estimate the percentage of water withdrawn from wells that would be derived from ground-water runoff, induced recharge, and reduced evaporation and transpiration.

Differences between computed and measured water-table altitudes in 37 observation wells ranged from - 6.6 to 11.4 feet, but were less than 3 feet at 57 percent of the observation-well cells. The mean absolute error of the residuals of these differences is 3.0 feet, and the root mean square error is 3.7 feet. Total pumpage for selected development-alternative simulations ranged from 6 to 12 million gallons per day. Individual wells were pumped at constant rates of 1 or 1.5 million gallons per day for all simulations.

The areas most favorable for development of high-capacity wells (1 million gallons per day or more) are along the Flat and Wood Rivers. According to results of the simulations, 50 to 65 percent of the water withdrawn from wells will be derived from induced recharge from surface-water sources.

Simulation of development alternatives considered in this study indicates that the ground-water reservoir can sustain withdrawals of 6 to 12 million gallons per day from 11 wells under both steady-state (1942-89) conditions and drought (1963-66) conditions without causing an excessive decrease in aquifer saturated thickness. Pumping 12 million gallons per day, however, would reduce the flow of the Wood River at the basin outlet at the Hope Valley streamflow-gaging station by about 18 cubic feet per second, an amount almost equal to the 7-day, 10-year low flow of 20.4 cubic feet per second.

A particle-tracking postprocessing software package was used to estimate areas in the stratified drift contributing water to selected pumped wells. Contributing areas are shown for minimum (6 million gallons per day) and maximum (12 million gallons per day) pumping simulations in the upper Wood River ground-water reservoir. 


\section{INTRODUCTION}

Stratified-drift ${ }^{1}$ deposits, primarily in stream valleys, are Rhode Island's major aquifers. Where the transmissivity and saturated thickness of these aquifers are greatest, ground water may be present in quantities suitable for development and use; such aquifers are termed ground-water reservoirs. The upper Wood River ground-water reservoir is in the Pawcatuck River basin, in southern Rhode Island. The reservoir underlies an area of approximately $8 \mathrm{mi}^{2}$ in the valleys drained primarily by the Flat and Wood Rivers above the U.S. Geological Survey (USGS) streamflow-gaging station on the Wood River at Hope Valley. To increase understanding of the ground-water-flow system in the area, a digital model was used to simulate various ground-water development alternatives. The outline of the groundwater model, shown in figure 1 , approximates the area of the upper Wood River ground-water reservoir. The upper Wood River ground-water reservoir is one of nine major ground-water reservoirs in the Pawcatuck River basin (Rhode Island Statewide Planning Program, 1979), and one of five in which the Rhode Island Water Resources Board (RIWRB) has done extensive exploratory drilling and aquifer testing.

The RIWRB, which is responsible for implementing development of the State's major water resources, identifies sites at which high-capacity wells can be developed to yield water of suitable quality for municipal supply. This responsibility led to the development of a cooperative study between the RIWRB and the USGS, which involved the collection and analysis of geohydrologic data in each of five ground-water reservoirs in the Pawcatuck River basin. The upper Wood River project addresses the problem of supply and demand identified by the USGS as a priority issue for study under the FederalState Cooperative Program. The study provides better aquifer-plan system definition and simulation of ground-water withdrawals essential for aquifer management. The RIWRB proposes to encourage development and management of ground-water resources to minimize streamflow depletion during low-flow periods. In the upper Wood River groundwater reservoir, various sites were tested to determine the potential for the stratified-drift aquifer to

${ }^{1}$ Boldface terms in text are defined in the glossary. yield $1 \mathrm{Mgal} / \mathrm{d}$ or more to individual wells. The RIWRB also proposes to preserve well sites that can produce $1 \mathrm{Mgal} / \mathrm{d}$ or more for future water-supply development.

\section{Purpose and Scope}

This report describes the hydrogeology, water quality, and ground-water-development alternatives in the upper Wood River ground-water reservoir, Rhode Island. The report includes discussion of (1) recharge to and hydraulic properties of the stratifieddrift aquifer, (2) stream-aquifer interconnection, (3) assessment of the quality of ground water and surface water, (4) input to and calibration of a two-dimensional ground-water-flow model, and (5) results of simulations of the effect of alternative ground-waterdevelopment schemes on ground-water levels and streamflow. The stream-aquifer system, consisting primarily of the Flat and Wood Rivers and the stratified-drift aquifer, is the principal subject of this report. The hydrogeologic interpretations in this report are based on data collected chiefly from May 1977 through June 1986; these data were supplemented by unpublished data on file at the U.S. Geological Survey office in Providence, Rhode Island that were collected in previous investigations by the USGS.

\section{Previous Studies}

Hydrogeologic information is available from earlier studies that include part or all of the study area. Surficial and bedrock geology have been mapped by Feininger (1962, 1965a, 1965b), Moore (1958, 1959, 1963), and Harwood and Goldsmith (1971a, 1971b). Reconnaissance studies on the availability of ground water were done by Bierschenk and Hahn (1959), Johnson and others (1960), Lang (1961), LaSala and Hahn (1960), Mason and Hahn (1960), and Randall and others $(1960,1966)$. A comprehensive quantitative study on the availability of ground water in the lower Pawcatuck River basin, which includes the upper Wood River ground-water reservoir, was completed by Gonthier and others (1974). Most of the data on which the present report 


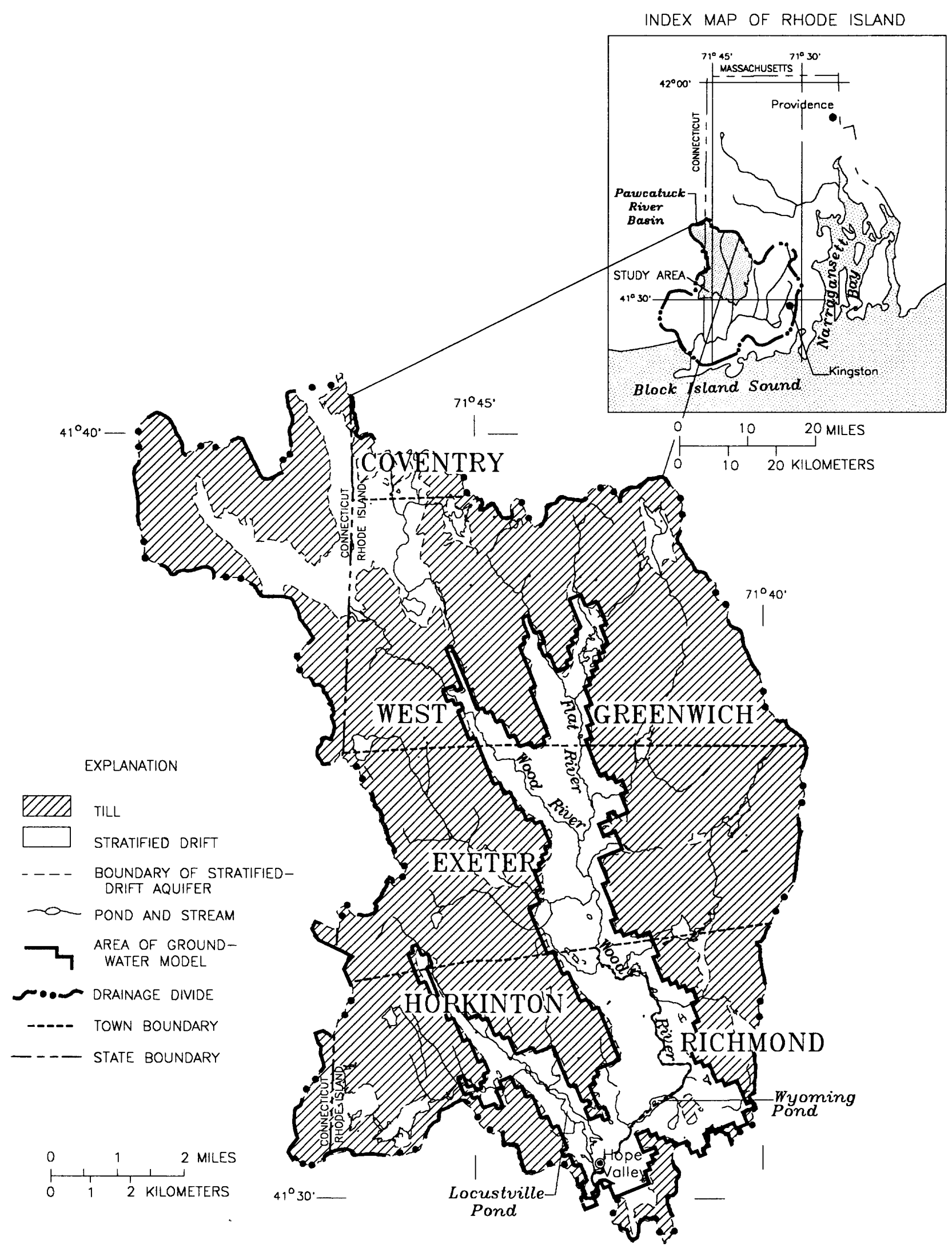

Figure 1.--Location and generalized hydrogeology of the upper Wood River study area in Rhode Island and the area represented by the ground-water model. 
is based are contained in a geohydrologic-dat a report by Dickerman and others (1989).

Additional hydrologic data for the upper Wood River ground-water reservoir area have been collected and continue to be collected by the USGS as part of the ongoing Pawcatuck River basin study. These data are contained in annual reports (U.S. Geological Survey, 1940-1950, 1951-1960, 1961-1964, 1965-1974, and 1975-1989). Data include records of discharge (1941-1989), and temperature and specific conductance (October 1977-1989) of the Wood River at Hope Valley, R.I. Data also include measurements of low streamflow at miscellaneous sites and records of water-level fluctuations in observation wells.

\section{Description and Location of Study Area}

The upper Wood River study area (fig. 2) is in southern Rhode Island and includes parts of the towns of Coventry, Exeter, Hopkinton, Richmond, and West Greenwich; it lies entirely within Washington County. It is about $12 \mathrm{mi}$ long and $7 \mathrm{mi}$ across at its widest point. The study area includes only that part of the drainage basin that lies within Rhode Island. The study area is crossed by the boundary between the New England Upland and the Seaboard Lowland sections of the New England physiographic province (Fenneman, 1938, pl. I).

The area is characterized by gently rolling topography (rounded hills and depressions), and the southward-trending Wood River and Flat River valleys (fig. 2). Between 90 and 95 percent of the study area is forested. The most rugged topography in the study area is at the southern end of Mount Tom, where nearly vertical cliffs of bedrock rise as much as $130 \mathrm{ft}$ above relatively flat land (Feininger, 1962).

The highest point in the study area is the summit of Bald Hill (elevation $629 \mathrm{ft}$ ) near the northeastern corner of the study area, and the lowest point is at the USGS streamflow-gaging station on the Wood River (elevation $68 \mathrm{ft}$ ) near the south-central edge of the study area at the basin outlet (fig. 2). Maximum relief within the 72.4- $\mathrm{mi}^{2}$ drainage area of the USGS station on the Wood River near Hope Valley is $561 \mathrm{ft}$. On the basis of available water-level data, the ground-water drainage divide and surface-water drainage divide are identical along the boundary of the study area.

\section{Approach}

Aquifer tests at 11 sites, lithologic logs from 146 test holes, and seismic-refraction data from 4 seismic refraction lines were used to determine the hydrogeology of the upper Wood River ground-water reservoir. Monthly water-level data from 37 observation wells and monthly stage data from 28 stream sites were used to prepare a long-term average water-table map. Water samples were collected from 20 stream sites, 11 aquifer-test wells, and selected test holes to assess the quality of surface and ground water. Data from 19 partial-record stations were used to estimate long-term average streamflow used in the stream model. A two-dimensional ground-water-flow model (MODFLOW) was used to evaluate the effects of simulated ground-water withdrawals on groundwater levels and streamflow for 10 development alternatives.

\section{Acknowledgments}

The authors express appreciation to the well drillers and area residents who provided information and helpful discussion concerning the geohydrology of the upper Wood River ground-water reservoir. Special acknowledgment is made to John H. Corey, Janet C. Hampton, Clifford and Virginia Woodmansee, and the Rhode Island Department of Environmental Management, Division of Forest Environment, who allowed aquifer tests to be conducted on their properties.

\section{GEOHYDROLOGIC SETTING}

This section describes the geology of the principal geologic units in the upper Wood River study area. Surface-water characteristics, water-table fluctuations, long-term average annual water budget, and 1989 ground-water withdrawals are discussed.

\section{General Geology}

The upper Wood River study area is underlain by three principal geologic units--bedrock, till, and stratified drift. These units differ significantly in geologic origin and water-yielding characteristics. The bedrock consists of crystalline rocks of igneous origin and partially metamorphosed sedimentary. rocks. Crystalline or metamorphosed bedrock un- 
derlies the entire drainage basin. The crystalline Hope Valley Alaskite Gneiss of Proterozoic age and the Scituate Granite Gneiss of Devonian age are the predominant bedrock units in the basin. Both of these bedrock units contain small inclusions of the Blackstone Group of Proterozoic age, the oldest rock unit in the study area. The Blackstone Group consists of interlayered schist and variably granitized gneiss. The Blackstone Group is mostly of sedimentary origin, though some layers may be of igneous origin. Overlying the bedrock are unconsolidated deposits of glacial origin.

During the Pleistocene Epoch, 1,610,000 to 10,000 BP (years before present), continental glaciers advanced from the north and covered this area several times. These glacial-ice sheets deposited rock debris, called "drift," which includes till, stratified drift, and scattered rock fragments. In the upper Wood River area, most of the glacial drift was deposited approximately 23,000 to 16,000 BP (Stone and Borns, 1986) during the advance and retreat of the last ice sheet of Wisconsin age. There is no sharp dividing line between till and stratified drift; one grades into the other.

Till, commonly called "hardpan" by well drillers, forms a generally thin, discontinuous mantle over the underlying bedrock and reflects bedrock topography in most places. Till consists of a mixture of material ranging in size from boulders to clay. Till covers about 73 percent of the study area, has an average thickness of about $25 \mathrm{ft}$, and reaches a maximum known thickness of $80 \mathrm{ft}$ (Bierschenk and Hahn, 1959).

The stratified drift consists of well-sorted layers of sand and gravel. The sand and gravel ranges in size from fine sand to cobble gravel, and individual grains are moderately to well rounded. Stratified drift covers about 27 percent of the study area and reaches a maximum known thickness of $156 \mathrm{ft}$. The stratified drift is the only geologic unit with materials sufficiently permeable to yield $0.5 \mathrm{Mgal} / \mathrm{d}$ or more of water for development. Feininger (1962) referred to the north-south-trending sand and gravel deposits of the Wood River valley and tributary valleys to the Wood River as the "western valley deposits."

The upper Wood River ground-water reservoir is an irregularly shaped body of porous, highly permeable stratified drift extending from Plain Road on the north to the streamflow-gaging station on the Wood River near Hope Valley on the south (fig. 2). The ground-water reservoir ranges in width from about $4,000 \mathrm{ft}$ to $9,000 \mathrm{ft}$, and it has an areal extent of about $8 \mathrm{mi}^{2}$. Because a large part of the groundwater reservoir is within the Arcadia State Park
Management Area, ground water within this area is less vulnerable to contamination than most areas studied by the USGS in its cooperative program with the RIWRB.

\section{Surface Water}

The Flat and Wood Rivers and their main tributaries are the principal areas of ground-water discharge from the stratified-drift aquifer. Continuous records of streamflow have been collected since 1942 at a USGS gaging station (01118000) on the Wood River at Hope Valley, and since 1963 at a USGS gaging station (01117800) on the Wood River near Arcadia (fig. 2). Long-term average annual runoff from the basin was determined from a 48-year period of record. From 1942 through 1989, long-term annual runoff from the basin averaged $157 \mathrm{ft}^{3} / \mathrm{s}(101$ $\mathrm{Mgal} / \mathrm{d})$ at the Hope Valley streamflow-gaging station on the Wood River. Long-term average annual runoff from the northern part of the basin for 1942-89 was estimated to average $76.0 \mathrm{ft}^{3} / \mathrm{s}(49.1 \mathrm{Mgal} / \mathrm{d})$ at the Arcadia streamflow-gaging station on the Wood River. This estimate was determined by multiplying the drainage area above the Arcadia station (35.2 $\left.\mathrm{mi}^{2}\right)$ by the long-term flow $\left(2.16 \mathrm{ft}^{3} / \mathrm{s} / \mathrm{mi}^{2}\right)$ at the Hope Valley station.

Long-term average annual runoff was estimated at partial-record stations on Factory Brook, Phillip Brook, and Breakheart Brook (main tributaries to the Flat River); Kelly Brook, Parris Brook, Roaring Brook, and Baker Brook (main tributaries to the Wood River); and Brushy Brook and Moscow Brook (tributaries to Locustville Pond). The estimate at each partial-record station was made using an empirical relation determined from concurrent discharges at the site and a long-term streamflow-gaging station in the basin. These estimates are given in table 1. Estimates of long-term average annual runoff at partialrecord stations were used in the ground-water-flow model discussed later in this report. Locations of partial-record stations are shown in figure 2.

The duration of flow for a stream can be shown by means of a cumulative frequency curve called a flow-duration curve. Flow-duration curves for the Wood River at the Arcadia and Hope Valley stations are shown in figure 3. Streamflow on the high-discharge part of the curves is largely stormwater runoff, whereas that on the low-discharge part is mainly ground-water runoff. In Rhode Island, the minimum flow for which streamwater-quality standards have been developed is the minimum average daily flow for 7 consecutive days that can be expected to occur on 


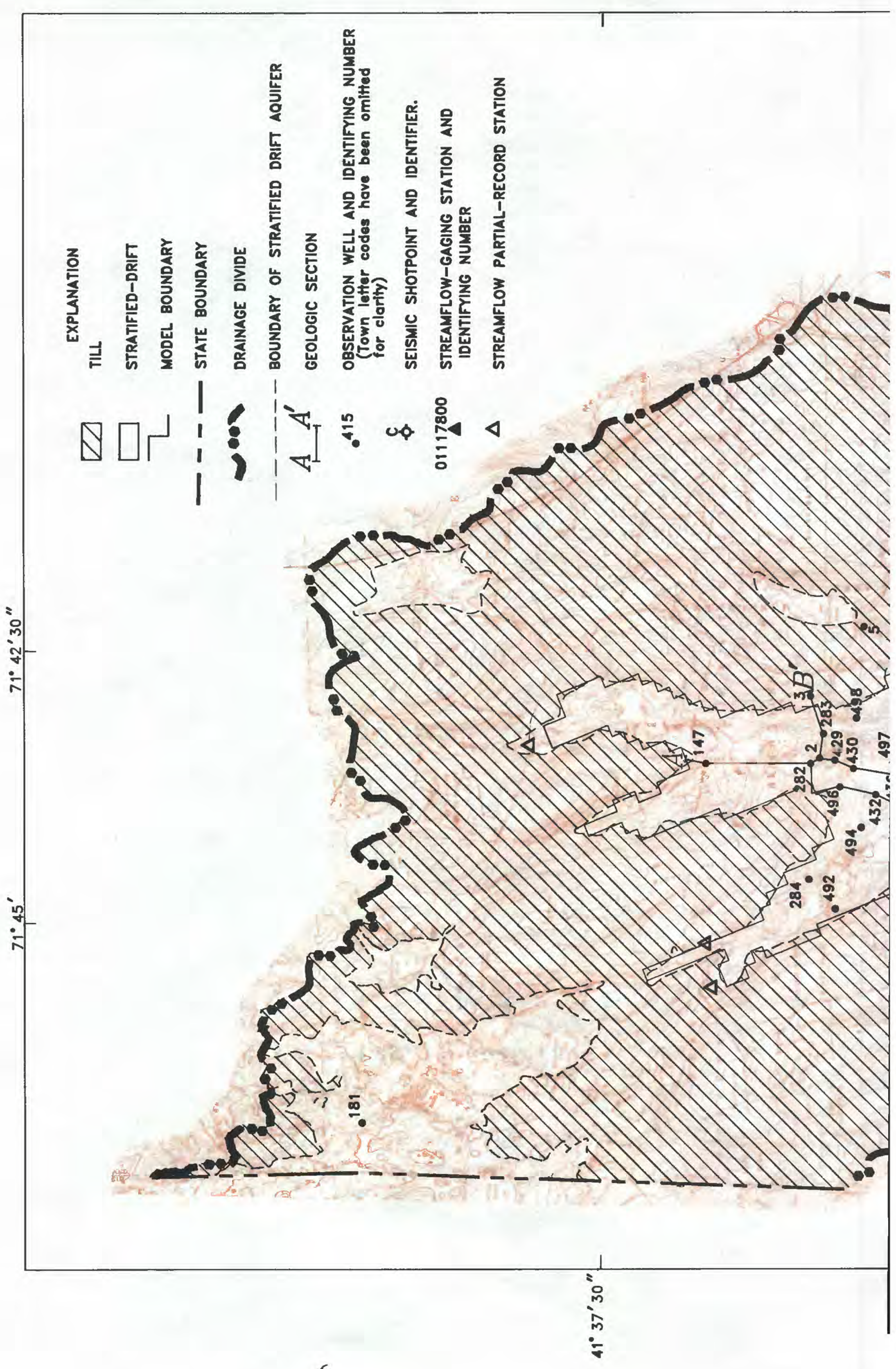




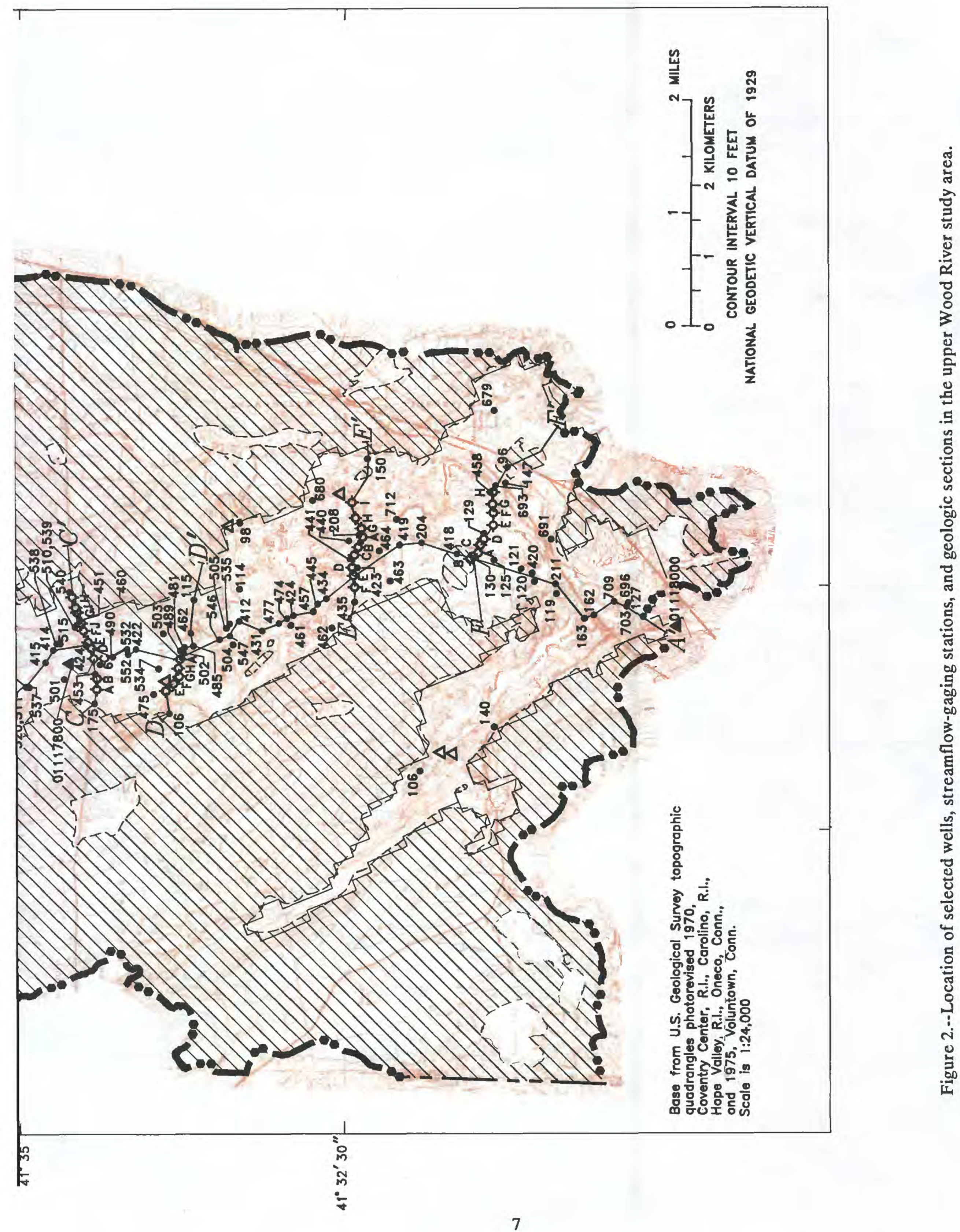


Table 1.--Estimated long-term average annual runoff at partial-record stations [ $\mathrm{ft}^{3} / \mathrm{s}$, cubic feet per second; Mgal/d, million gallons per day]

\begin{tabular}{lcc} 
& Station name & \multicolumn{2}{c}{ Runoff } \\
\cline { 2 - 3 } & \multicolumn{1}{c}{$\mathbf{f t}^{3} / \mathrm{s}$} & Mgal/d \\
\hline Factory Brook & 3.5 & 2.3 \\
Phillip Brook $^{1}$ & 2.0 & 1.3 \\
Breakheart Brook $^{*}$ & 20.0 & 12.9 \\
Kelly Brook & 12.0 & 7.8 \\
Wood River & 23.0 & 14.7 \\
Parris Brook & 21.0 & 13.6 \\
Roaring Brook & 25.0 & 16.2 \\
Baker Brook & .20 & .13 \\
Brushy Brook & 9.0 & 5.8 \\
Moscow Brook & 8.0 & 5.2 \\
\hline
\end{tabular}

${ }^{1}$ Long-term average annual runoff estimated from data collected at other partial-record stations in the study area.

the average once in 10 years $^{2}$ (Rhode Island Statewide Planning Program and Rhode Island Department of Health, 1976, p. A-7). A relation developed by Johnston and Dickerman (1985, table 2) for streams at three long-term streamflow-gaging stations in the Pawcatuck River basin for water years 1942 through 1978 equates the $7 Q 10$ to the 99.1-percent flow duration. The 99.1-percent flow duration of streamflow leaving the study area at Hope Valley is $20.2 \mathrm{ft}^{3} / \mathrm{s}(13.1 \mathrm{Mgal} / \mathrm{d})$, and the $7 \mathrm{Q} 10$ flow is 20.4 $\mathrm{ft}^{3} / \mathrm{s}(13.2 \mathrm{Mgal} / \mathrm{d})$.

\section{Ground Water}

The stratified-drift aquifer in the upper Wood River ground-water reservoir is unconfined. Locally, however, some parts of the stratified-drift aquifer may be semiconfined by fine-grained materials (Gonthier and others, 1974).

A map showing the configuration and altitude of the water table in the stratified-drift aquifer was prepared from water levels measured in 37 observation wells primarily during December 1982 when streamflow and water levels were near long-term
(1942-89) average annual conditions (fig. 4). All observation wells were screened or open to the aquifer at the water table. The direction of ground-water flow in the aquifer is from the till uplands toward the Flat and Wood Rivers. Water-level measurements, made in multilevel piezometers at aquifer-test sites, indicate that ground-water flow is predominantly horizontal.

The altitude of the water table fluctuates several feet seasonally. Hydrographs of monthly water-table fluctuations in wells in stratified drift and till are shown in figure 5. The range in fluctuations of the water table is affected by the rates of recharge to and discharge from the aquifer, which in turn are affected by many factors, including type of aquifer material and depth to the water table. Stratified drift has higher recharge and discharge rates than till because the higher hydraulic conductivity and effective porosity of the stratified-drift material permit more rapid movement of ground water. Because ground water moves through stratified drift more rapidly than through till, the water table in stratified drift has a smaller range of fluctuation than the water table in till. For example, the range in water-table fluctuation for the period June 1982 through October 1985 is

2 The 7-day low flow with a 10-year recurrence interval is referred to in this report as the 7Q10. 


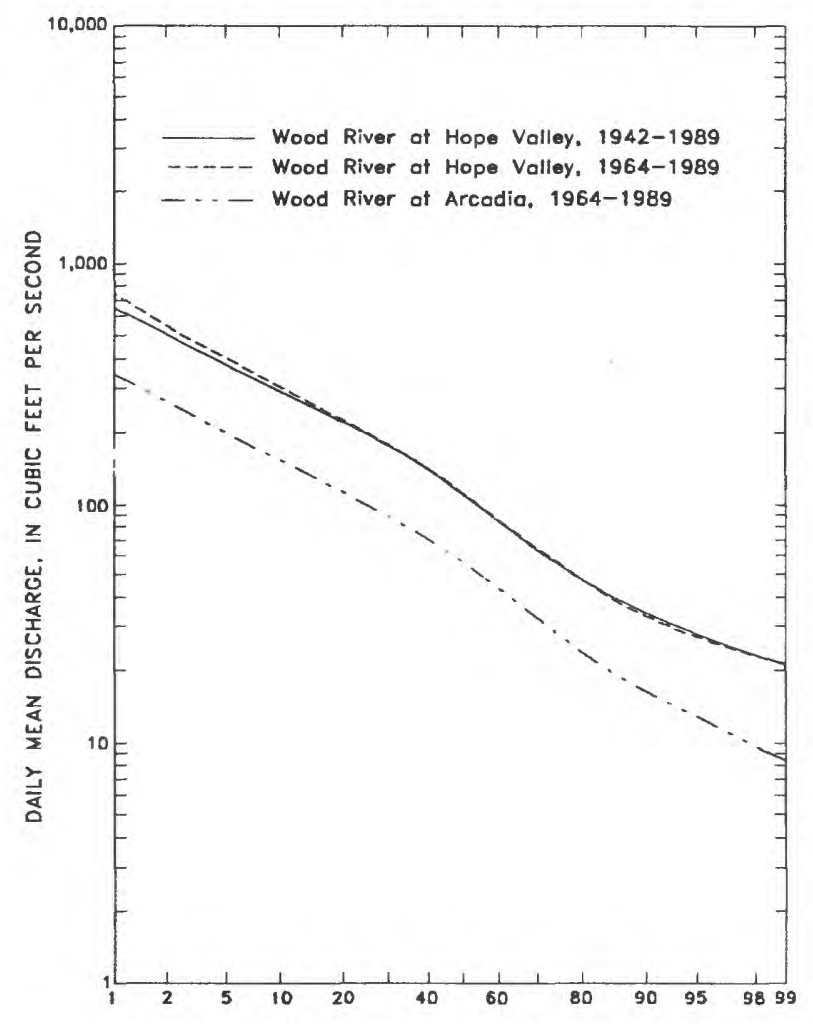

PERCENTAGE OF TIME DISCHARGE WAS EQUALED OR EXCEEDED

Figure 3.--Duration of daily mean stream discharge of the Wood River at Arcadia and at Hope Valley.

$3.7 \mathrm{ft}$ in the stratified drift well HOW (Hopkinton well) 461 (fig. 5A) and is $5.6 \mathrm{ft}$ in the till well EXW (Exeter well) 5 (fig. 5B).

Ground-water levels in wells, shown in figure 5, fluctuate in annual cycles. Generally, ground-water levels decline from mid-spring to mid-fall because most precipitation is returned to the atmosphere by evaporation and transpiration before it reaches the water table. From mid-fall to mid-spring, lower rates of evaporation and transpiration allow more precipitation to percolate to the water table, which results in generally higher water levels. An example of a typical annual cycle is shown in figure $5 \mathrm{~A}$ for the period April 1983 through March 1984.

A shallow water table generally receives recharge more rapidly than a deep water table; this difference results in a large range of fluctuations in the shallow water table. For example, during June 1982 through October 1985, the shallow water table at HOW 461 (fig. 5A) fluctuated $3.7 \mathrm{ft}$, whereas the deep water table at EXW 495 (fig. 5C) fluctuated $3.0 \mathrm{ft}$.

The relation between the ground-water level in an observation well and stream discharge in a nearby river is shown in figure 5D. The two fluctuate similarly because of their proximity $(150 \mathrm{ft})$ and because the hydraulic connection between the aquifer and the stream is good. Decreased ground-water runoff during low ground-water conditions in EXW $6(6.8 \mathrm{ft}$ below LSD (land-surface datum)) in September 1983 produced low flow $\left(13 \mathrm{ft}^{3} / \mathrm{s}\right)$ in the Wood River. Increased ground-water runoff during high groundwater conditions in EXW 6 (2.6 ft below LSD) in April 1983 produced high flow $\left(330 \mathrm{ft}^{3} / \mathrm{s}\right)$ in the Wood River.

\section{Basin Water Budget}

During 1942-89, annual precipitation at the $\mathrm{Na}$ tional Oceanic and Atmospheric Administration station at Kingston, R.I. (10 mi southeast of the upper Wood River study area), ranged from 30.69 in. (in 1965) to $70.21 \mathrm{in.} \mathrm{(in} \mathrm{1983)} \mathrm{and} \mathrm{averaged} 47.58 \mathrm{in}$. Annual precipitation and departure from average precipitation at Kingston during 1942-89 are shown in figures $6 \mathrm{~A}$ and $6 \mathrm{~B}$, respectively. The 1963-66 drought period depicted in figures $6 \mathrm{~A}$ and $6 \mathrm{~B}$ represents the lowest 4 consecutive annual precipitation values recorded at the National Weather Service Station at Kingston since the station began operation in 1889.

Total runoff from the streamflow-gaging station on the Wood River at Hope Valley from 1942 through 1989 ranged from 15.96 in. (in 1966) to $47.64 \mathrm{in}$. (in 1979) and averaged 29.31 in. Annual runoff and departure from average runoff "of the Wood River at the Hope Valley station from 1942 through 1989 are shown in figures $6 \mathrm{C}$ and $6 \mathrm{D}$. At the station, underflow (ground-water outflow) from the basin is estimated to be $1 \mathrm{Mgal} / \mathrm{d}$ (table 2). Underflow was estimated from the transmissivity, water-table gradient, and width of the stratified-drift valley at the Hope Valley station.

Evaporation and transpiration in the upper Wood River study area were estimated to be 62 $\mathrm{Mgal} / \mathrm{d}$ (table 2). Evaporation and transpiration were calculated as the difference between the total precipitation at Kingston, R.I., and the long-term average annual total runoff of the Wood River, plus estimated underflow at the Hope Valley streamflowgaging station. On the basis of table 2, evaporation and transpiration equal 37.8 percent of precipitation. For comparison, evaporation and transpiration in the 


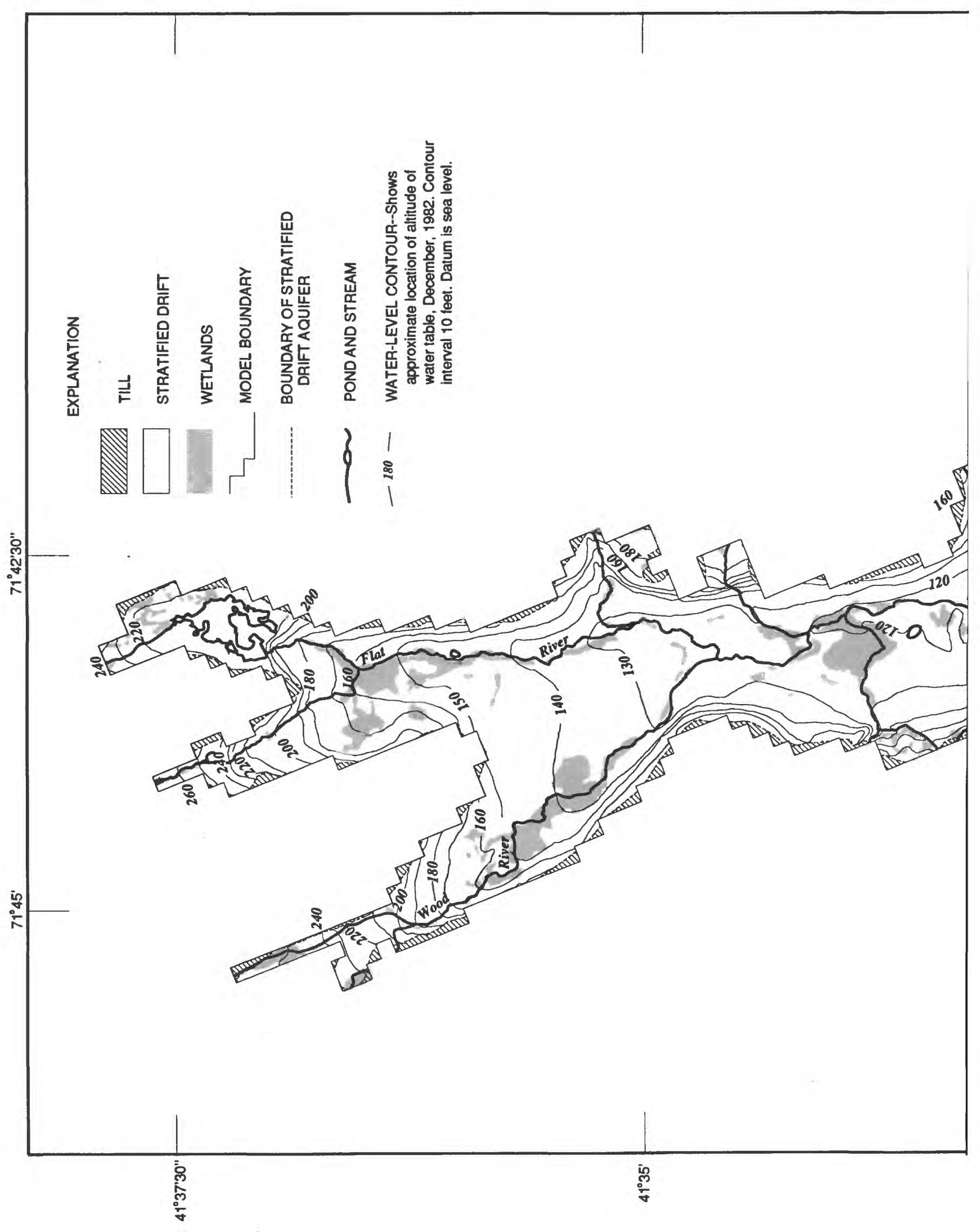




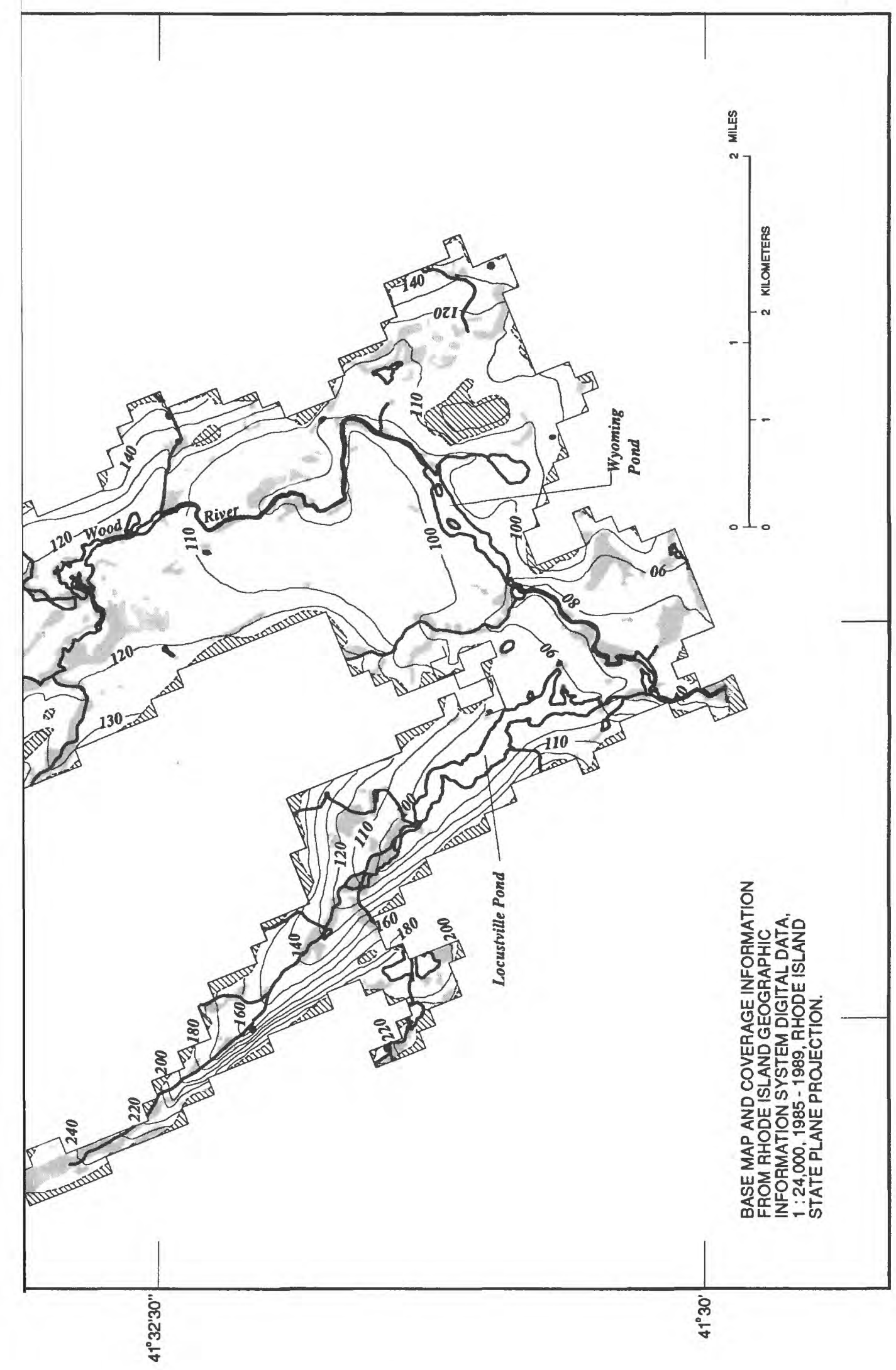

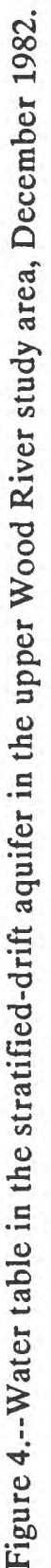




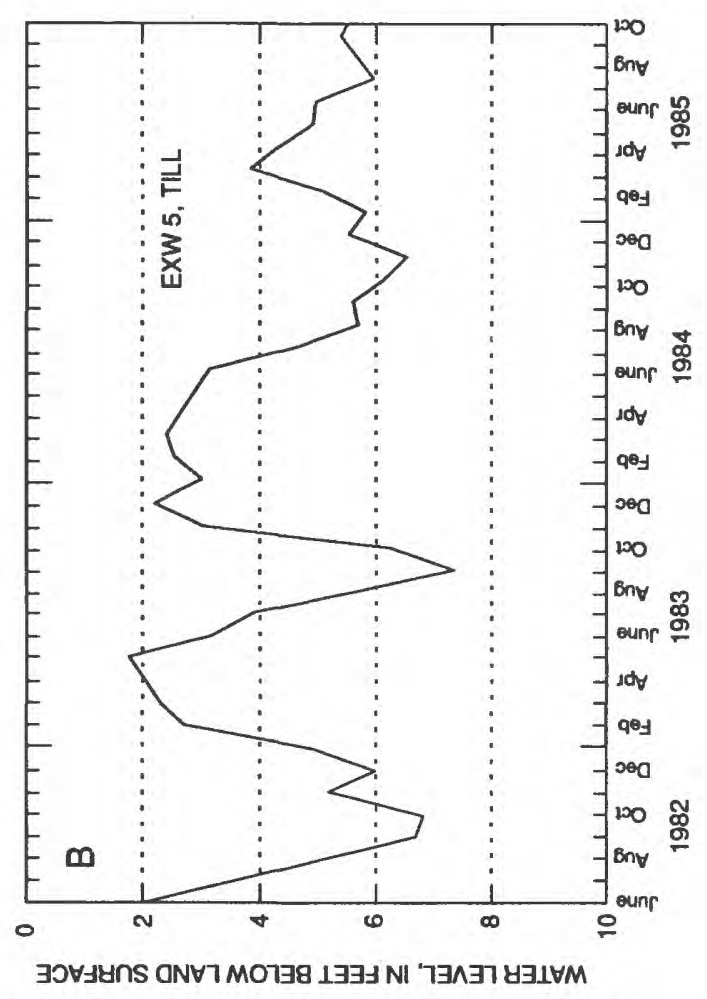

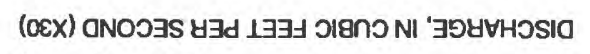
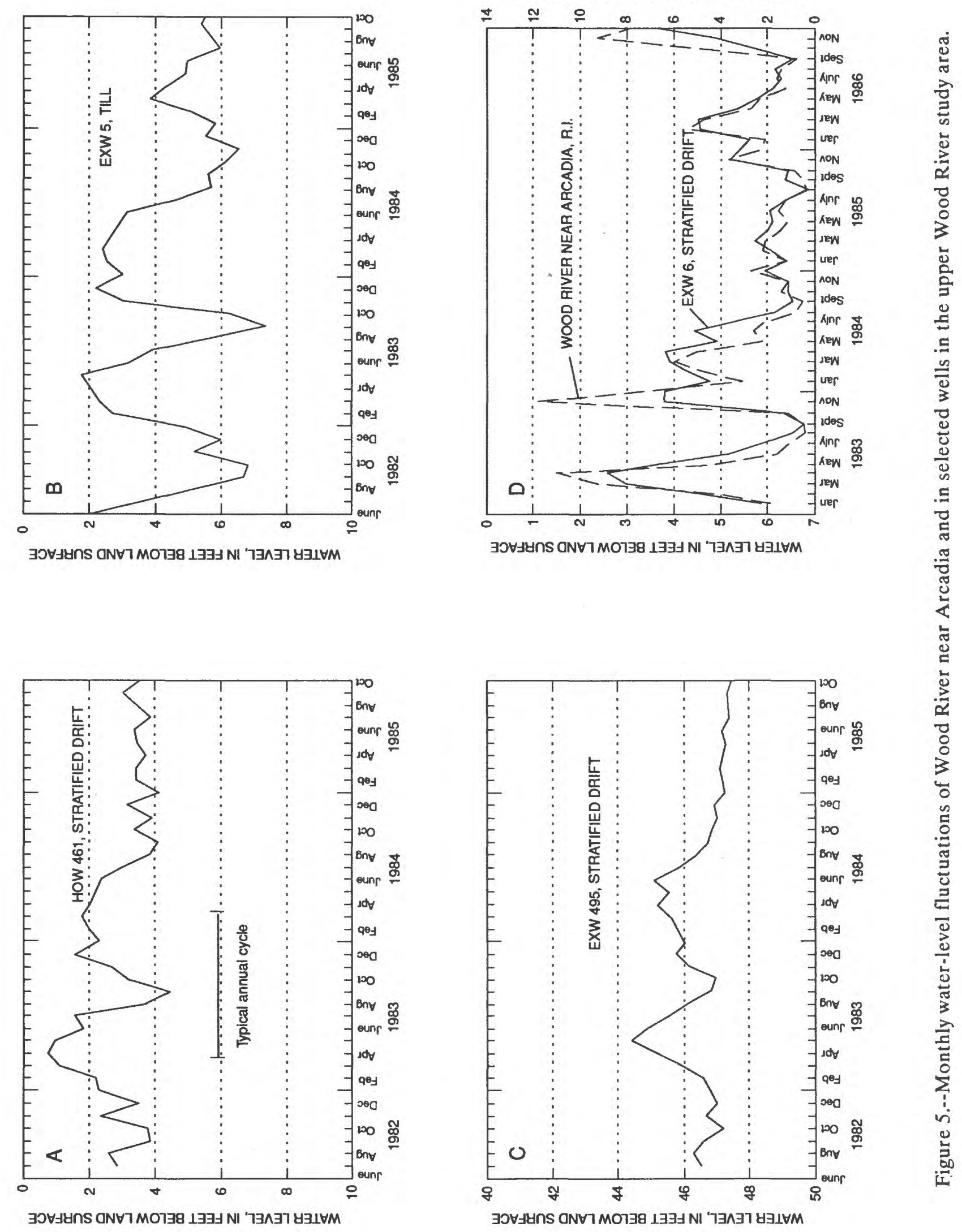

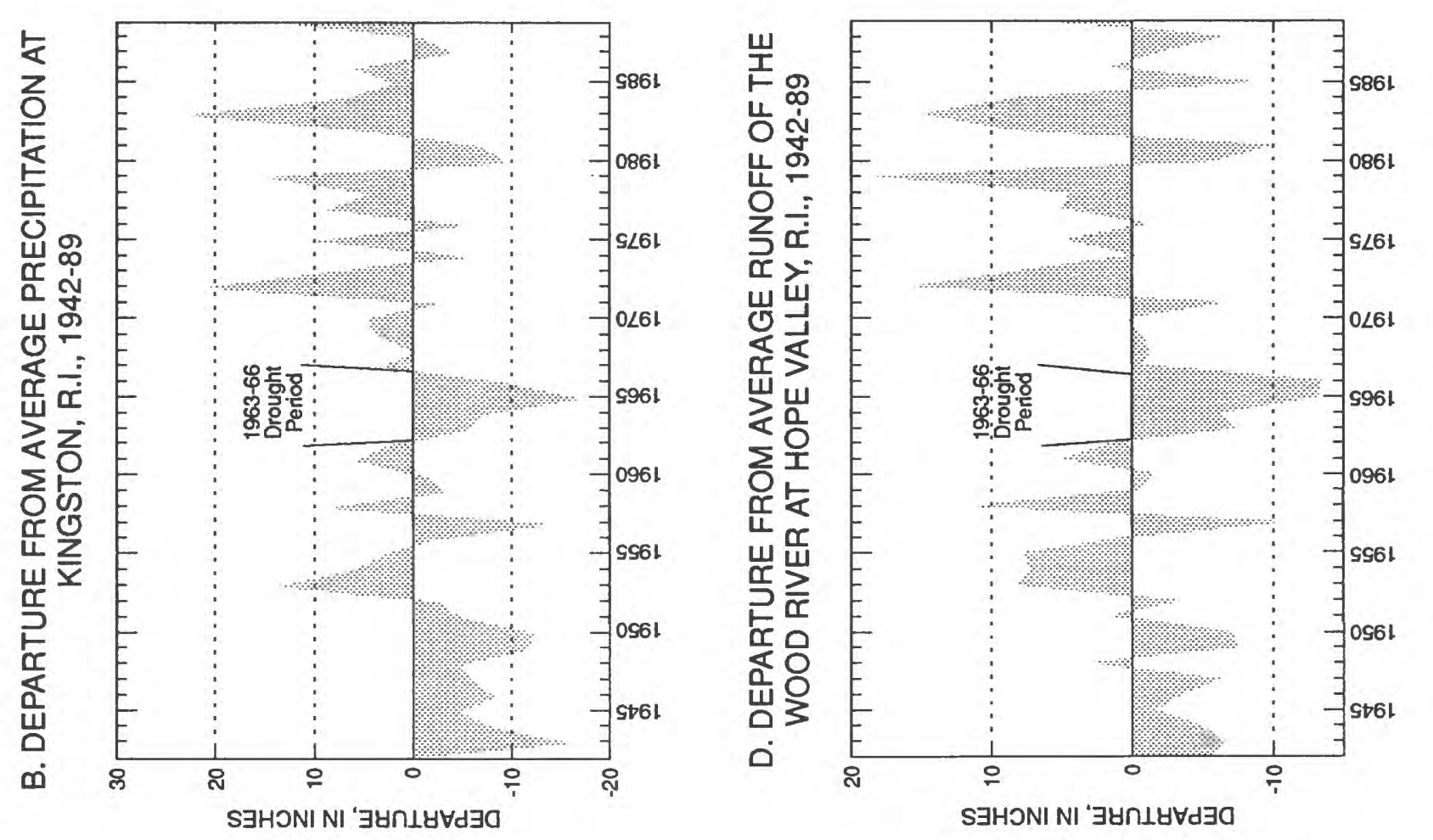

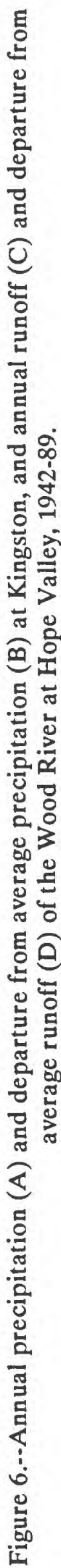
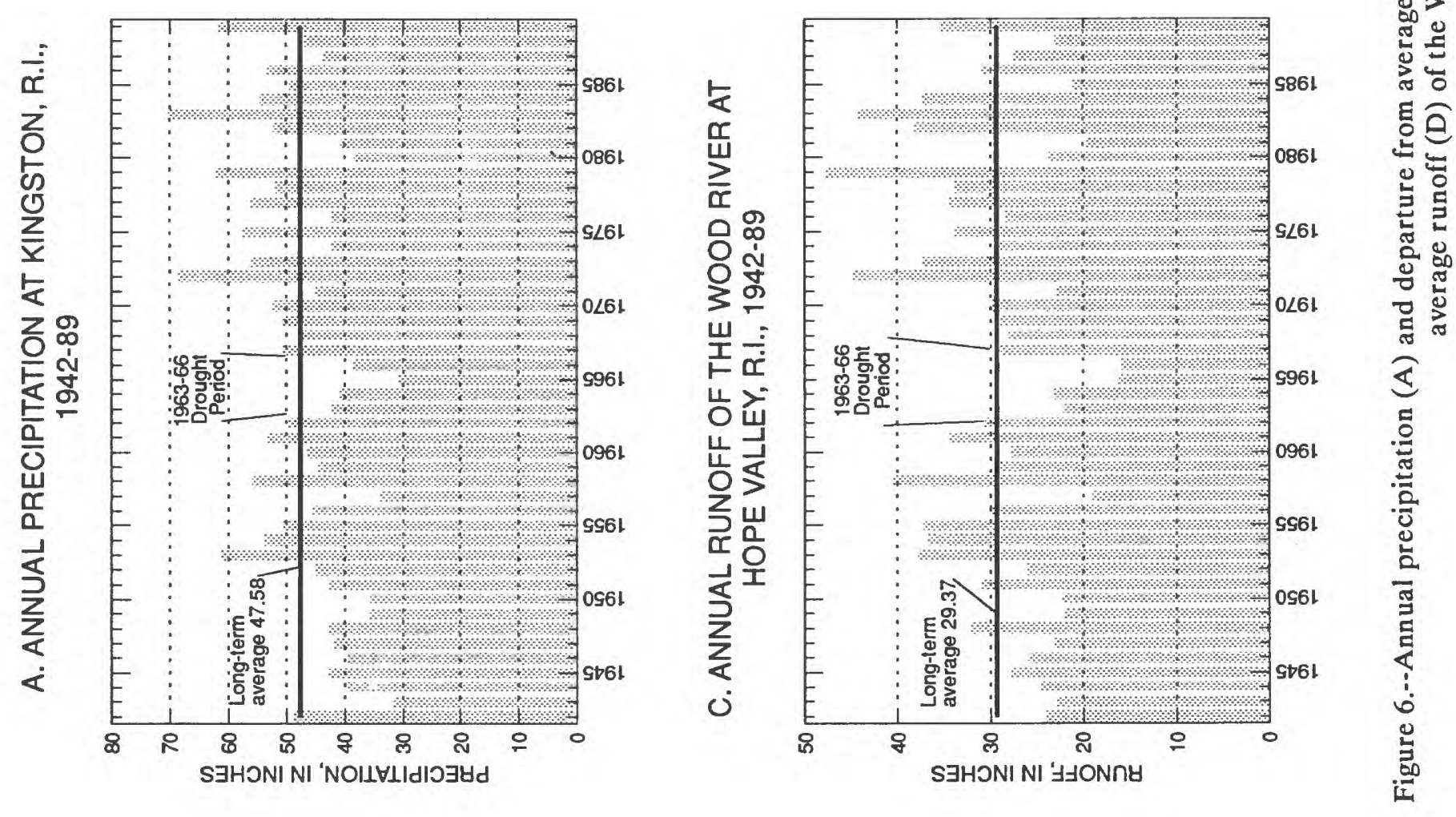
Table 2.--Long-term average annual water budget (1942-89)

[Mgal/d, million gallons per day; $(\mathrm{Mgal} / \mathrm{d}) / \mathrm{mi}^{2}$, million gallons per day per square mile]

\begin{tabular}{|c|c|c|c|}
\hline Inflow & $\mathrm{Mgal} / \mathrm{d}$ & Outflow & $\mathrm{Mgal} / \mathrm{d}$ \\
\hline \multirow[t]{3}{*}{ Precipitation $^{1}$} & 164 & $\begin{array}{l}\text { Total runoff from the } \\
\text { Wood River area } \\
\text { upstream from the } \\
\text { Hope Valley gage } \\
\left(72.4 \mathrm{mi}^{2}\right)\end{array}$ & 101 \\
\hline & & $\begin{array}{l}\text { Underflow at } \\
\text { Hope Valley gage }\end{array}$ & 1 \\
\hline & & $\begin{array}{c}\text { Evaporation and } \\
\text { transpiration }^{4}\end{array}$ & 62 \\
\hline Total & 164 & & 164 \\
\hline
\end{tabular}

${ }^{1}$ Based on long-term average annual precipitation (47.6 inches) at Kingston, R.I., $1942-89$.

${ }^{2}$ Based on long-term average annual runoff $\left(1.40(\mathrm{Mgal} / \mathrm{d}) / \mathrm{mi}^{2}\right)$ of the Wood River at Hope Valley, R.I., streamflowgaging station, 1942-89.

${ }^{3}$ Underflow estimated from the transmissivity, water-table gradient, and length-of-flow cross section at the Hope Valley streamflow-gaging station.

${ }^{4}$ Difference between total precipitation at Kingston, R.I., and long-term average annual total runoff of the Wood River at Hope Valley, R.I., 1942-89, plus estimated underflow at the streamflow-gaging station.

lower Wood River study area amount to 40 percent of precipitation.

Water enters the upper Wood River study area as precipitation and leaves the study area as surface outflow from the Wood River at the Hope Valley streamflow-gaging station, as underflow at the station, and as evaporation and transpiration. A water budget quantitatively expresses the balance of water in the study area, and can be expressed as inflow equals outflow, plus or minus changes in storage. Over many years, the net changes in storage tend to be small and can be considered negligible. Thus, the water-budget equation for the study area is expressed as follows:

$$
\begin{gathered}
\text { INFLOW }=\text { OUTFLOW } \\
\text { P }=\mathrm{Rt}_{\text {out }}+\mathrm{U}+\mathrm{ET} \\
164=101+1+62
\end{gathered}
$$

where

$$
\begin{aligned}
& \mathbf{P} \text { is precipitation, in } \mathrm{Mgal} / \mathrm{d} \text {; } \\
& \mathrm{Rt}_{\text {out }} \text { is total runoff out of the study area, } \\
& \text { in } \mathrm{Mgal} / \mathrm{d} \text {; } \\
& \mathrm{U} \text { is underflow, in } \mathrm{Mgal} / \mathrm{d} \text {, and; } \\
& \mathrm{ET} \text { is evaporation and transpiration, in } \\
& \mathrm{Mgal} / \mathrm{d} \text {. }
\end{aligned}
$$

\section{Water Use}

Ground-water withdrawals during 1989 averaged about $0.34 \mathrm{Mgal} / \mathrm{d}$. Domestic wells accounted for about 92 percent $(0.31 \mathrm{Mgal} / \mathrm{d})$ of the ground water withdrawn during $1989^{3}$, and the Richmond Water Department (the largest single water user in the study area in 1989) accounted for about 6 percent $(0.02 \mathrm{Mgal} / \mathrm{d})$ of the withdrawals. Combined ground-

\footnotetext{
${ }^{3}$ Estimates of domestic pumpage were based on 1,282 houses with 4 persons per household times 60 gallons per day per person.
} 
water pumpage from other sources, such as the Hopkinton elementary school, the State garage in Hope Valley, and seasonal camping facilities, was about 2 percent $(0.01 \mathrm{Mgal} / \mathrm{d})$ of the withdrawals.

No public sewage-treatment facilities were operating in the study area in 1989. Most water withdrawn from wells was returned to the ground through individual sewage-disposal systems and, therefore, most was available for reuse downgradient in the basin. The amount of water lost to evaporation and transpiration through individual sewage disposal-systems was not determined, but it is probably less than 10 percent.

\section{HYDROGEOLOGY}

Hydrogeologic information is critical to developing an understanding of the ground-water-flow system in the study area. The hydrogeology of the stratified drift, bedrock, and till aquifers is described in the following sections.

\section{Stratified-Drift Aquifer}

Permeable deposits of stratified drift form the major aquifer in the upper Wood River study area. The drift covers 27 percent of the study area and reaches a maximum known thickness of $156 \mathrm{ft}$. The drift consists of layers of sorted gravel and sand interbedded with minor amounts of silt and clay.

The stratified-drift aquifer is the only aquifer in the study area capable of producing well yields of 0.5 $\mathrm{Mgal} / \mathrm{d}$ or more. The aquifer is unconfined and is in hydraulic connection with perennial streams and ponds. Well yields in the stratified-drift aquifer depend on the natural recharge to the aquifer, the hydraulic properties of the aquifer, and the degree of stream-aquifer interconnection.

The bedrock surface in the upper Wood River study area is shown in figure 7 , and the water table, lithology, and thickness of the stratified-drift deposits are shown in a series of generalized geologic sections (figs. 8-13). Seismic-refraction surveys were used to help determine depth to water and depth to bedrock. All well and seismic shotpoint locations used in geologic sections are shown in figure 2.
Geologic section A-A', parallel to the valley axis (fig. 8 ), shows the complex interbedding and lithologic heterogeneity of this aquifer.

Geologic sections through the Wood River valley show depth to water and bedrock and give a generalized lithologic picture of the material buried in the preglacial valley. Locations of geologic sections are shown in figure 2. Geologic section B-B' (fig. 9) shows the northern part of the valley; sections C-C' (fig. 10), D-D' (fig. 11), and E-E' (fig. 12) show the central parts of the valley; and section F-F' (fig. 13) shows the southern part of the valley.

From Plain Road south to Wyoming (fig. 2), the Wood River valley is more than $1 \mathrm{mi}$ wide and the stratified drift is moderately thick ( 60 to $80 \mathrm{ft}$ ). The Wood River valley narrows to less than $0.4 \mathrm{mi}$ at Wyoming where bedrock outcrops are exposed in the floodplain and on adjacent till uplands. South of Wyoming, the valley widens again to almost $1 \mathrm{mi}$, but narrows to $0.15 \mathrm{mi}$ at the southern boundary of the study area at the Hope Valley streamflow-gaging station. The maximum known saturated thickness of the stratified-drift aquifer is about $125 \mathrm{ft}$ at well EXW 462 on the eastern side of Deep Pond. The saturated thickness of the aquifer averages about $70 \mathrm{ft}$ in most of the study area.

The water-table and bedrock maps (figs. 4 and 7) were drawn from data collected at wells and seismic-refraction surveys shown in figure 2 . These maps were digitized and used to produce the saturatedthickness map (fig. 14). The computer-generated saturated-thickness map was checked at 93 well sites to verify that the map was an accurate representation of the aquifer. Computer-generated saturated thickness is within $5 \mathrm{ft}$ of values obtained from well data at most of the 93 sites.

Well HOW 477 (Hopkinton well), an 8-in. test well ${ }^{4}$, produced the highest well yield measured for the stratified-drift aquifer, at $713 \mathrm{gal} / \mathrm{min}$. HOW 477 was located on the western side of the buried preglacial valley, about $250 \mathrm{ft}$ west of the Wood River (fig. 2).

\section{Aquifer Characteristics and Hydraulic Properties}

Drawdown/recovery data for 11 aquifer tests done primarily between December 1980 and June

\footnotetext{
${ }^{4}$ Well sizes mentioned in this report are nominal inside diameters.
} 


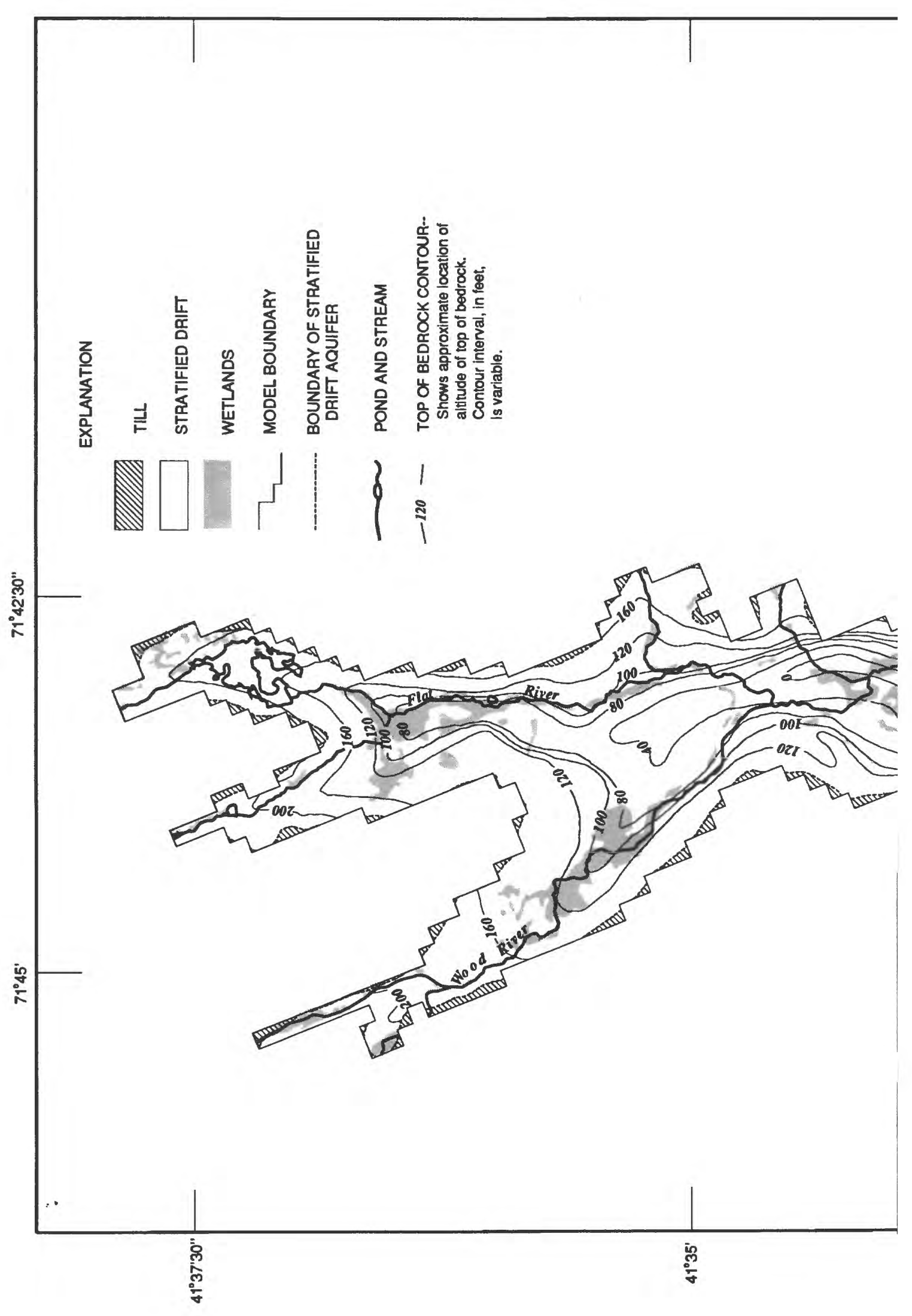




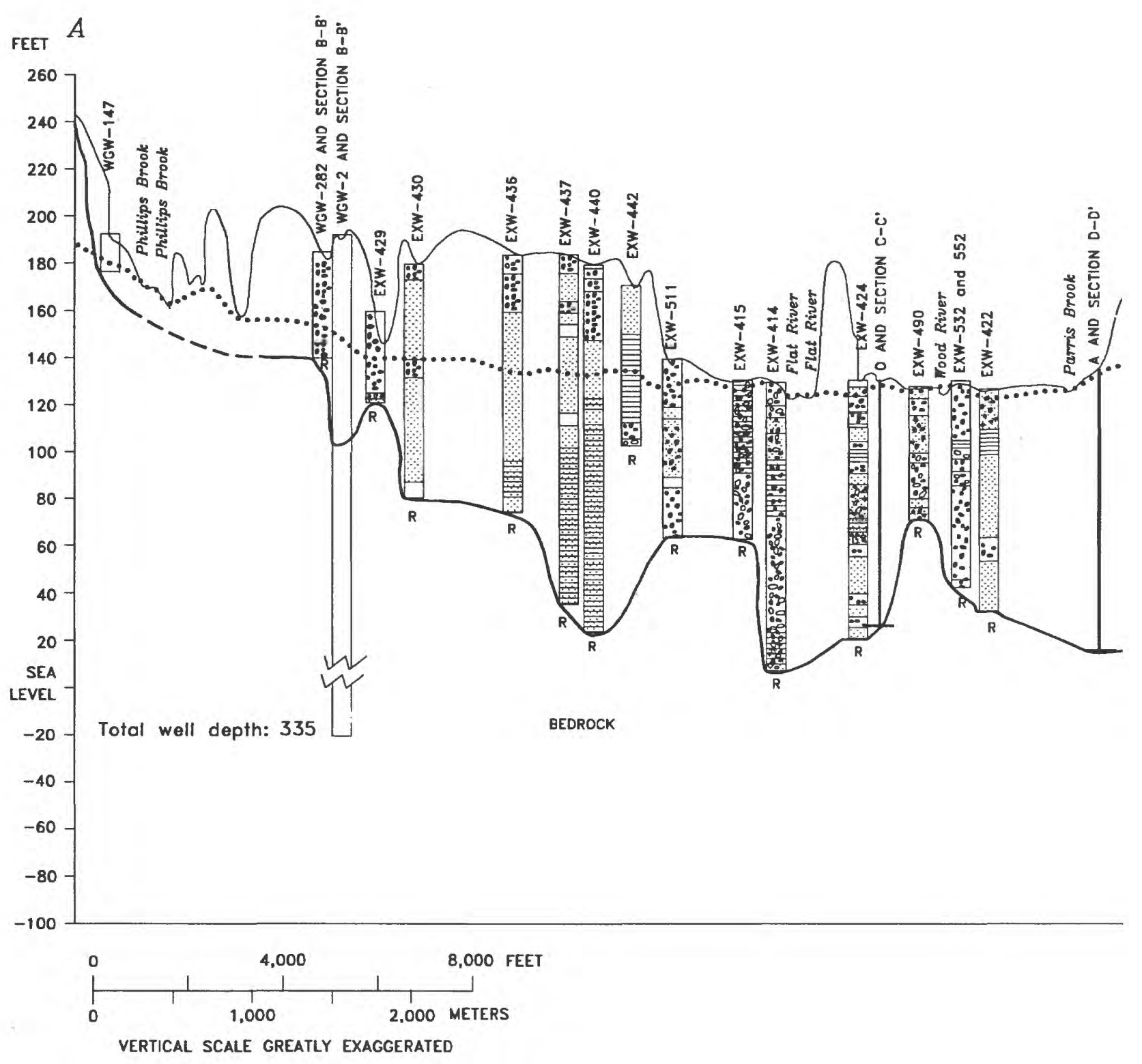

Figure 8.--Geologic section (A-A') of the (section trace shown 


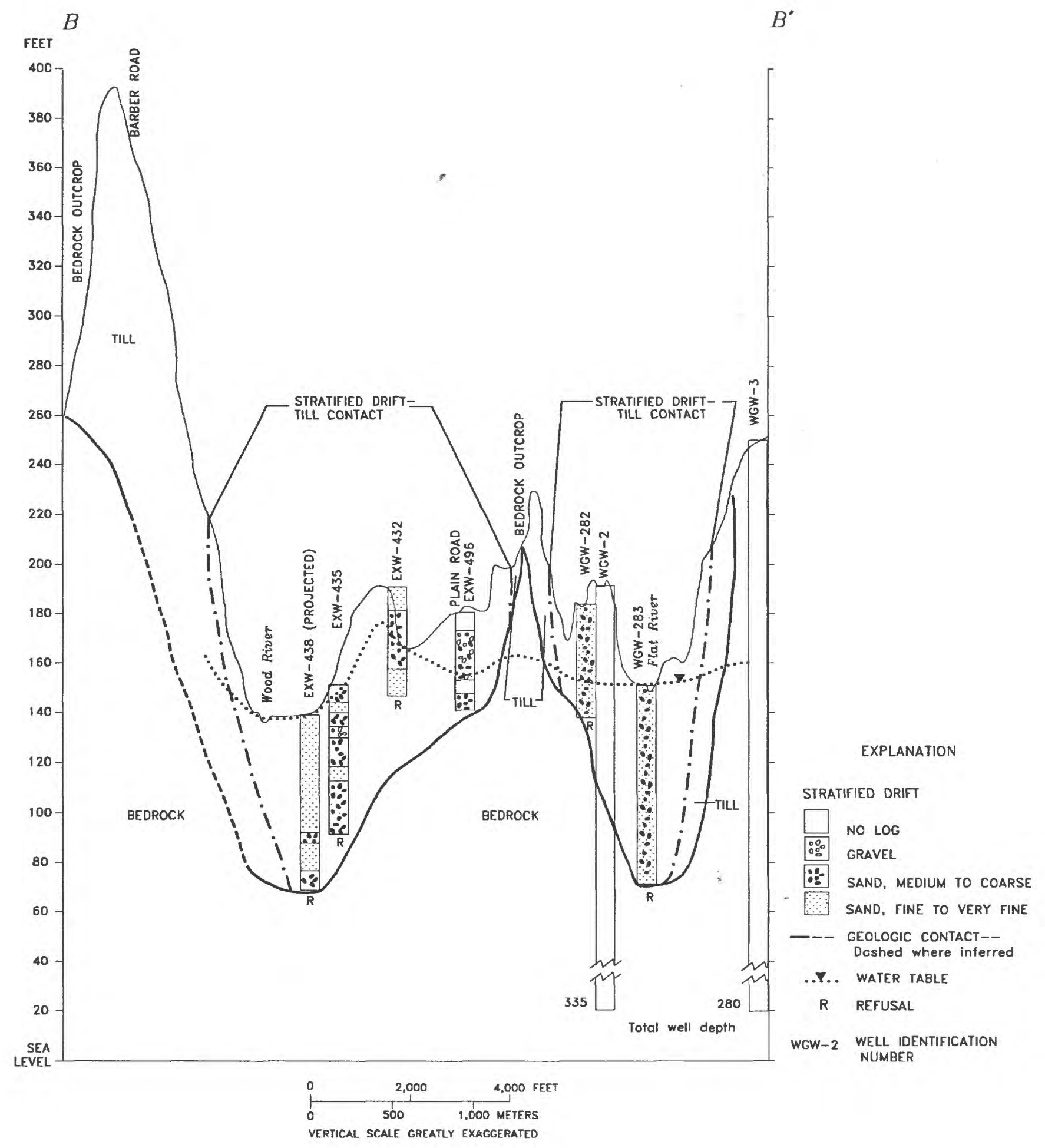

Figure 9.--Generalized geologic section B-B'near Plain Road (section trace shown in figure 2). 


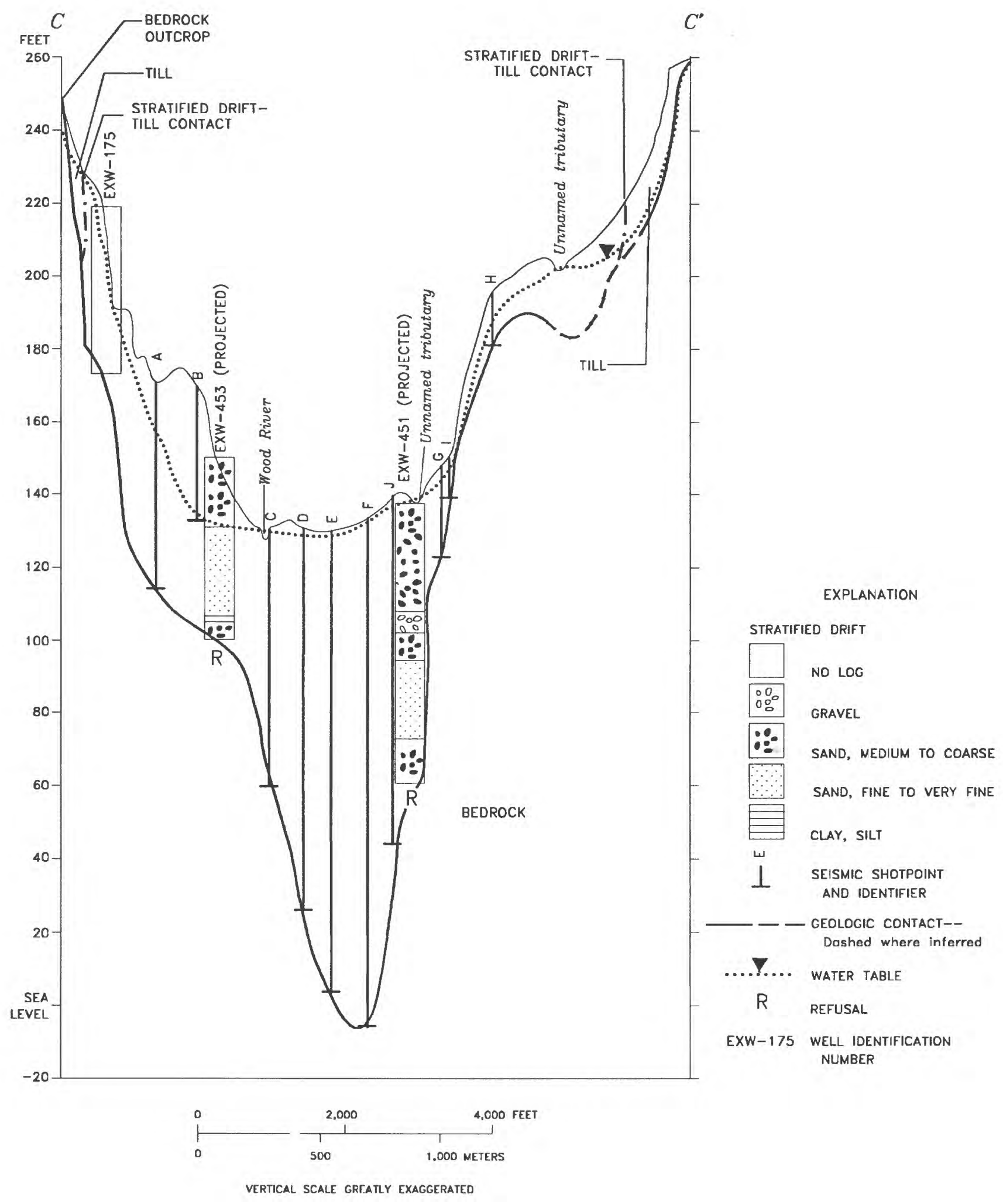

Figure 10.--Generalized geologic section C-C' along State Highway 165 (section trace shown in figure 2). 


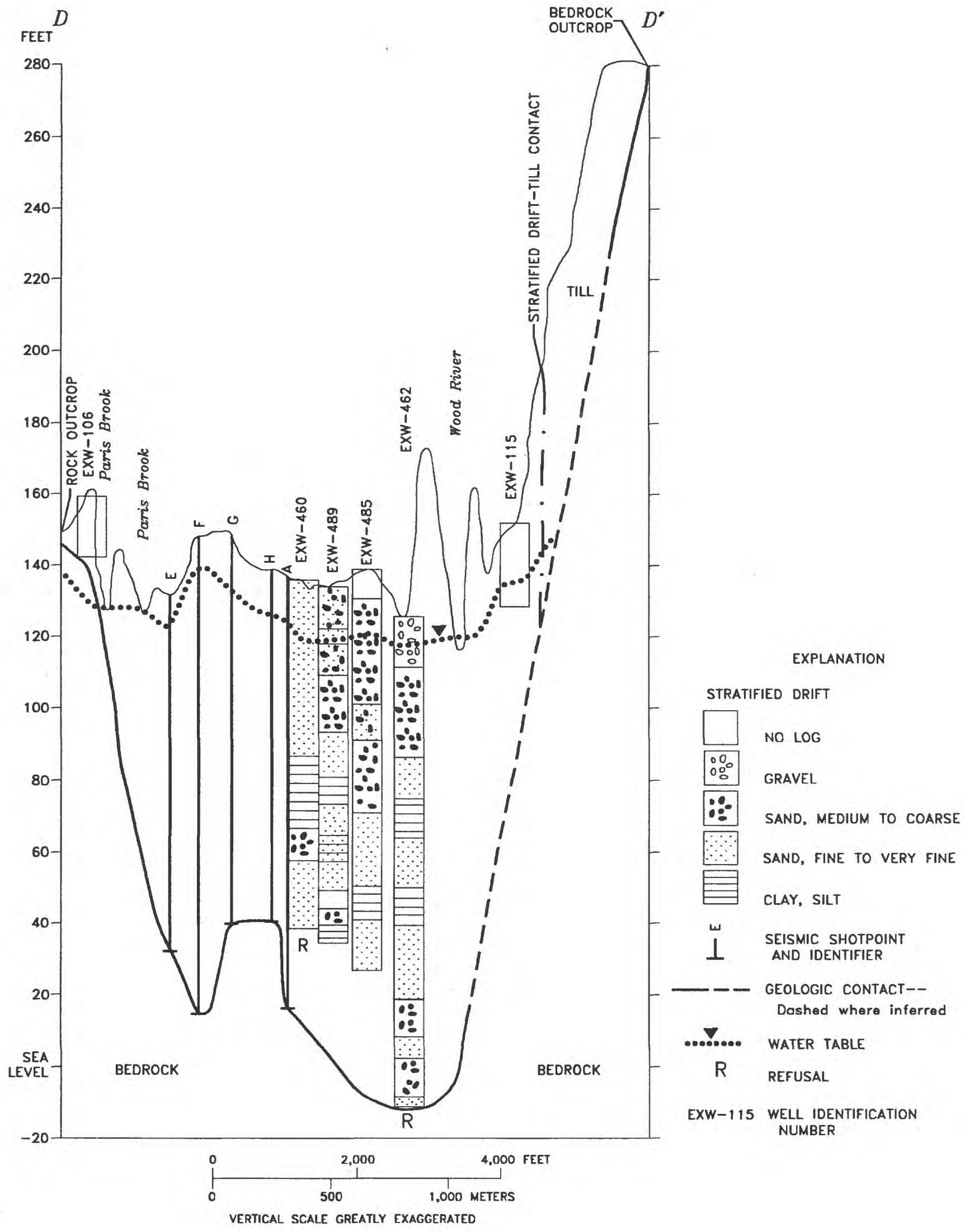

Figure 11.--Generalized geologic section D-D' north of Deep Pond (section trace shown in figure 2). 


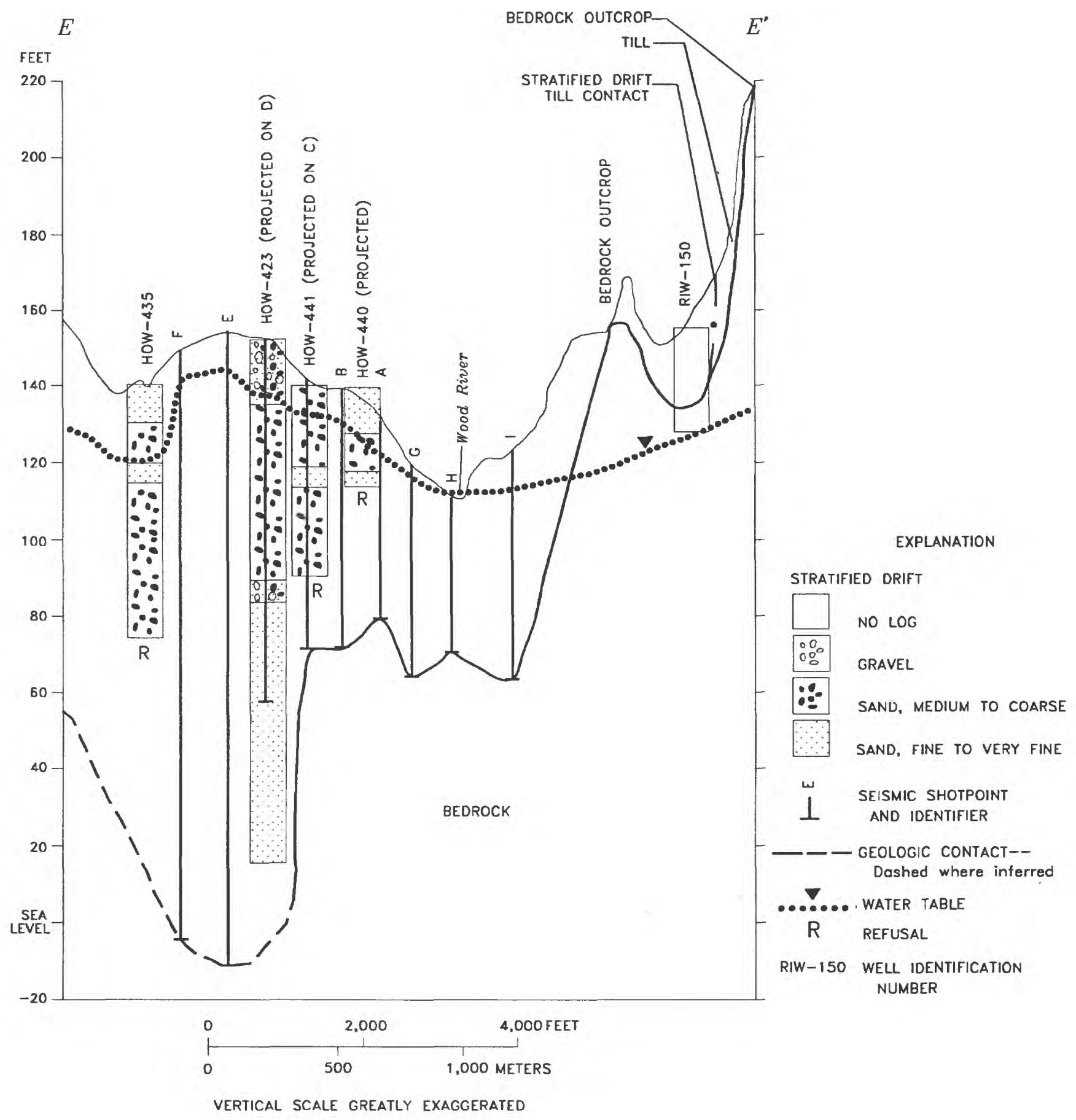

Figure 12.--Generalized geologic section E-E' north of Barberville (section trace shown in figure 2). 


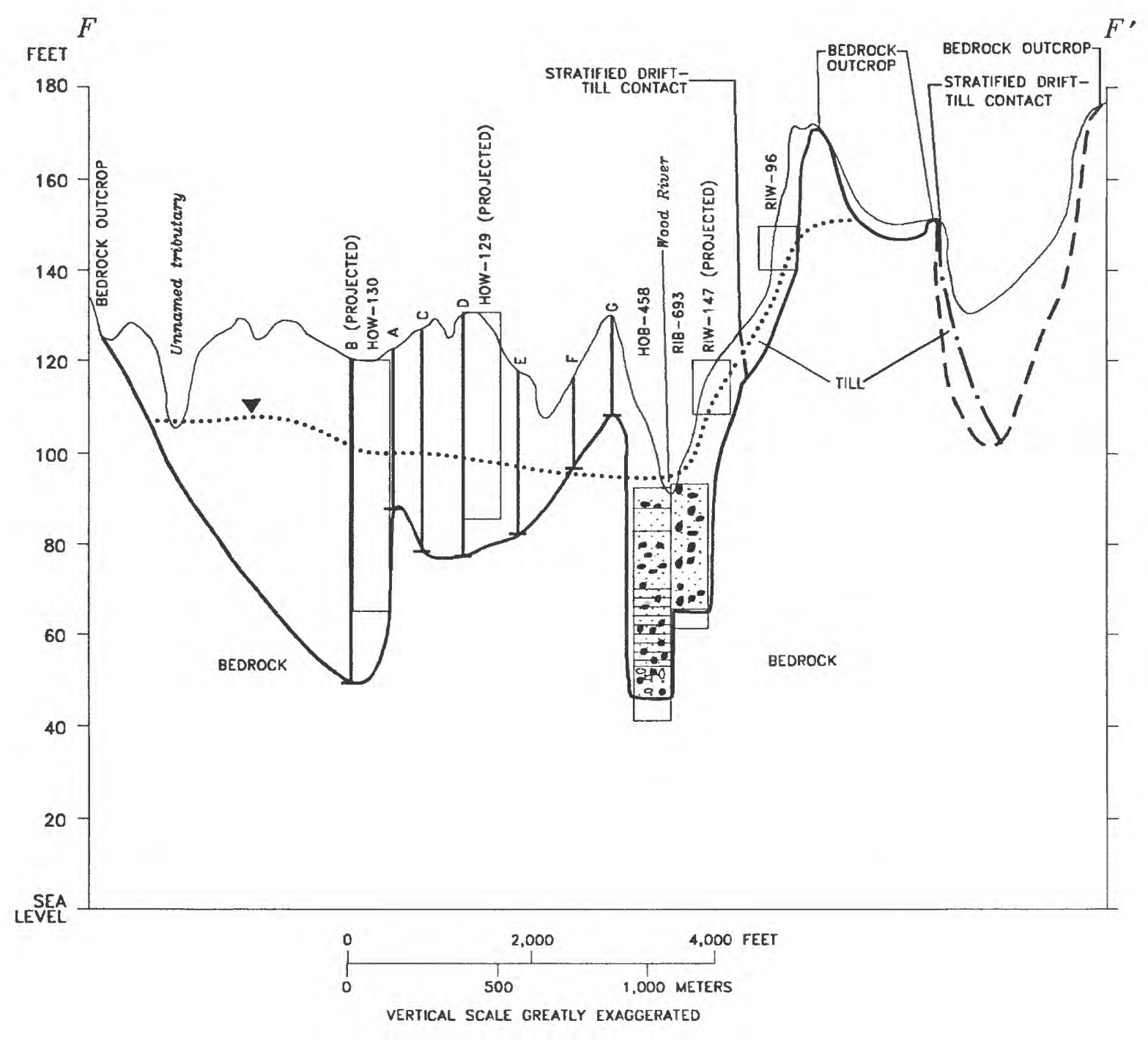

EXPLANATION

STRATIFIED DRIFT

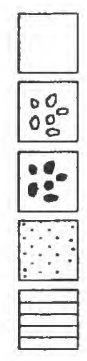

NO LOG

GRAVEL
SAND, MEDIUM TO COARSE

SAND, FINE TO VERY FINE

CLAY, SILT

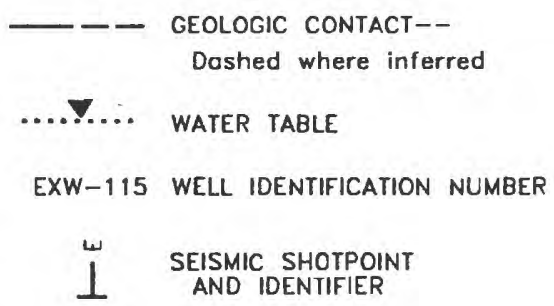

1 SEISMIC SHOTPOINT

Figure 13.--Generalized geologic section F-F' along Skunk Hill Road (section trace shown in figure 2). 
1986, and detailed lithologic logs of 300 wells and test holes, were analyzed to determine hydraulic properties of the aquifer. Transmissivity and storage coefficient describe the capacity of an aquifer to transmit, store, and yield water. The storage coefficient in a unconfined (water-table) aquifer is virtually equal to the specific yield (Lohman and others, 1972, p. 13). In water-table aquifers, the storage coefficient or specific yield generally ranges from about 0.05 to 0.30 (Ferris and others, 1962, p. 78).

The stratified-drift aquifer is heterogeneous and anisotropic. It is heterogeneous because of the complex lithology and interbedding shown in figures 8 through 13. The stratified-drift aquifer is anisotropic because the vertical and horizontal hydraulic conductivities differ. The anisotropy is due to (1) the interbedding of coarse and fine materials and (2) the horizontal orientation of the plate-shaped fine grains. These factors cause the hydraulic conductivity of the aquifer to be lower in the vertical direction. The stream-aquifer interaction plays a critical role in the geohydrologic system. The smaller vertical hydraulic conductivity of either the streambed or the aquifer affects the rate at which water moves from the stream into the aquifer and toward the well screen as induced infiltration during pumping.

The hydraulic properties of selected areas of the stratified drift were determined by the USGS and RIWRB by testing areas of the aquifer thought to be the most conductive to ground-water development. In each of the tests, 8 -in. wells were pumped at a constant rate ranging from 285 to $713 \mathrm{gal} / \mathrm{min}$ for 45 to 50 hours. Depth to the water table (static water level) ranged from 3.8 to $12.6 \mathrm{ft}$ below land surface before the aquifer tests. Pumped wells ranged in depth from 63 to $103 \mathrm{ft}$, and 15 to $25 \mathrm{ft}$ of screen was exposed near the bottom of each well.

The hydraulic properties of the stratified-drift aquifer were determined from analyses of unadjusted drawdown and recovery data from aquifer tests by one or more of the following methods: (1) Stallman's $(1963,1965)$ method for vertical movement in an unconfined, anisotropic aquifer; and (2) Cooper and Jacob's (1946) method for graphical solution to the modified nonleaky confined formula. Method 1 is described in Lohman (1979, p. 34-38), and method 2 is described in Walton (1962, p. 9). Assumptions inherent in each analytical method used to analyze aquifer-test data are summarized in table 3 . Conditions treated in the formulation of equations cited in references above are indicated by an $\mathrm{x}$ in the assumption column of table 3 .

Because the well screen is open to only part of the aquifer, data must be adjusted to correct for ad- ditional drawdown or recovery caused by the partial penetration of the well. In method 1, partial penetration is accounted for by choosing the proper curve for the solution. The curve depends on the amount of aquifer penetrated by the pumped well and the depth at which each observation well is open to the aquifer.

The transmissivity of the stratified-drift aquifer determined from these tests ranges from 7,600 to $49,200 \mathrm{ft}^{2} / \mathrm{d}$ and averages $25,100 \mathrm{ft}^{2} / \mathrm{d}$ (table 4 ). Horizontal hydraulic conductivity ranges from 120 to $965 \mathrm{ft} / \mathrm{d}$ and averages $395 \mathrm{ft} / \mathrm{d}$; vertical hydraulic conductivity ranges from 2 to $80 \mathrm{ft} / \mathrm{d}$ and averages $16 \mathrm{ft} / \mathrm{d}$ (table 4). The ratio of vertical to horizontal hydraulic conductivity of the stratified-drift aquifer ranges from 1:12 to 1:90 and averages 1:35.

Estimates of transmissivity were also made from lithologic logs as an additional means of checking hydraulic properties obtained by analysis of aquifertest data. The method used to estimate transmissivities from lithologic logs was also used in the Chipuxet River basin in southern Rhode Island, as explained in Dickerman (1984, p. 7-9). Well-construction and aquifer-test data, transmissivity estimates, methods of data analysis, and results of analyses are summarized in table 4.

The highest transmissivity in the upper Wood River valley was determined from an aquifer test at test well RIW (Richmond well) 712. Transmissivity at this site, computed by means of different analytical methods, ranges from 33,400 to $49,200 \mathrm{ft}^{2} / \mathrm{d}$ and averages $42,200 \mathrm{ft}^{2} / \mathrm{d}$. Estimated horizontal hydraulic conductivity of the aquifer at this site ranges from 605 to $965 \mathrm{ft} / \mathrm{d}$ and averages $815 \mathrm{ft} / \mathrm{d}$. Vertical hydraulic conductivity computed by using the Stallman method ranges from 10 to $47 \mathrm{ft} / \mathrm{d}$ and averages $28 \mathrm{ft} / \mathrm{d}$.

The lowest transmissivity in the upper Wood River valley was determined from an aquifer test at test well EXW 510, where transmissivity ranges from 7,600 to $38,800 \mathrm{ft}^{2} / \mathrm{d}$ and averages $16,300 \mathrm{ft}^{2} / \mathrm{d}$. Estimated horizontal hydraulic conductivity ranges from 140 to $540 \mathrm{ft} / \mathrm{d}$ and averages $265 \mathrm{ft} / \mathrm{d}$. Computed vertical hydraulic conductivity ranges from 9 to 28 $\mathrm{ft} / \mathrm{d}$ and averages $16 \mathrm{ft} / \mathrm{d}$.

The transmissivity map shown in figure 15 is the computer-generated product of the saturated thickness map (fig. 14) and hydraulic conductivities calculated from aquifer-test data or estimated from well lithology. The computer-generated transmissivity map was checked at the 11 aquifer-test sites to verify that the map was an accurate representation of the stratified-drift aquifer. Computer-generated transmissivity contours and transmissivities determined by using analytical methods are shown in figure 15. 


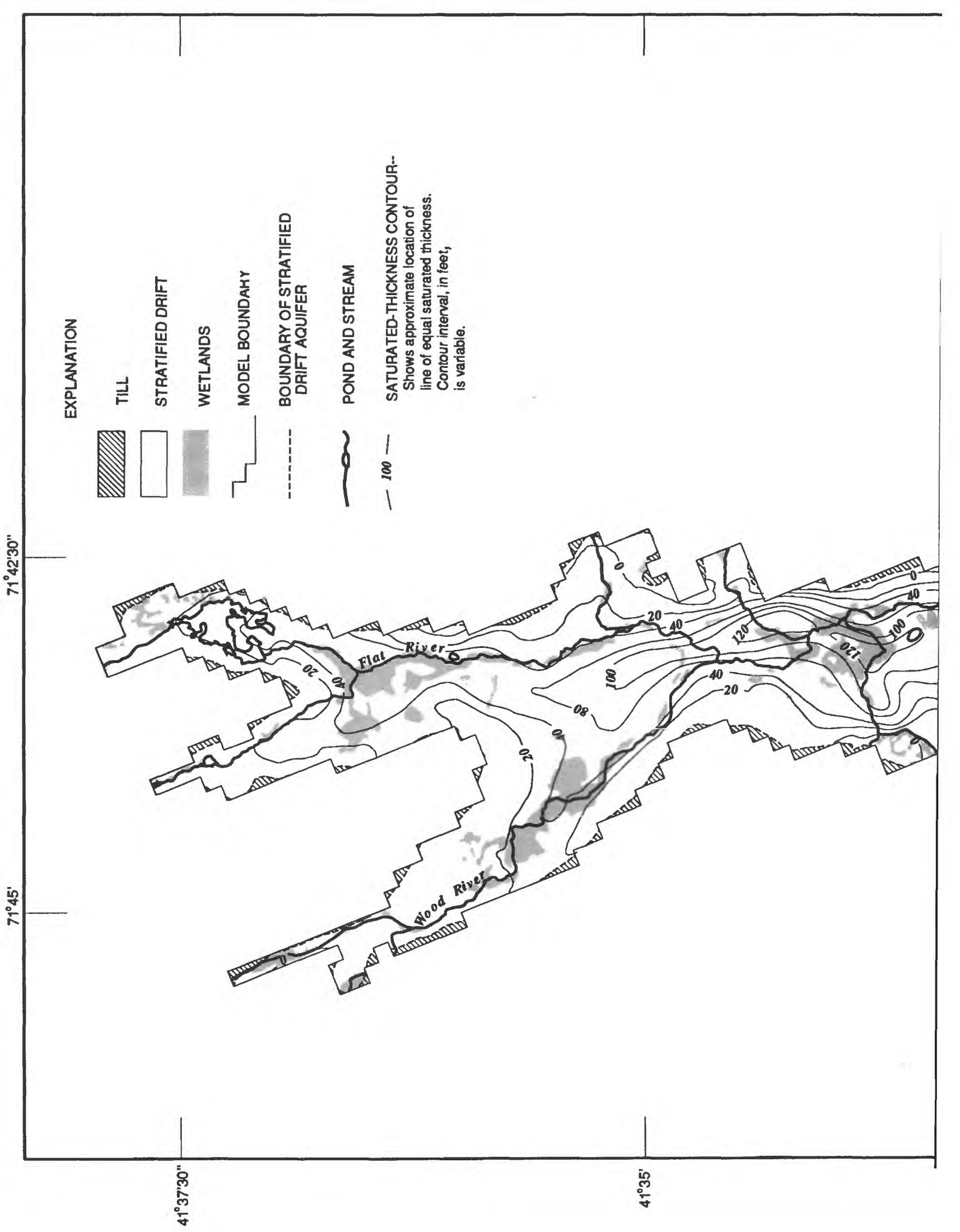




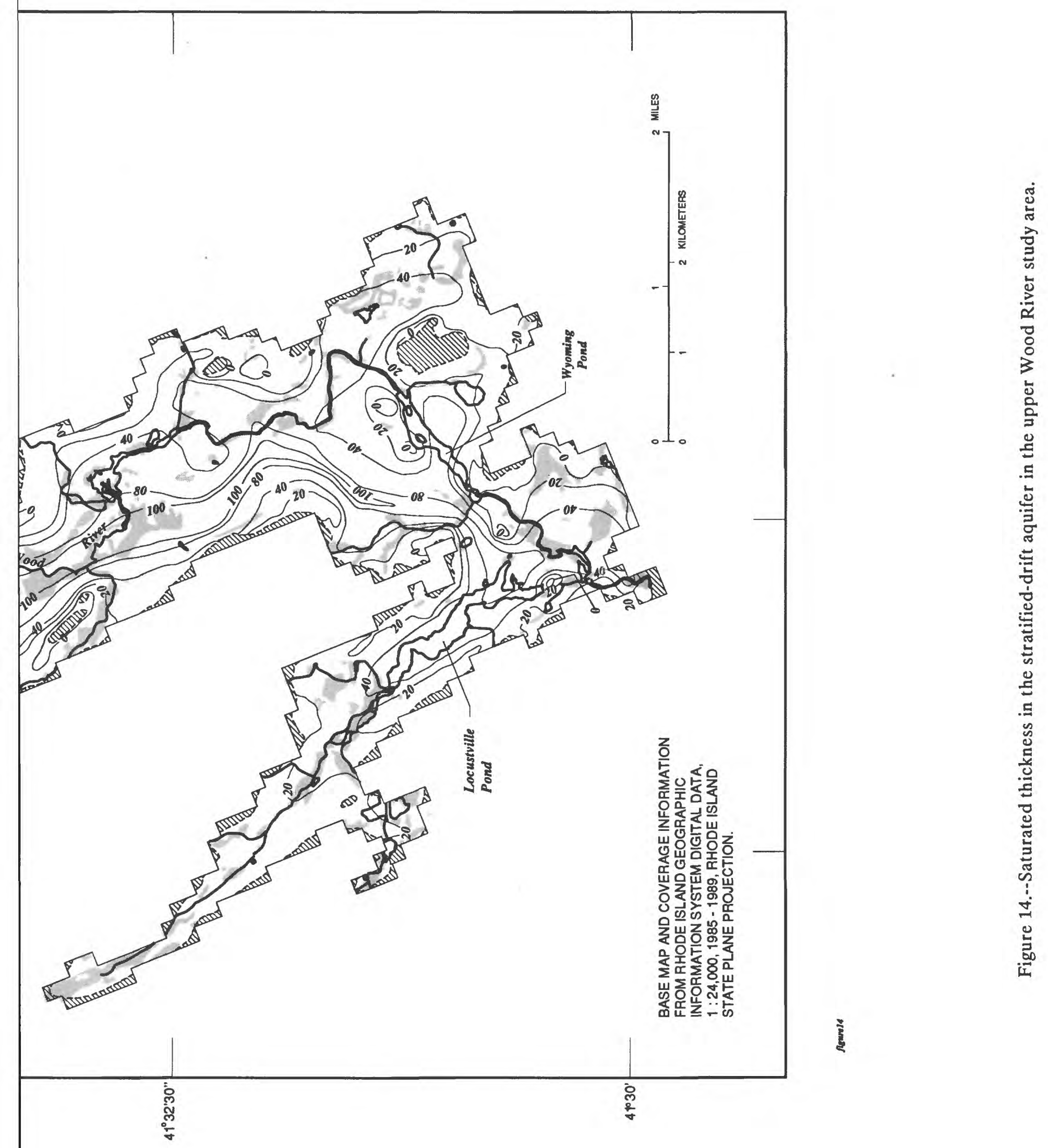


Table 3.--Assumptions used in analysis of aquifer-test data

$[x$, condition treated in formulation of equation cited in given reference; --, condition not treated in formulation of equation cited in given reference; adapted from Stallman, 1971]

\begin{tabular}{|c|c|c|c|}
\hline \multirow{2}{*}{\multicolumn{2}{|c|}{ Assumption }} & \multicolumn{2}{|c|}{ Analytical method } \\
\hline & & $\begin{array}{c}\text { Stallman } \\
(1963, \\
1965)\end{array}$ & $\begin{array}{c}\text { Cooper } \\
\text { and Jacob } \\
(1946)\end{array}$ \\
\hline \multirow[t]{5}{*}{ A. } & Pumped-well characteristics: & & \\
\hline & Full penetration & $\mathbf{x}$ & $\mathbf{x}$ \\
\hline & Partial penetration & $\mathbf{x}$ & -- \\
\hline & Diameter infinitesimal & -- & $\mathbf{x}$ \\
\hline & Diameter finite & $\mathbf{x}$ & - \\
\hline \multirow[t]{9}{*}{ B. } & Conductivity and flow conditions: & & \\
\hline & Homogeneous, isotropic & $\mathrm{x}$ & $\mathrm{x}$ \\
\hline & Homogeneous, anisotropic & $\mathrm{x}$ & -- \\
\hline & Areally infinite & $\mathbf{x}$ & $\mathbf{x}$ \\
\hline & Dewatering negligible & $\mathrm{x}$ & $\mathbf{x}$ \\
\hline & Flow radial & -- & $\mathbf{x}$ \\
\hline & Flow radial and vertical & $\mathbf{x}$ & -- \\
\hline & Nonsteady flow & $\mathrm{x}$ & $\mathrm{x}$ \\
\hline & Horizontal flow in aquifer & $\mathbf{x}$ & $\mathbf{x}$ \\
\hline \multirow[t]{5}{*}{ C. } & Storage relation: & & \\
\hline & Water released from storage & & \\
\hline & instantaneously & $\mathrm{x}$ & $\mathbf{x}$ \\
\hline & Confined (artesian) & -- & $\mathrm{x}$ \\
\hline & Unconfined (water table) & $\mathrm{x}$ & -- \\
\hline
\end{tabular}

Estimates of horizontal and vertical hydraulic conductivity determined from the results of these short-term aquifer tests are adequate, but longerterm tests are required for accurate estimates of storage coefficients. For this reason, results of laboratory analyses of specific yield from a previous study in a similar hydrogeologic setting were used (Allen and others, 1963). The storage coefficient was assumed to be 0.20 .

In summary, site averages for hydraulic conductivity and transmissivity shown in table 4 are probably higher than those for much of the stratified drift in the upper Wood River study area. This is because aquifer-test sites were in areas expected to yield large quantities of water on the basis of extensive exploratory test drilling. Therefore, the test results and reported well yields in the report indicate what may be expected from properly constructed wells that penetrate the stratified drift in the more productive parts of the upper Wood River ground-water reservoir. The sites most favorable for development of high-capacity wells (1 Mgal/d or more), on the basis of aquifer testing completed to date, are primarily within $200 \mathrm{ft}$ of the Flat River or the Wood River.

\section{Sources of Recharge}

"Water available for recharge is often a more useful concept or quantity to estimate than is recharge itself" (Lyford and Cohen, 1988). For purposes of this report, water available for ground-water 
recharge was assumed to be equal to long-term average annual runoff. Surface runoff is probably negligible in most areas underlain by sand and gravel (Pluhowski and Kantrowitz, 1964).

Annual runoff calculated from data from the long-term continuous-record streamflow-gaging station on the Wood River at Hope Valley for calendar years 1942 through 1989 indicate that long-term average annual runoff is about $29 \mathrm{in}$. Therefore, a value of $29 \mathrm{in} / \mathrm{yr}$ was used for recharge in the groundwater model of the aquifer. It was assumed that ground-water recharge would be rejected by the aquifer in areas where the water table was at land surface (that is, streams, lakes, ponds, and swamps). Therefore, recharge was not applied to these areas. An annual recharge rate of $29 \mathrm{in}$. to the stratified drift is equivalent to about 21 in. when evenly distributed. Water potentially available for recharge in the upper Wood River aquifer is derived principally from three sources: (1) infiltration of precipitation that falls directly on the stratified drift, (2) lateral inflow from till/bedrock uplands, and (3) leakage from streams.

\section{Precipitation on the stratified drift}

Under natural conditions, the primary source of recharge to the aquifer is precipitation directly on the stratified drift, where most of the rain and snowmelt infiltrates the soil. For the period 1942 through 1989, precipitation at the National Weather Bureau station in Kingston, R.I., averaged $47.6 \mathrm{in}$. Of the $47.6 \mathrm{in}$. of precipitation, $29.4 \mathrm{in}$. discharges to the stream as runoff, and $18.2 \mathrm{in}$. is returned to the atmosphere by evaporation and transpiration.

\section{Lateral inflow from the till/bedrock uplands}

The upper Wood River valley is bordered by till/bedrock uplands of low hydraulic conductivity. These low-permeability materials restrict the amount of rain and snowmelt that can infiltrate the soil. Water that falls as precipitation on the uplands recharges the stratified-drift aquifer in three ways. Precipitation infiltrates the soil in the till/bedrock uplands and becomes ground water that moves downgradient laterally through the till and bedrock toward the valley floor where it recharges the stratified drift. Precipitation that does not infiltrate the soil either flows overland and downslope in areas not drained by upland streams until it reaches the valley floor, where it infiltrates the stratified drift and becomes recharge; or becomes streamflow in areas drained by upland streams, where it becomes available for induced recharge.

\section{$\underline{\text { Leakage from streams }}$}

Under natural conditions, the water table normally slopes toward the stream and ground water discharges from the stratified drift into the stream. Most streams in the study area receive ground-water runoff and are therefore gaining streams; however, some streams may lose water to the aquifer under natural conditions because the water level in the aquifer is below the stream level. In the upper Wood River study area, Baker Brook is a naturally losing stream. Small streams draining till/bedrock uplands also may be naturally losing streams as they flow onto the more permeable valley-floor sediments.

If wells near the stream are pumped, the watertable gradient to the stream decreases and groundwater runoff to a gaining stream is reduced. If pumping is of sufficient volume and duration, the hydraulic gradient may be reversed, causing water from the stream to move by induced infiltration through the streambed into the stratified-drift aquifer.

The amount of water induced to flow from streams to wells is governed by (1) the vertical hydraulic conductivity of the streambed and underlying aquifer, (2) the streambed thickness, (3) the area of streambed through which infiltration occurs, (4) the viscosity of the water, (5) the average head difference between the stream level and aquifer within the streambed area of infiltration, and (6) the quantity of water in the stream.

The streambeds of the Flat and Wood Rivers are generally composed of loosely packed sand and gravel, except in ponded and swampy areas. These loosely packed streambeds are assumed to have a vertical hydraulic conductivity that is higher than that of the underlying stratified-drift aquifer, which typically contains layers of fine silt or silty sand. On the basis of this assumption, the effective streambed hydraulic conductivity was assumed to be the average vertical hydraulic conductivity of the underlying aquifer.

The vertical hydraulic conductivity of the stratified-drift aquifer was determined from data collected during seven of the controlled aquifer tests: one at a site along the Flat River and six at sites along the Wood River. Values of vertical hydraulic conductivity at these sites ranged from 2 to $80 \mathrm{ft} / \mathrm{d}$, with a median of $7 \mathrm{ft} / \mathrm{d}$.

The quantity of streamflow to be maintained during low-flow periods limits the amount of water 
Table 4.--Summary of hydraulic properties determined from aquifer tests of the stratified-drift aquifer

[in., inches; ft, feet; hrs, hours; gal/min, gallons per minute; (gal/min)/ft, gallons per minute per foot; $\mathrm{ft}^{2} / \mathrm{d}$, square feet per day; ft/d, feet per day; --, no data available; Comp, composite plot produced from multiple wells]

Well-construction and aquifer-test data for pumped well

\begin{tabular}{|c|c|c|c|c|c|c|c|c|c|}
\hline $\begin{array}{l}\text { Pumped- } \\
\text { well } \\
\text { number } 1\end{array}$ & $\begin{array}{l}\text { Nominal } \\
\text { inside } \\
\text { diameter } \\
\text { (in.) }\end{array}$ & $\begin{array}{l}\text { Screened } \\
\text { interval }^{2,3} \\
\text { (ft) }\end{array}$ & $\begin{array}{l}\text { Static } \\
\text { water } \\
\text { level }^{3} \\
\text { (ft) }\end{array}$ & $\begin{array}{c}\text { Date of } \\
\text { aquifer } \\
\text { test }\end{array}$ & $\begin{array}{c}\text { Length } \\
\text { of } \\
\text { test } \\
\text { (hrs) }\end{array}$ & $\begin{array}{c}\text { Pumping } \\
\text { rate } \\
\text { (gal } / \mathrm{min} \text { ) }\end{array}$ & $\begin{array}{l}\text { Draw- } \\
\text { down } \\
\text { (ft) }\end{array}$ & $\begin{array}{c}\text { Specific } \\
\text { capacity } \\
\text { ((gal/min) } \\
\text { /ft) }\end{array}$ & $\begin{array}{c}\text { Transmissivity } \\
\text { estimated from } \\
\text { lithologic log } \\
\left(\mathrm{ft}^{2} / \mathrm{d}\right)\end{array}$ \\
\hline \multicolumn{10}{|c|}{ Town of Exeter } \\
\hline 481 & 8 & $85 \cdot 100$ & 5.25 & $12-02-80$ & 48.2 & 550 & 45.75 & 12.0 & 12,700 \\
\hline
\end{tabular}

\begin{tabular}{llllllllll}
\hline 510 & 8 & $59-74.6$ & 12.61 & $04-19-82$ & 48 & 300 & 29.43 & 10.2 & 6,650
\end{tabular}

$\begin{array}{llllllllll}515 & 8 & 77.5-93.1 & 4.83 & 05-10-82 & 48 & 512 & 55.66 & 9.2 & 15,700\end{array}$

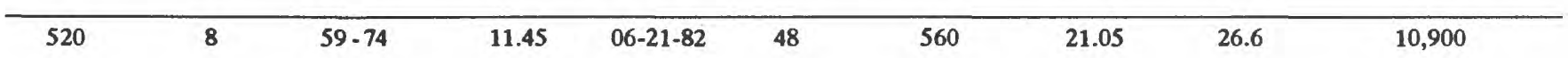

\begin{tabular}{|c|c|c|c|c|c|c|c|c|c|}
\hline 525 & 8 & $48-63$ & 9.47 & $06-28-82$ & 48 & 575 & 14.88 & 38.6 & 11,300 \\
\hline 547 & 8 & $88 \cdot 103$ & 4.54 & $07-19-83$ & 48 & 660 & 52.99 & 12.5 & 14,400 \\
\hline
\end{tabular}

See footnotes at end of table. 
Table 4.--Summary of hydraulic properties determined from aquifer tests of the stratified-drift aquifer--Continued

\begin{tabular}{|c|c|c|c|c|c|c|}
\hline \multirow[b]{3}{*}{$\begin{array}{l}\text { Meth- } \\
\text { od }^{4}\end{array}$} & \multirow{3}{*}{$\begin{array}{l}\text { Obser- } \\
\text { vation- } \\
\text { well } \\
\text { number }{ }^{1}\end{array}$} & \multirow{3}{*}{$\begin{array}{c}\text { Distance } \\
\text { from pumped } \\
\text { well } \\
\text { (ft) }\end{array}$} & \multicolumn{3}{|c|}{$\begin{array}{l}\text { Hydraulic properties determined } \\
\text { by using analytical methods }\end{array}$} & \multirow[b]{3}{*}{$\begin{array}{c}\text { Pumped } \\
\text { well } \\
\text { number }\end{array}$} \\
\hline & & & \multirow{2}{*}{$\begin{array}{c}\text { Trans- } \\
\text { missiv- } \\
\text { ity } \\
\left(\mathrm{ft}^{2} / \mathrm{d}\right)\end{array}$} & \multicolumn{2}{|c|}{ Hydraulic conductivity } & \\
\hline & & & & $\begin{array}{c}\text { Horizontal } \\
\text { (ft/d) }\end{array}$ & $\begin{array}{c}\text { Vertical } \\
\text { (ft/d) }\end{array}$ & \\
\hline \multicolumn{7}{|c|}{ Town of Exeter } \\
\hline a & 484 & 77 & 18,200 & 175 & 8 & 481 \\
\hline a & 488 & 137 & 12,500 & 120 & 7 & \\
\hline a & 486 & 202 & 21,200 & 200 & 6 & \\
\hline a & 489 & 299 & 26,500 & 250 & 15 & \\
\hline $\mathbf{a}$ & 485 & 486 & 21,600 & 205 & -- & \\
\hline a & Comp $^{6}$ & Comp ${ }^{6}$ & 22,800 & 215 & -- & \\
\hline \multirow[t]{2}{*}{ b } & Comp $^{6}$ & Comp $^{6}$ & 12,500 & 120 & $\ldots$ & \\
\hline & & Site ave rage & 19,300 & 185 & 9 & \\
\hline a & 528 & 100 & 11,000 & 210 & 28 & 510 \\
\hline $\mathbf{a}$ & 530 & 200 & 13,800 & 260 & 9 & \\
\hline a & 531 & 300 & 7,600 & 140 & 10 & \\
\hline a & 507 & 750 & 38,800 & 540 & -- & \\
\hline \multirow[t]{2}{*}{ b } & Comp $^{6}$ & Comp $^{6}$ & 10,200 & 170 & -- & \\
\hline & & Site average & 16,300 & 265 & 16 & \\
\hline a & 508 & 98 & 22,400 & 230 & 5 & 515 \\
\hline a & 526 & 205 & 28,600 & 365 & 6 & \\
\hline a & 507 & 424 & 35,200 & 490 & 7 & \\
\hline a & 527 & 480 & 26,000 & 350 & 4 & \\
\hline a & Comp $^{6}$ & Comp $^{6}$ & 28,200 & 335 & - & \\
\hline \multirow[t]{2}{*}{ b } & Comp $^{6}, 509$ & Comp $^{6}, 584$ & 14,200 & 170 & $\therefore$ & \\
\hline & & Site average & 25,800 & 325 & 6 & \\
\hline a & 518 & 104 & 30,800 & 540 & 18 & 520 \\
\hline a & 521 & 210 & 34,200 & 600 & 5 & \\
\hline a & 522 & 504 & 36,000 & 680 & 4 & \\
\hline a & 517 & 757 & 30,800 & 630 & 6 & \\
\hline a & 516 & 1,058 & 28,400 & 565 & 3 & \\
\hline a & 512 & 1,258 & 24,500 & 415 & 2 & \\
\hline $\mathbf{a}$ & Comp ${ }^{6}$ & Comp ${ }^{6}$ & 28,400 & 500 & -- & \\
\hline \multirow[t]{2}{*}{ b } & Comp ${ }^{6}$ & Comp ${ }^{6}$ & $\underline{24,700}$ & 435 & $\ldots$ & \\
\hline & & Site average & 29,700 & 545 & 6 & \\
\hline a & 513 & 100 & 34,600 & 720 & 80 & 525 \\
\hline $\mathbf{a}$ & 516 & 202 & 37,500 & 750 & 22 & \\
\hline a & Comp $^{6}, 517$ & Comp $^{6}, 504$ & 31,600 & 565 & -- & \\
\hline \multirow[t]{2}{*}{ b } & Comp $^{6}, 511,517$ & Comp $^{6}, 1,262,504$ & 26,000 & 465 & -- & \\
\hline & & Site average & 32,400 & 625 & $\$ 1$ & \\
\hline $\mathbf{a}$ & 543 & 102 & 22,700 & 225 & 8 & 547 \\
\hline a & 545 & 298 & 25,400 & 320 & 11 & \\
\hline a & 546 & 422 & 23,600 & 275 &.- & \\
\hline a & 535 & 489 & 36,300 & 490 & 5 & \\
\hline a & Comp ${ }^{6}$ & Comp $^{6}$ & 26,400 & 265 & -. & \\
\hline \multirow[t]{2}{*}{ b } & Comp $^{6}, 504,{ }^{7} 543$ & Comp $^{6}, 560$ & $\underline{20,200}$ & 200 &.- & \\
\hline & & Site average & 25,800 & 295 & 8 & \\
\hline
\end{tabular}

See footnotes at end of table. 
Table 4.--Summary of hydraulic properties determined from aquifer tests of the stratified-drift aquifer--Continued

\begin{tabular}{|c|c|c|c|c|c|c|c|c|c|}
\hline \multirow[b]{2}{*}{$\begin{array}{l}\text { Pumped- } \\
\text { well } \\
\text { number } 1\end{array}$} & \multicolumn{8}{|c|}{ Well-construction and aquifer-test data for pumped well } & \multirow[b]{2}{*}{$\begin{array}{c}\text { Transmissivity } \\
\text { estimated from } \\
\text { lithologic log } \\
\left(\mathrm{ft}^{2} / \mathrm{d}\right)\end{array}$} \\
\hline & $\begin{array}{c}\text { Nominal } \\
\text { inside } \\
\text { diameter } \\
\text { (in.) }\end{array}$ & $\begin{array}{l}\text { Screened } \\
\text { interval }^{2,3} \\
(\mathrm{ft})\end{array}$ & $\begin{array}{c}\text { Static } \\
\text { water } \\
\text { level }^{3} \\
(\mathrm{ft})\end{array}$ & $\begin{array}{c}\text { Date of } \\
\text { aquifer } \\
\text { test }\end{array}$ & $\begin{array}{c}\text { Length } \\
\text { of } \\
\text { test } \\
\text { (hrs) }\end{array}$ & $\begin{array}{c}\text { Pumping } \\
\text { rate } \\
\text { (gal } / \mathrm{min} \text { ) }\end{array}$ & $\begin{array}{c}\text { Draw- } \\
\text { down } \\
\text { (ft) }\end{array}$ & $\begin{array}{c}\text { Specific } \\
\text { capacity } \\
((\mathrm{gal} / \mathrm{min}) \\
/ \mathrm{ft})\end{array}$ & \\
\hline \multicolumn{10}{|c|}{ Town of Exeter--Continued } \\
\hline 552 & 8 & $70-85$ & 3.81 & $06-23-86$ & 48 & 680 & 18.12 & 37.5 & 11,400 \\
\hline \multicolumn{10}{|c|}{ Town of Hopkinton } \\
\hline 445 & 8 & $77-92$ & 9.10 & $03-02-81$ & 45.1 & 538 & 35.00 & 15.4 & 4,900 \\
\hline 477 & 8 & $56-72$ & 7.75 & $08-23-83$ & 50 & 713 & 25.75 & 27.7 & 10,600 \\
\hline \multicolumn{10}{|c|}{ Town of Richmond } \\
\hline 696 & 8 & $48-63$ & 8.15 & $01-12-81$ & 48 & 285 & 15.08 & 18.9 & 9,850 \\
\hline & & $82-87$ & & & & & & & \\
\hline 712 & 8 & $52-67$ & 3.83 & $02-09-81$ & 45 & 491 & 26.86 & 18.3 & 13,200 \\
\hline
\end{tabular}

See footnotes at end of table. 
Table 4.--Summary of hydraulic properties determined from aquifer tests of the stratified-drift aquifer--Continued

\begin{tabular}{|c|c|c|c|c|c|c|}
\hline \multirow[b]{3}{*}{$\begin{array}{l}\text { Meth- } \\
\text { od }^{4}\end{array}$} & \multirow{3}{*}{$\begin{array}{l}\text { Obser- } \\
\text { vation- } \\
\text { well } \\
\text { number } 1\end{array}$} & \multirow{3}{*}{$\begin{array}{c}\text { Distance } \\
\text { from pumped } \\
\text { well } \\
\text { (ft) }\end{array}$} & \multicolumn{3}{|c|}{$\begin{array}{l}\text { Hydraulic properties determined } \\
\text { by using analytical methods }\end{array}$} & \multirow[b]{3}{*}{$\begin{array}{l}\text { Pumped- } \\
\text { well } \\
\text { number }\end{array}$} \\
\hline & & & \multirow{2}{*}{$\begin{array}{l}\text { Trans- } \\
\text { missiv- } \\
\text { ity } \\
\left(\mathrm{ft}^{2} / \mathrm{d}\right)\end{array}$} & \multicolumn{2}{|c|}{ Hydraulic conductivity } & \\
\hline & & & & $\begin{array}{l}\text { Horizontal } \\
(\mathrm{ft} / \mathrm{d})\end{array}$ & $\begin{array}{l}\text { Vertical } \\
\text { (ft/d) }\end{array}$ & \\
\hline \multicolumn{7}{|c|}{ Town of Exeter--Continued } \\
\hline a & 548 & 97 & 25,200 & 325 & 5 & 552 \\
\hline a & 550 & 278 & 23,400 & 320 & 27 & \\
\hline a & 551 & 469 & 14,500 & 215 & 2 & \\
\hline a & Comp $^{6}$ & Comp $^{6}$ & 24,700 & 295 & - & \\
\hline \multirow[t]{2}{*}{ b } & Comp $^{6}$ & Comp 6 & 15,500 & 190 & -- & \\
\hline & & Site ave rage & 20,700 & 270 & 11 & \\
\hline \multicolumn{7}{|c|}{ Town of Hopkinton } \\
\hline a & 450 & 74 & 35,200 & 525 & 35 & 445 \\
\hline a & 452 & 96 & 24,700 & 365 & 5 & \\
\hline a & 449 & 164 & 33,400 & 565 & 2 & \\
\hline a & 448 & 204 & 25,900 & 370 & 5 & \\
\hline a & 454 & 294 & 30,500 & 395 & 4 & \\
\hline a & 456 & 504 & 28,800 & 370 & 4 & \\
\hline a & Comp $^{6}$ & Comp $^{6}$ & 32,400 & 390 & -- & \\
\hline \multirow[t]{2}{*}{ b } & Comp $^{6}, 446$ & $\operatorname{Comp}^{6}, 2$ & 11,100 & 135 & $\ldots$ & \\
\hline & & Site ave rage & 27,800 & 390 & 9 & \\
\hline a & 476 & 98 & 19,400 & 365 & 51 & 477 \\
\hline a & 474 & 300 & 22,200 & 450 & 26 & \\
\hline a & 475 & 496 & 19,600 & 465 & 7 & \\
\hline a & Comp ${ }^{6}$ & Comp $^{6}$ & 21,400 & 330 & - & \\
\hline \multirow[t]{2}{*}{ b } & $\operatorname{Comp}^{6}, 461$ & $\operatorname{Comp}^{6}, 764$ & 13,900 & 215 & $\ldots$ & \\
\hline & & Site average & 19,300 & 365 & 28 & \\
\hline \multicolumn{7}{|c|}{ Town of Richmond } \\
\hline a & 703 & 81 & 22,600 & 275 & 7 & 696 \\
\hline a & 704 & 139 & 17,400 & 250 & 7 & \\
\hline $\mathbf{a}$ & 706 & 185 & 15,800 & 290 & 3 & \\
\hline a & 709 & 669 & 17,200 & 260 & 6 & \\
\hline a & Comp $^{6}$ & Comp $^{6}$ & 16,900 & 240 & -- & \\
\hline \multirow[t]{2}{*}{ b } & Comp $^{6}, 699,{ }^{7} 709$ & Comp $^{6}, 2$ & 15,400 & 220 & $\ldots$ & \\
\hline & & Site average & 17,600 & 255 & 6 & \\
\hline a & 717 & 76 & 44,600 & 875 & 42 & 712 \\
\hline a & 722 & 151 & 44,600 & 890 & 47 & \\
\hline a & 721 & 205 & 37,800 & 740 & 22 & \\
\hline a & 719 & 310 & 42,000 & 840 & 10 & \\
\hline a & 718 & 507 & 49,200 & 965 & 21 & \\
\hline a & Comp $^{6}$ & Comp $^{6}$ & 44,000 & 800 & - & \\
\hline \multirow[t]{2}{*}{ b } & Comp $^{6}$ & Comp $^{6}$ & 33,400 & 605 & -.. & \\
\hline & & Site ave rage & 42,200 & 815 & 28 & \\
\hline
\end{tabular}

${ }^{1}$ Well identification number based on the town in which the well is located. See figure 2 for location of pumped well.

2 Bottom of screened interval is well depth.

${ }^{3}$ Feet below land-surface datum.

${ }^{4}$ (a) Vertical movement (Stallman, 1963, 1965) described in Lohman (1979), p. 34-38; and (b) modified nonleaky confined (Cooper and Jacob, 1946) described in Walton (1962), p. 9.

5 Transmissivity divided by distance from static water level to bottom of screen in pumped well.

${ }^{6}$ All observation wells and distances listed for this test, except as noted, were used during multiple well analysis.

${ }^{7}$ Well not used during multiple well analysis. 


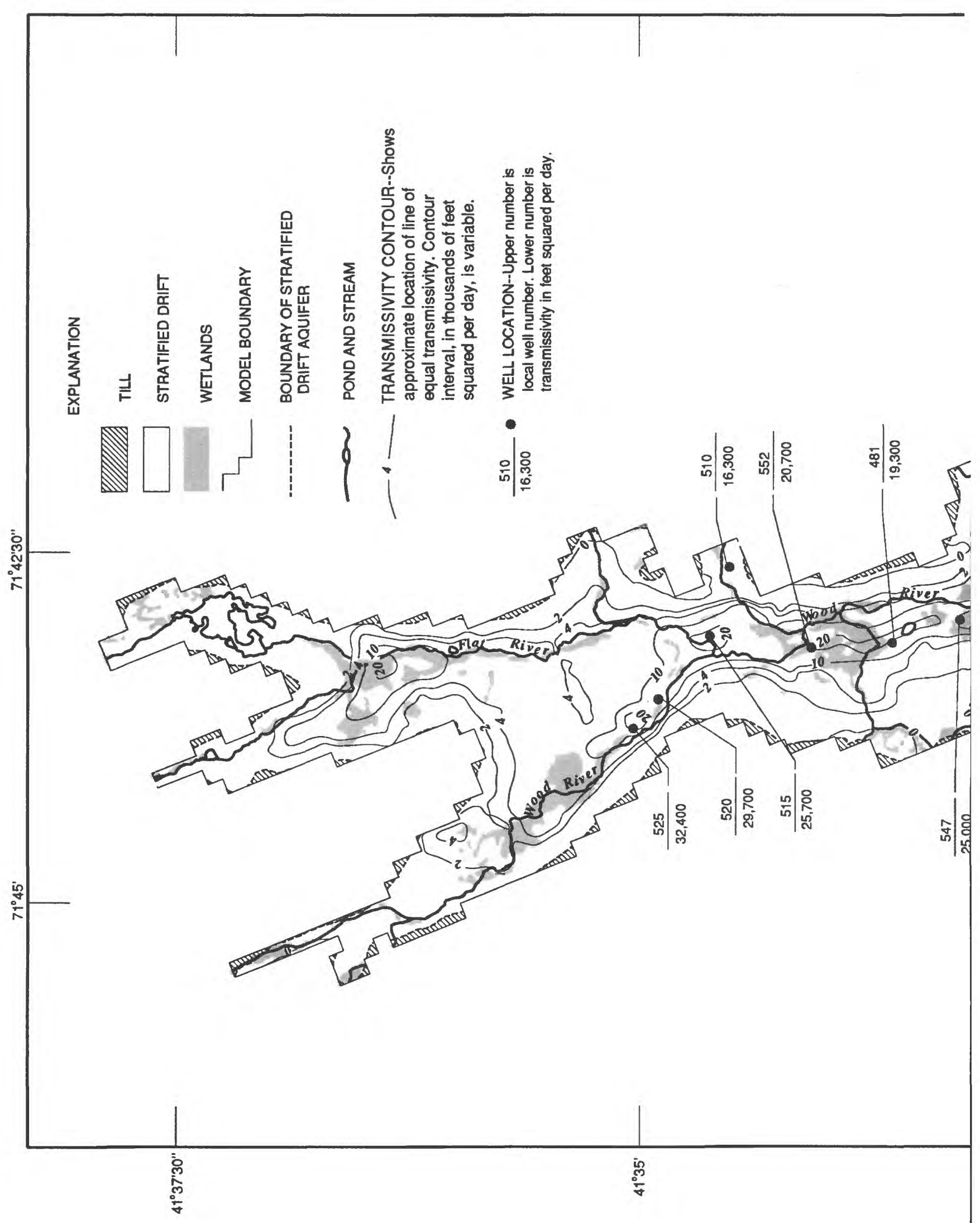




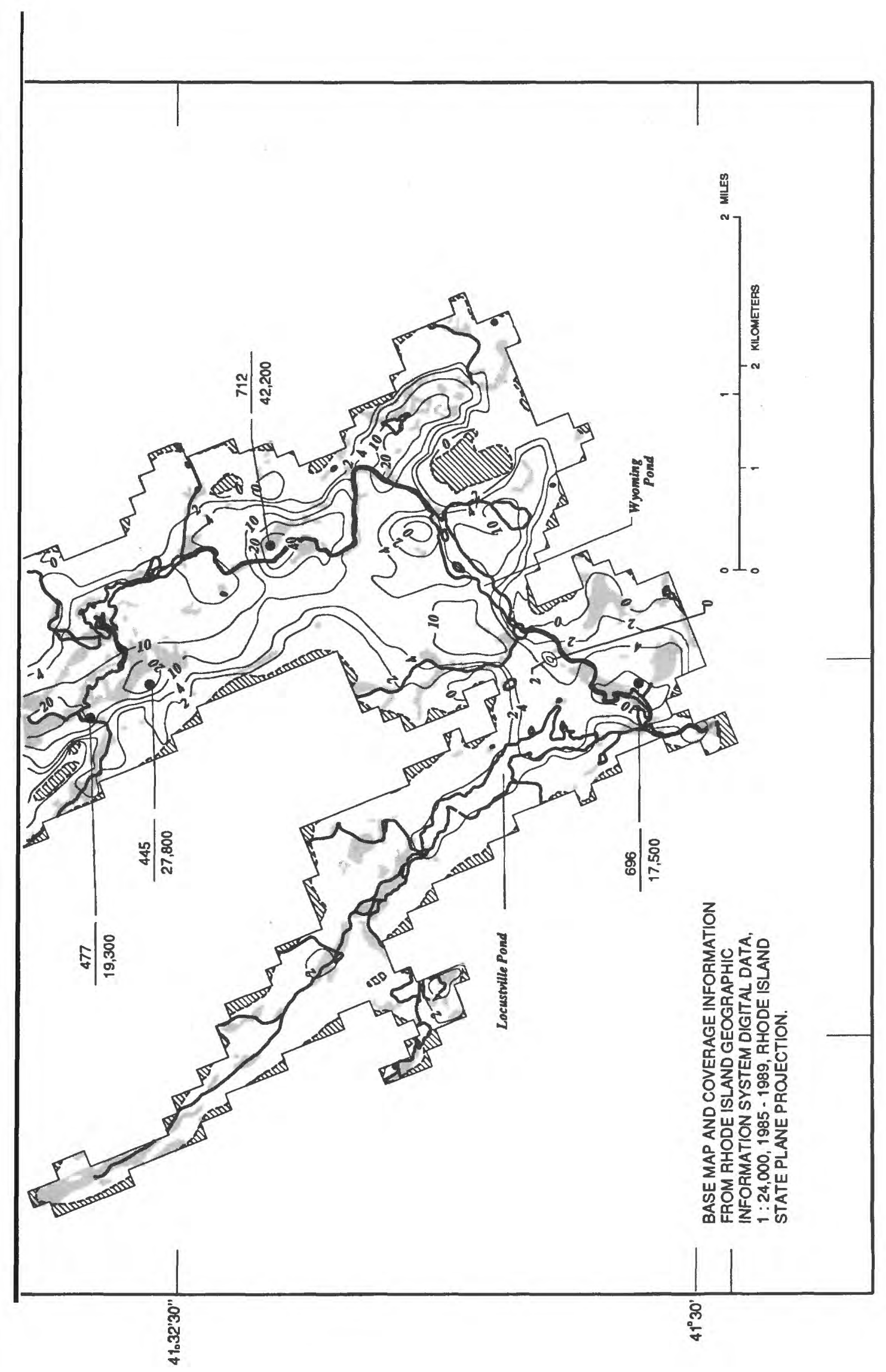

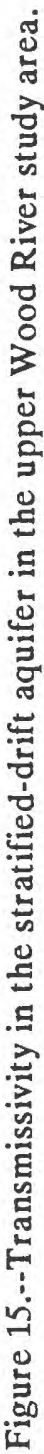


available for induced recharge to the stratified-drift aquifer. For this study, all streamflow above the 99percent flow duration $\left(20.2 \mathrm{ft}^{3} / \mathrm{s}\right)$ for the Wood River near Hope Valley was considered available for induced recharge to the aquifer.

\section{Bedrock and Till Aquifers}

Bedrock and till are capable of yielding usable quantities of water to wells and, therefore, they may constitute aquifers. In general, the crystalline rocks have a porosity of less than 1 percent. As a result, the yield of bedrock wells relates directly to the number of joints and fractures that the well intercepts. Water-bearing fractures in the crystalline bedrock decrease in size and frequency with depth and become sparse below $300 \mathrm{ft}$ (Allen and Kinnison, 1953, p. 27). Reported yields of wells in the bedrock aquifer range from 1.5 to $80 \mathrm{gal} / \mathrm{min}$ from depths of 50 to $465 \mathrm{ft}$ (Dickerman and others, 1989, table 1). The median yield of bedrock wells in the study area is $10 \mathrm{gal} / \mathrm{min}$, and the median well depth is $140 \mathrm{ft}$.

Although till is generally not considered a usable water-bearing material, it does constitute an aquifer capable of yielding small quantities of water for domestic and agricultural use. Generally, till does not yield more than $5 \mathrm{gal} / \mathrm{min}$ to large-diameter wells (Bierschenk and Hahn, 1959; LaSala and Hahn, 1960). Wells in till typically become dry during droughts and may become dry annually during late summer or early fall.

\section{WATER QUALITY}

Many factors, including natural processes and human activities, can affect water quality. A common measure of water quality is the quantity and type of chemical constituents dissolved in water. Among the natural factors that can affect the amounts of dissolved constituents in water are the type of consolidated and unconsolidated material with which the water comes in contact, the duration of the contact, and the quality of precipitation (Biesecker and Leifeste, 1975, p. 3). In the upper Wood River study area, the soil, bedrock, and glacial deposits consist primarily of silicate minerals that are relatively insoluable in water. As a result, ground water unaffected by human activities contains low concentrations (less than $100 \mathrm{mg} / \mathrm{L}$ ) of dissolved constituents. Ground water contains higher concentrations of dissolved solids than surface water because the water is in contact with the consolidated and unconsolidated material for a longer time.

Precipitation also contributes chemical constituents to water. Although the dissolved-solids content of precipitation can be variable, it is thought to be very low on the basis of data from analyses of precipitation on Block Island (Emily Burns, unpublished data on file at U.S. Geological Survey office in Providence, Rhode Island). Between August 1988 and October 1989, 13 precipitation samples collected at the atmospheric-deposition site on Block Island had dissolved-solids concentrations averaging less than $12 \mathrm{mg} / \mathrm{L}$.

A summary of selected chemical and physical properties and maximum contaminant levels (MCL's) set by the Rhode Island Department of Health (RIDOH) is shown in table 5. The analyses presented in table 5 were done in the laboratories of the USGS and the RIDOH. Most ground-water samples were collected from 1973 to 1986, and most surface-water samples were collected from 1978 to 1982. The following discussion of basin-water quality is based on results of analyses of samples from individual sites investigated by Dickerman and others (1989).

The ground water and surface water in the upper Wood River study area is suitable for most purposes. Water quality in the upper Wood River basin, much of which is undeveloped land managed by the State of Rhode Island (Arcadia Management Area; Wickaboxet Management Area), probably is representative of baseline or predevelopment ground-water quality in Rhode Island (Johnston and Barlow, 1988, p. 443). The upper Wood River ground-water reservoir was categorized as "Not Threatened" by the Rhode Island Department of Environmental Management (RIDEM), in its 1990 report to Congress on the state of the State's waters (Rhode Island Department of Environmental Management, 1990). The Not Threatened category is applicable to areas where ground water is presumed suitable for drinking and where nonpoint sources of contamination are not presently considered to threaten ground-water quality.

Because streamflow in the upper Wood River basin consists predominantly of ground-water runoff, the quality of surface water is directly related to ground-water quality. Most reaches of the Wood River and its tributaries are designated as "Class A" or "Class B" waterbodies (Rhode Island Department of Environmental Management, 1990, p. VB135). Class A waterbodies are suitable for use as a drinking-water supply (without treatment) and all other water uses; Class B waterbodies are suitable as a 
Table 5.--Summary of chemical and physical properties of ground water and surface water in the study area

[Data from Dickerman and others (1989); ground-water samples collected from 1973 to 1986; surfacewater samples collected from 1978 to 1982; units are in milligrams per liter, except as indicated;

--, no data available; $\mu \mathrm{S} / \mathrm{cm}$ at $25^{\circ} \mathrm{C}$, microsiemens per centimeter at 25 degrees Celsius; <, less than]

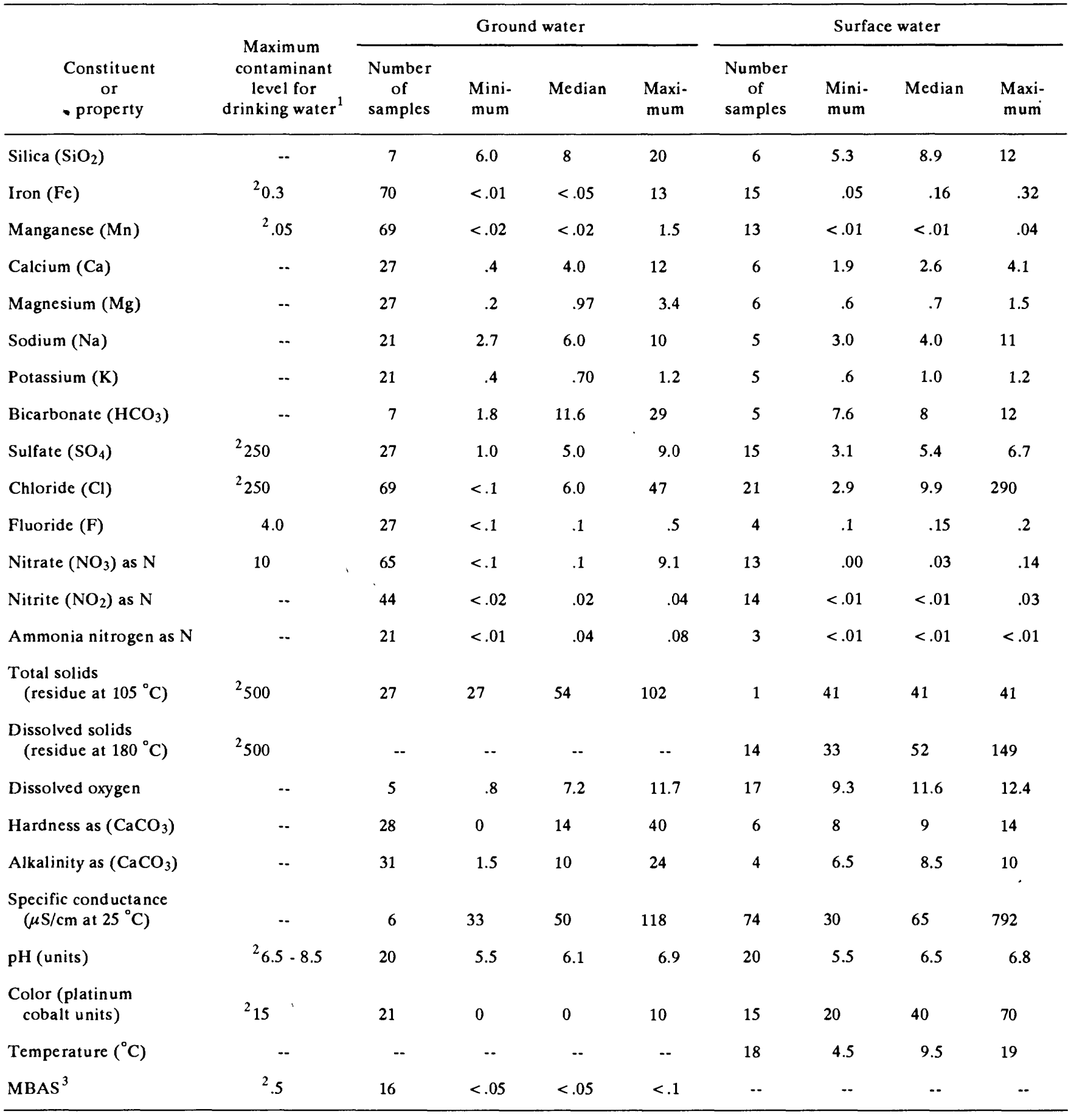

1 Maximum contaminant level for inorganic chemicals established for public water-supply systems by the U.S. Environmental Protection Agency and adopted by the R.I. Department of Health (1991).

${ }^{2}$ Secondary maximum contaminant level established for public water-supply systems by the U.S. Environmental Protection Agency and adopted by the R.I. Department of Health (1991).

${ }^{3}$ Detergents as methylene-blue-active substance (MBAS). 
drinking-water supply (with appropriate treatment), and for agricultural uses, primary-contact recreational activities (such as swimming), and fish and wildlife habitat. The water quality of the Wood River at Hope Valley is affected by substandard or failing septic systems and is designated as "Class C." Waterbodies designated as "Class $\mathrm{C}^{\text {" }}$ are suitable only for secondary-contact recreational activities (such as boating), fish and wildlife habitat, and industrial processes.

Both ground and surface water in the upper Wood River basin are soft; hardness is less than or equal to $40 \mathrm{mg} / \mathrm{L}$ as dissolved calcium carbonate. Dissolved-solid concentrations are less than $150 \mathrm{mg} / \mathrm{L}$; freshwater containing a dissolved-solids concentration of less than $250 \mathrm{mg} / \mathrm{L}$ can be considered to be of excellent quality (Irelan and Mendieta, 1964, p. K5). The principal cations--calcium, magnesium, sodium, and potassium--had median concentrations less than or equal to $6.0 \mathrm{mg} / \mathrm{L}$. The principal anions--bicarbonate, sulfate, and chloride--had median concentrations less than $12.0 \mathrm{mg} / \mathrm{L}$. Median pH values were 6.1 for ground water and 6.5 for surface water; $\mathrm{pH}$ values in the range of 6 to 8 are common for uncontaminated freshwater.

\section{Surface Water}

Water samples from streams at 12 sites in the central and southern parts of the study area were collected for water-quality analyses (table 5) during periods of low flow, when streamflow was composed primarily of ground-water runoff (Dickerman and others, 1989). Results of these analyses indicate that median values of most constituents and properties of surface water were comparable to the median values of constituents and properties of ground water from wells throughout the study area (table 5).

\section{Specific Conductance}

The median specific conductance of $65 \mu \mathrm{S} / \mathrm{cm}$ (table 5) is indicative of the generally excellent inorganic chemical quality of stream water in the upper Wood River basin. Specific conductance of streams in the study area was measured on October 14, 1976, and July 20,1990, during basinwide field surveys. Locations of stream sampling sites are shown in figure 16 , and measured values are summarized in table 6 . Specific conductance was less than $110 \mu \mathrm{S} / \mathrm{cm}$ in stream water at most sites for both the 1976 and 1990 surveys. Streams with specific-conductance values greater than $110 \mu \mathrm{S} / \mathrm{cm}$ include Roaring Brook (sites 15 and 16), an unnamed tributary to Baker Brook (site 17), Baker Brook (sites 18, 18A, and 19), and an unnamed tributary to the Wood River near Wyoming (site 24). Stream water having specific conductances greater than $110 \mu \mathrm{S} / \mathrm{cm}$ probably is affected by road salt. Effects of road salt are discussed in the next section on "Chloride."

Specific conductance can be used to estimate the concentration of dissolved solids (Hem, 1985, p. 67). Figure 17 is a graph showing the correlation between dissolved-solids concentration and specific conductance for streams in the upper Wood River study area. The relation between dissolved solids and specific conductance is expressed in the following equation:

$$
\begin{gathered}
\text { Dissolved-solids } \\
\text { concentration }
\end{gathered}=\begin{gathered}
24.3+0.55 \text { specific } \\
\text { conductance }
\end{gathered}
$$

where

dissolved-solids concentration is in $\mathrm{mg} / \mathrm{L}$, and specific conductance is in $\mu \mathrm{S} / \mathrm{cm}$.

The specific conductances used to determine the relation ranged from 35 to $220 \mu \mathrm{S} / \mathrm{cm}$. Although specific conductances measured for this study ranged from 30 to $792 \mu \mathrm{S} / \mathrm{cm}$, figure 17 can be used only to estimate dissolved-solids concentrations for waters with specific conductances of 35 to $220 \mathrm{mg} / \mathrm{L}$.

Specific conductance increases as stream discharge decreases. The variation in discharge and specific conductance in the Wood River at Hope Valley during a 3-month period in 1986 is shown in figure 18. During high streamflow, the addition of precipitation and overland flow, both of which have low specific conductance, reduces the stream specific conductance. For example, during June 13 through July 1,1986 , discharge generally decreased from the peak of $189 \mathrm{ft}^{3} / \mathrm{s}$ on June 13 to a low of $45 \mathrm{ft}^{3} / \mathrm{s}$ on July 1 , while specific conductance increased from 59 to $77 \mu \mathrm{S} / \mathrm{cm}$.

Figure 19 shows variations in concentrations of selected dissolved constituents in the Wood River at Arcadia (upstream site) and the Wood River at Hope Valley (downstream site) on November 13, 1978. Figure 19 indicates that concentrations of dissolved constituents are higher at the downstream site than at the upstream site. Total concentrations of principal ions in stream water increased from $32 \mathrm{mg} / \mathrm{L}$ at the upstream site to $50 \mathrm{mg} / \mathrm{L}$ at the downstream site. This increase in concentration from the upstream site to the downstream site is probably related to human 


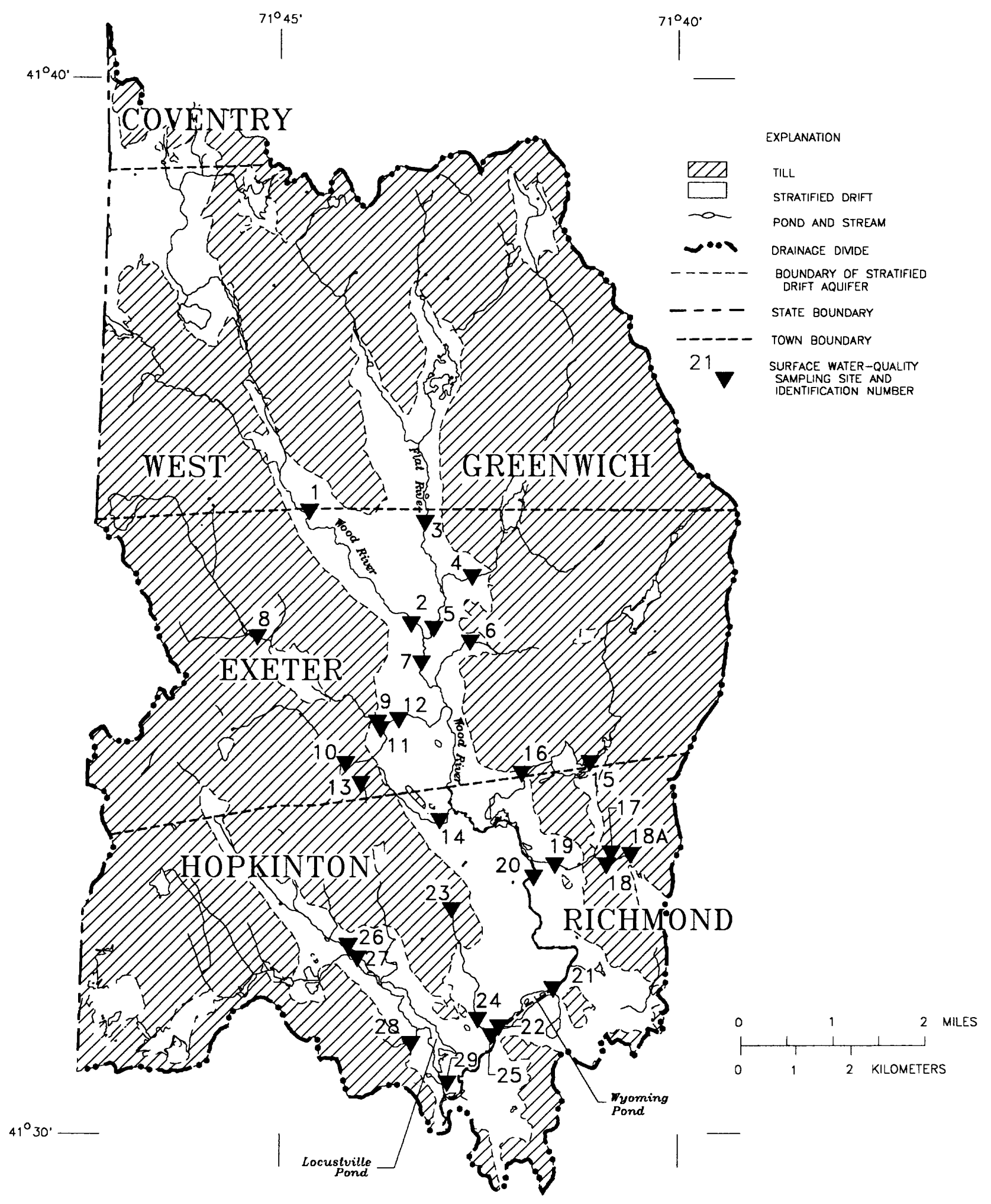

Figure 16.--Surface-water-quality sampling sites in the upper Wood River study area. 
Table 6.--Summary of specific conductance at selected surface-water sites

[Site locations a re shown in figure $16 ; \mu \mathrm{S} / \mathrm{cm}$, microsiemens per centimeter at 25 degrees Celsius; mi, miles; .-., no streamflow at time of measurement; NM, not measured]

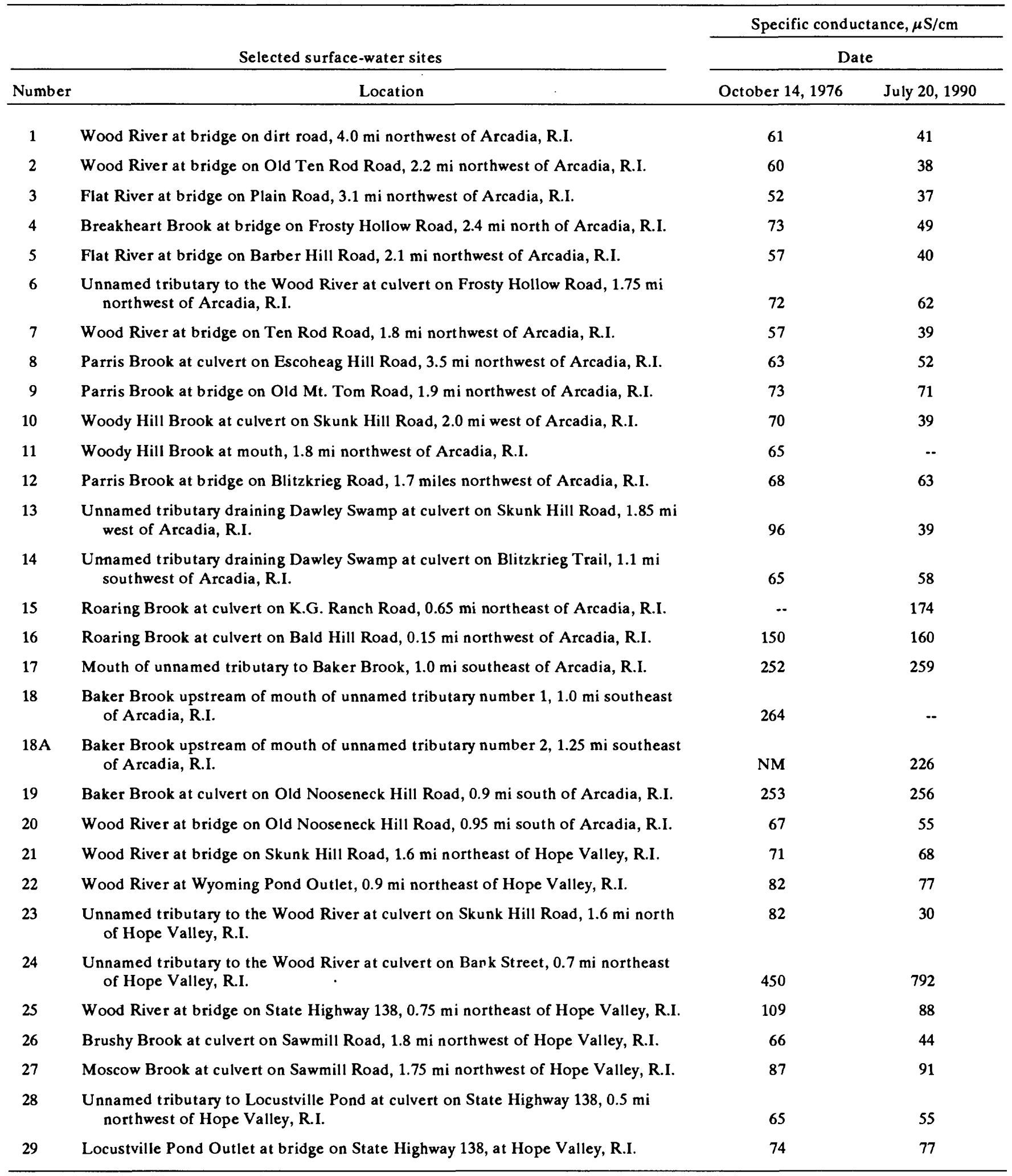




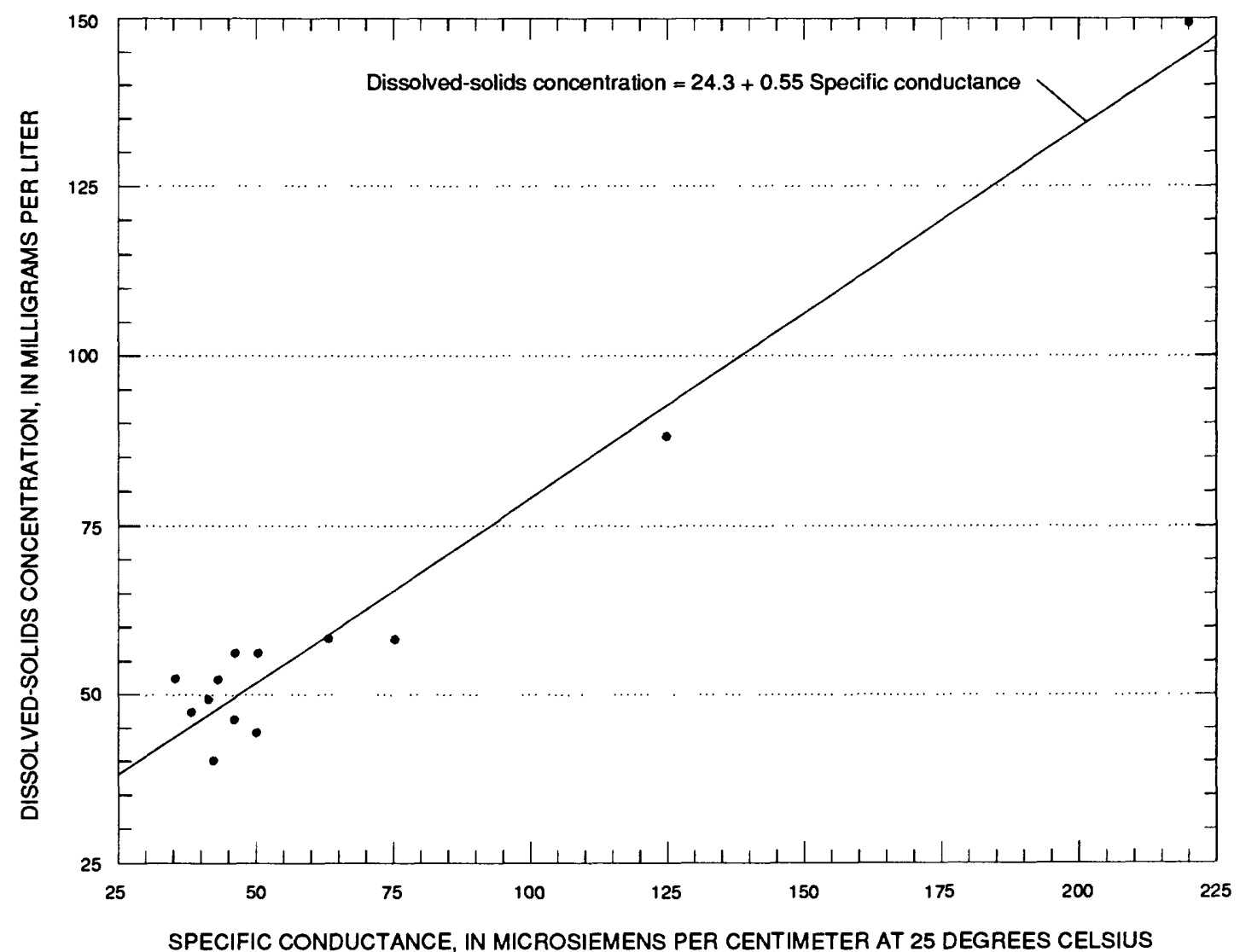

Figure 17.--Relation between dissolved-solids concentration and specific conductance for streams in the upper Wood River study area.

activities, such as application of deicing salts. Figure 19 indicates that the increases in the concentrations of sodium and chloride (salt constituents) were greatest relative to the total concentration of dissolved constituents and that concentrations of all other constituents remained nearly constant. The relative proportion of sodium in stream water increased from 12.4 percent $(4 \mathrm{mg} / \mathrm{L})$ at the Arcadia site to 22 percent $(11 \mathrm{mg} / \mathrm{L})$ at the Hope Valley site. The relative proportion of chloride in stream water increased from 17.3 percent $(5.6 \mathrm{mg} / \mathrm{L})$ at the Arcadia site to 30.1 percent $(15 \mathrm{mg} / \mathrm{L})$ at the Hope Valley site.

Continuous records of discharge (recorded every half hour) and specific conductance (recorded hourly) were collected at the streamflow-gaging station on the Wood River at Hope Valley, R.I., for water years 1978 through 1989. Trends in discharge and specific conductance at the Hope Valley site were evaluated by means of the Seasonal Kendall test (Hirsch and others, 1982). Results of the tests indicate that discharge has decreased slightly $(-6.5$ $\left.\left(\mathrm{ft}^{3} / \mathrm{s}\right) / \mathrm{yr}\right)$, whereas the specific conductance has increased slightly $(+1.1(\mu \mathrm{S} / \mathrm{cm}) / \mathrm{yr})$ over the 12 -year period of record. These results are consistent with the general relation described earlier; that is, a decrease in discharge causes an increase in specific conductance in the study area.

A flow-adjustment trend test (Smith and others, 1982) was used to compensate for changes in discharge that could mask a trend in specific conductance. This technique, generally called residual analysis, compares actual values with regression-estimated values. If processes supplying ions to a stream have not changed, then flow-adjusted specific conductance would be expected to fluctuate random- 


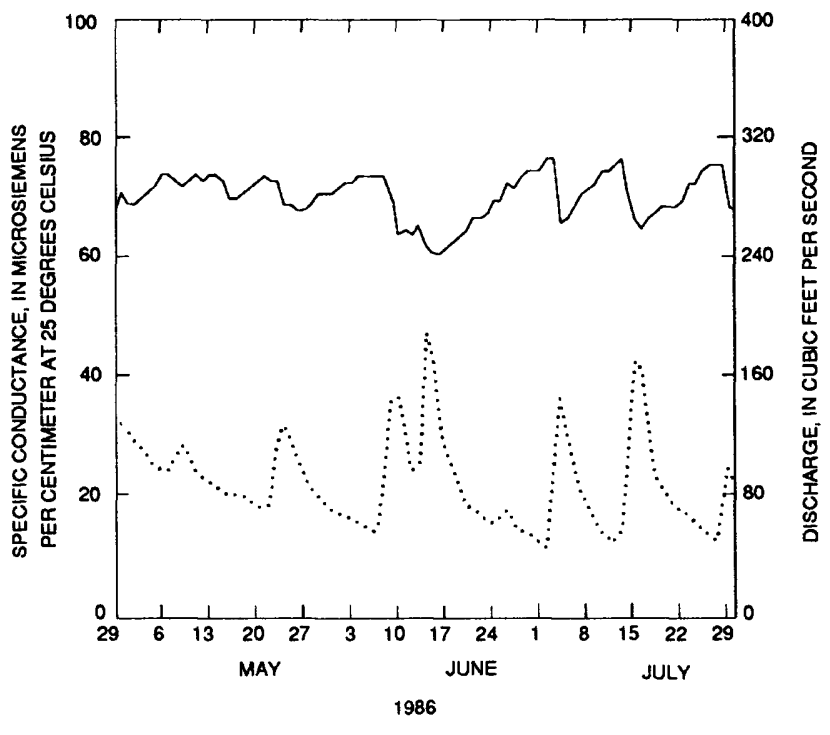

EXPLANATION

SPECIFIC CONDUCTANCE, IN MICROSIEMENS PER CENTIMETER AT 25 DEGREES CELSIUS

DISCHARGE, IN CUBIC FEET PER SECOND

Figure 18.--Specific conductance and stream discharge for the Wood River at Hope Valley, April 29-July 29, 1986.

ly about zero. A net change in the processes would cause an upward or downward trend in the flow-adjusted values; however, the reason for the variation would not be identified.

Results of the flow-adjusted test for specific conductance in streamflow at the Wood River at Hope Valley indicate a slight upward trend $(+0.8$ $(\mu \mathrm{S} / \mathrm{cm}) / \mathrm{yr})$. The specific cause of this increase was not identified in this study, but it may be related to changes in land-use practices or application of deicing salt.

\section{Chloride}

As part of the low-flow specific-conductance survey on July 20, 1990, a sample was collected at each site for determination of chloride concentration where specific conductance of the streamflow was greater than $150 \mu \mathrm{S} / \mathrm{cm}$. Data are summarized in table 7 for the six stream sites where chloride con- centration and specific conductance were measured. Water from site 24 , on an unnamed tributary to the Wood River, had the highest chloride concentration $(290 \mathrm{mg} / \mathrm{L})$ and specific conductance $(792 \mu \mathrm{S} / \mathrm{cm})$. The chloride concentration at this site was higher than the RIDOH secondary MCL (SMCL) of 250 $\mathrm{mg} / \mathrm{L}$ for public-water systems. A salt-storage facility upstream from sampling site 24 is the most probable cause of the high chloride concentration and specific conductance measured in the stream water, which consists primarily of ground-water runoff.

Samples from sites 15 and 16, on Roaring Brook, and sites 17, 18A, and 19, on Baker Brook and one of its tributaries, also had chloride concentrations and specific conductances considerably higher than the respective medians of $9.9 \mathrm{mg} / \mathrm{L}$ and $65 \mu \mathrm{S} / \mathrm{cm}$ for streams in the upper Wood River study area (table 5). Chloride concentrations ranged from 40 to $72 \cdot \mathrm{mg} / \mathrm{L}$ and specific conductances ranged from 160 to 259 $\mu \mathrm{S} / \mathrm{cm}$ in stream water at these sites. Elevated values at these sites indicate that the quality of the groundwater runoff is probably affected by the application of deicing salt, because the sites are near roads that are salted.

\section{Ground Water}

Water samples from 59 wells were tested for iron and manganese. Both constituents are generally present in concentrations less than the RIDOH SMCL shown in table 5 for public water-supply systems. Locally, however, water from several wells contained iron in concentrations at or above the SMCL of $0.3 \mathrm{mg} / \mathrm{L}$ : in the central part of the study area, EXW $423(1.6 \mathrm{mg} / \mathrm{L})$ and EXW $424(0.3 \mathrm{mg} / \mathrm{L})$; and in the southern part of the study area, HOW 241 $(0.5 \mathrm{mg} / \mathrm{L})$, RIW $131(0.3 \mathrm{mg} / \mathrm{L})$, and RIW 711 (13 $\mathrm{mg} / \mathrm{L})$. Water from these wells also contained manganese in concentrations equal to or greater than the RIDOH SMCL $(0.05 \mathrm{mg} / \mathrm{L})$ : EXW $423(0.05 \mathrm{mg} / \mathrm{L})$, EXW $424(0.06 \mathrm{mg} / \mathrm{L})$, HOW $241(1.5$ and $0.4 \mathrm{mg} / \mathrm{L})$, RIW $131(0.05 \mathrm{mg} / \mathrm{L})$, and RIW $711(0.27 \mathrm{mg} / \mathrm{L})$. Treatment may be desirable for ground water that is to be used for public drinking-water supply where concentrations of iron and manganese are greater than the SMCL's of $0.3 \mathrm{mg} / \mathrm{L}$ and $0.5 \mathrm{mg} / \mathrm{L}$, respectively.

In Rhode Island, elevated nitrogen concentrations in ground water are commonly attributed to the land application of fertilizer. Septic-tank discharge also can cause high nitrate concentrations. Water samples from all 59 wells tested for nitrate $\left(\mathrm{NO}_{3}\right.$ as N) were less than the MCL of $10 \mathrm{mg} / \mathrm{L}$ for public 


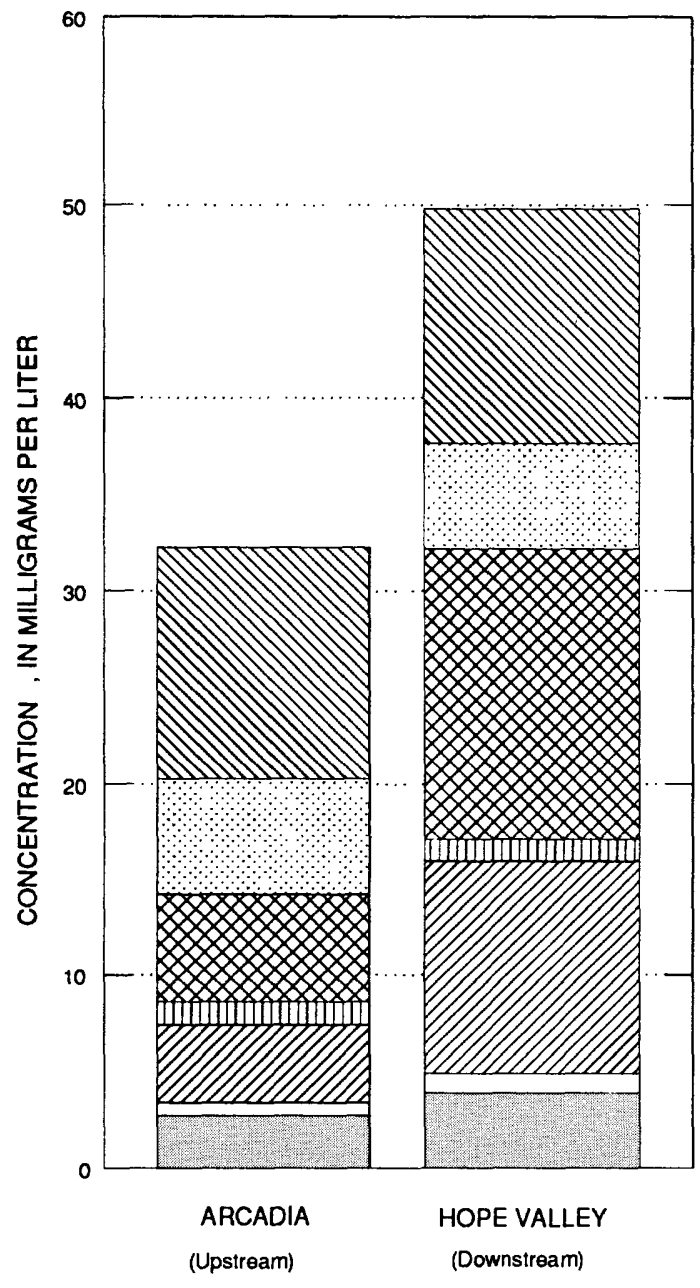

EXPLANATION

BICARBONATE

SULFATE

CHLORIDE

IIII POTASSIUM

SODIUM

MAGNESIUM

CALCIUM

Figure 19.--Concentrations of selected dissolved constituents for the Wood River at Arcadia and at Hope Valley, November 13, 1978. water-supply systems (table 5). The only sample with a concentration approaching the MCL for nitrate was from well HOW $116(9.1 \mathrm{mg} / \mathrm{L})$, on the eastern side of Locustville Pond.

The median concentration of chloride in 69 samples of ground water in the study area (table 5) was $6.0 \mathrm{mg} / \mathrm{L}$. Twenty-five percent of the samples had chloride concentrations less than $3.0 \mathrm{mg} / \mathrm{L}$, which indicates that the baseline concentration is low. The maximum chloride concentration measured in these samples $(47 \mathrm{mg} / \mathrm{L})$ is below the RIDOH SMCL of $250 \mathrm{mg} / \mathrm{L}$.

Chloride concentrations exceeding the 75 th percentile $(14.5 \mathrm{mg} / \mathrm{L})$ are probably the result of human activities. Chloride concentrations greater than 22.0 $\mathrm{mg} / \mathrm{L}$ (90th percentile) were measured in groundwater samples from wells near roads that are salted during winter. For example, samples from EXW 424, which is adjacent to Route 165 in Exeter, had a chloride concentration of $30 \mathrm{mg} / \mathrm{L}$. Samples from other wells having chloride concentrations above the 90th percentile include RIW 711, near Route 3 (Nooseneck Hill Road) in Richmond (chloride 47 $\mathrm{mg} / \mathrm{L}$ ), and HOW 137, adjacent to Skunk Hill Road in Hopkinton (chloride $25 \mathrm{mg} / \mathrm{L}$ ). Although additional analyses would be needed to determine whether a statistically significant relation exists, these data indicate that highway salting has affected concentrations of chloride in water in some wells in the study area.

Water samples from three 8-in. test wells in Exeter and two wells in Richmond were analyzed for selected metals and synthetic organic compounds. Table 8 indicates that concentrations of these constituents in water samples from these wells were less than the MCL's established by the RIDOH. In fact, barium was the only constituent measured whose concentrations were greater than the minimum detection limit for the particular laboratory technique used.

Although table 8 indicates that contamination from synthetic organic compounds is not a widespread problem, some local degradation of groundwater quality as a result of human activities has occurred in the upper Wood River study area. During the late 1960's and late 1970's, leakage from gasoline-storage tanks beneath gas stations in the Canob Park area resulted in contamination of ground water by several volatile organic compounds. Within the plume of contaminated ground water, the maximum concentrations of volatile organic compounds were as follows: benzene, $3,200 \mu \mathrm{g} / \mathrm{L}$; toluene, 2,600 $\mu \mathrm{g} / \mathrm{L}$; xylene, $8,600 \mu \mathrm{g} / \mathrm{L}$; and ethylbenzene, 2,800 $\mu \mathrm{g} / \mathrm{L}$. These contaminants were detected in water 
Table 7.--Summary of dissolved-chloride concentrations and specific conductance at selected surface-water sites

$[\mu \mathrm{S} / \mathrm{cm}$, microsiemens per centimeter at 25 degrees Celsius; $\mathrm{mg} / \mathrm{L}$, milligrams per liter; mi, miles]

\begin{tabular}{|c|c|c|c|}
\hline \multicolumn{2}{|r|}{ Selected surface-water sites } & \multirow{2}{*}{$\begin{array}{l}\text { Dissolved- } \\
\text { chloride } \\
\text { concentration } \\
(\mathrm{mg} / \mathrm{L})\end{array}$} & \multirow{2}{*}{$\begin{array}{c}\text { Specific } \\
\text { conductance } \\
(\mu \mathrm{S} / \mathrm{cm})\end{array}$} \\
\hline Number & Location & & \\
\hline 15 & $\begin{array}{l}\text { Roaring Brook at culvert on K.G. Ranch Road, } 0.65 \mathrm{mi} \\
\text { northeast of Arcadia, R.I. }\end{array}$ & 40 & 174 \\
\hline 16 & $\begin{array}{l}\text { Roaring Brook at culvert on Bald Hill Road, } 0.15 \mathrm{mi} \\
\text { northwest of Arcadia, R.I. }\end{array}$ & 44 & 160 \\
\hline 17 & $\begin{array}{l}\text { Mouth of unnamed tributary to Baker Brook, } 1.0 \mathrm{mi} \\
\text { southeast of Arcadia, R.I. }\end{array}$ & 59 & 259 \\
\hline $18 \mathrm{~A}$ & $\begin{array}{l}\text { Baker Brook upstream of mouth of unnamed tributary } \\
\text { number } 2,1.25 \text { mi southeast of Arcadia, R.I. }\end{array}$ & 71 & 226 \\
\hline 19 & $\begin{array}{l}\text { Baker Brook at culvert on Old Nooseneck Hill Road, } \\
0.9 \text { mi south of Arcadia, R.I. }\end{array}$ & 72 & 256 \\
\hline 24 & $\begin{array}{l}\text { Unnamed tributary to the Wood River at culvert on Bank } \\
\text { Street, } 0.7 \mathrm{mi} \text { northeast of Hope Valley, R.I. }\end{array}$ & 290 & 792 \\
\hline
\end{tabular}

samples from wells north of Route 138 during a 1982 study (D.J. Pernice, U.S. Environmental Protection Agency, written commun., April 1990).

\section{GROUND-WATER-DEVELOPMENT ALTERNATIVES}

The effects of alternative schemes of groundwater development on ground-water levels and streamflow in the upper Wood River ground-water reservoir were evaluated by means of a one-layer, two-dimensional ground-water-flow model. The model was used to simulate the interaction between surface water and ground water in the stream-aquifer system. Steady-state simulations of theoretical ground-water withdrawals were made for long-term average annual conditions (1942-89) and drought conditions (1963-66).

\section{Simulation of Ground-Water Flow}

When simulating a ground-water system, one must understand and conceptualize the natural system. To increase understanding of the groundwater-flow system in the upper Wood River study area, the natural system was conceptualized and later analyzed by means of a digital model.

\section{Conceptual Model}

A conceptual model of the stream-aquifer system in the upper Wood River ground-water reservoir was developed from previously published geohydrologic data (Dickerman and others, 1989). The goal in developing the upper Wood River model was to keep the conceptual model as simple as possible while retaining the essential features of the real stream-aquifer system. Simplifying assumptions included in the conceptual model flow system are as follows:

1. Ground-water flow in the stratified-drift aquifer is horizontal; no ground water flows either to or from the underlying bedrock. Although groundwater flow in the stratified drift is not strictly horizontal, this assumption applies reasonably well to most of the model area. The result of this assumption is that the model cannot accurately simulate ground-water heads in areas where vertical flow is significant. In reality, flow from bedrock to stratified drift does occur. This leakage to 
Table 8.--Concentrations of selected metals and synthetic organic compounds in ground water in the study area

[Results of analyses are in micrograms per liter; --, no data available; <, less than; analyzed by Rhode Island Department of Health]

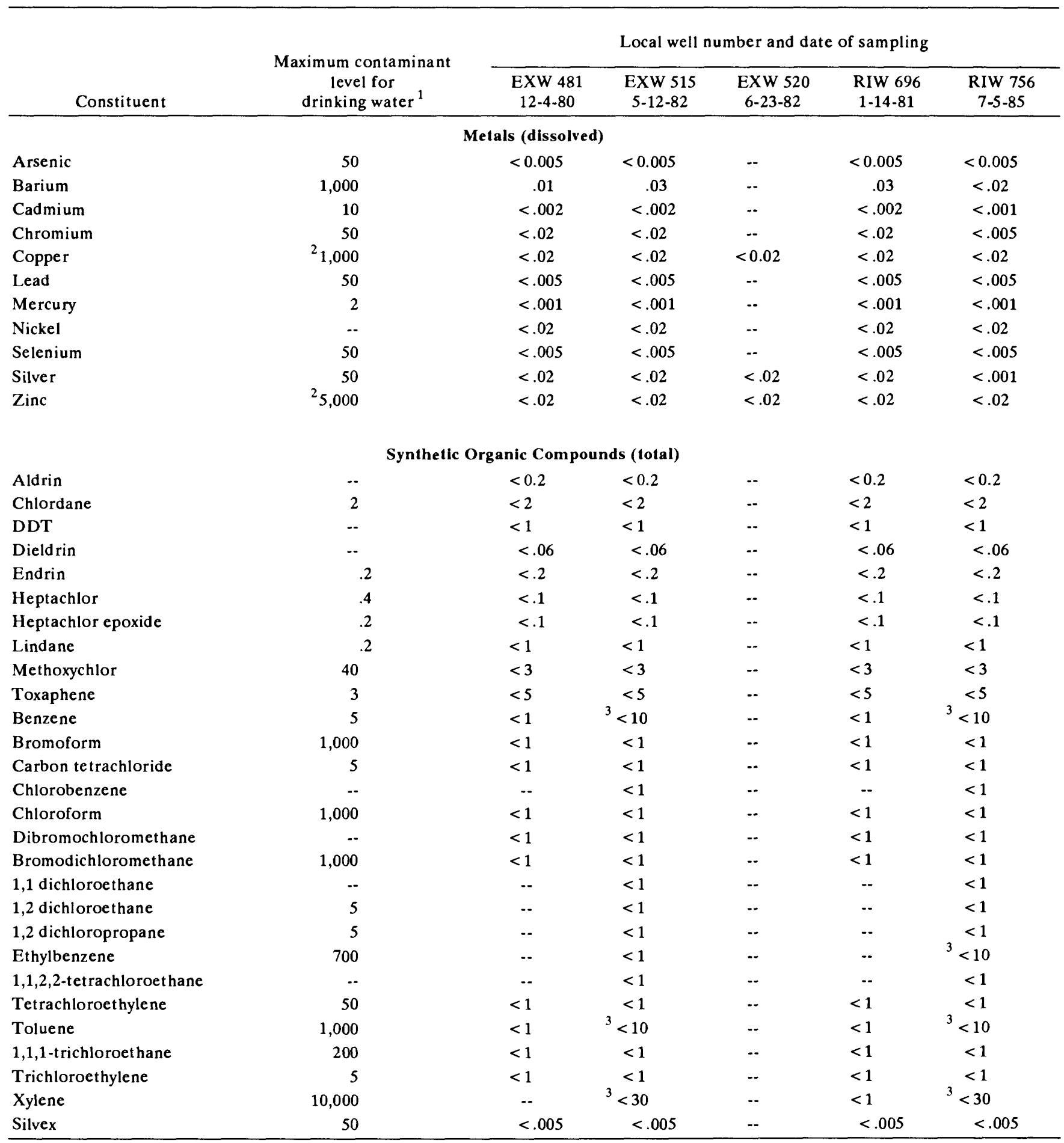

${ }^{1}$ Maximum contaminant level established by the U.S. Environmental Protection Agency and adopted by the R.I. Department of Health (1991) for treated drinking water, except as indicated.

${ }^{2}$ Secondary maximum contaminant level established by the U.S. Environmental Protection Agency and adopted by the R.I. Department of Health (1991) for treated drinking water.

${ }^{3}$ Detection limit changed due to sample dilution. 
or from the underlying bedrock aquifer was considered to be small. Therefore, bedrock was not included in the ground-water-flow model.

2. Recharge from precipitation directly on the stratified-drift aquifer was uniformly distributed over the model area, except in discharge areas such as swamps and streams. Recharge was applied at a rate of $29 \mathrm{in} / \mathrm{yr}$ for long-term average annual conditions, which is equivalent to a rate of about $21 \mathrm{in} / \mathrm{yr}$ if recharge were evenly distributed over the entire area. Recharge was reduced by 25 percent to simulate drought. Reduced recharge was based on comparison of long-term average annual and drought streamflows.

3. Recharge to the stratified drift from till/bedrock uplands was applied along the perimeter of the model near the geologic contact between the till and the stratified drift. Recharge from uplands was applied at a rate of $29 \mathrm{in} / \mathrm{yr}$ and evenly spread over active model cells adjacent to the till/bedrock areas not drained by streams. In upland areas drained by streams, no recharge was input to the model because data were lacking to confirm that small tributary streams were losing water to the underlying stratified-drift aquifer. Therefore, all tributary streams were assumed to be gaining streams.

4. The elevation of surface water in ponds and streams does not vary with time.

5. Ground water discharges from the aquifer to surface-water bodies through leaky ponds and streambeds, by evaporation and transpiration, and to pumped wells.

6. Ground-water evaporation and transpiration decreases linearly with depth of water table from a maximum at land surface to zero at $4 \mathrm{ft}$ or more below land surface. The evaporation and transpiration rate used in the model is $23.7 \mathrm{in} / \mathrm{yr}$, as determined by using the Thornthwaite method (Thornthwaite and Mather, 1957).

7. All pumped wells are considered not only to be screened throughout the entire saturated thickness of the aquifer but also to be 100-percent efficient. Maximum allowable cell drawdown was limited to 25 percent of the initial saturated thickness to compensate for idealized well-construction characteristics.

Although these basic assumptions do not always represent actual field conditions of the streamaquifer system, the authors believe that any deviations from them probably do not introduce large errors in conceptualization of the system or in digital simulations based on this conceptual model.

The part of the upper Wood River study area selected for simulation consists of $8 \mathrm{mi}^{2}$ of stratified drift; its boundary is shown in figure 1. The natural syste $m$ and corresponding idealized conceptual model of the steady-state ground-water-flow system are shown schematically in figure 20 .

\section{Digital Model}

Digital models of ground-water flow are widely used in the analysis and management of water resources. A digital model is a computer program designed to solve equations that mathematically represent ground-water flow. A calibrated model can be used to evaluate the effects of stresses imposed on the stream-aquifer system. Accurate simulation of the flow system is essential for anticipating response of the aquifer to applied stresses for stream-aquifer systems. The seven simplifying assumptions of the conceptual model guided the design of input and output parameters for the digital model used to represent the complex geohydrology of the upper Wood River stream-aquifer system.

A finite-difference model (MODFLOW), developed by McDonald and Harbaugh (1988), was used in this study to simulate the ground-water-flow system and its response to imposed stresses. The model is based on a block-centered, finite-difference method to approximate the differential equations that describe the flow of ground water. Solution of these equations requires subdivision of the model area into a grid of rectangular blocks called cells; in this study each cell was $500 \mathrm{ft}$ on a side. The grid network (fig. 21) of the upper Wood River model consists of 91 rows and 49 columns. Only the 1,500 cells representing the stratified-drift aquifer are considered "active" and are involved in the numerical computations.

A finite-difference equation that approximates flow in the block is evaluated at each cell of the grid, and the set of equations for the entire system is solved simultaneously. The solution technique used in the model is the strongly implicit procedure (SIP) developed by Weinstein and others (1969).

\section{Boundary conditions}

Accurate representation of model boundaries is an important aspect of model construction. Boundary conditions in the upper Wood River ground- 


\section{A. Natural System}
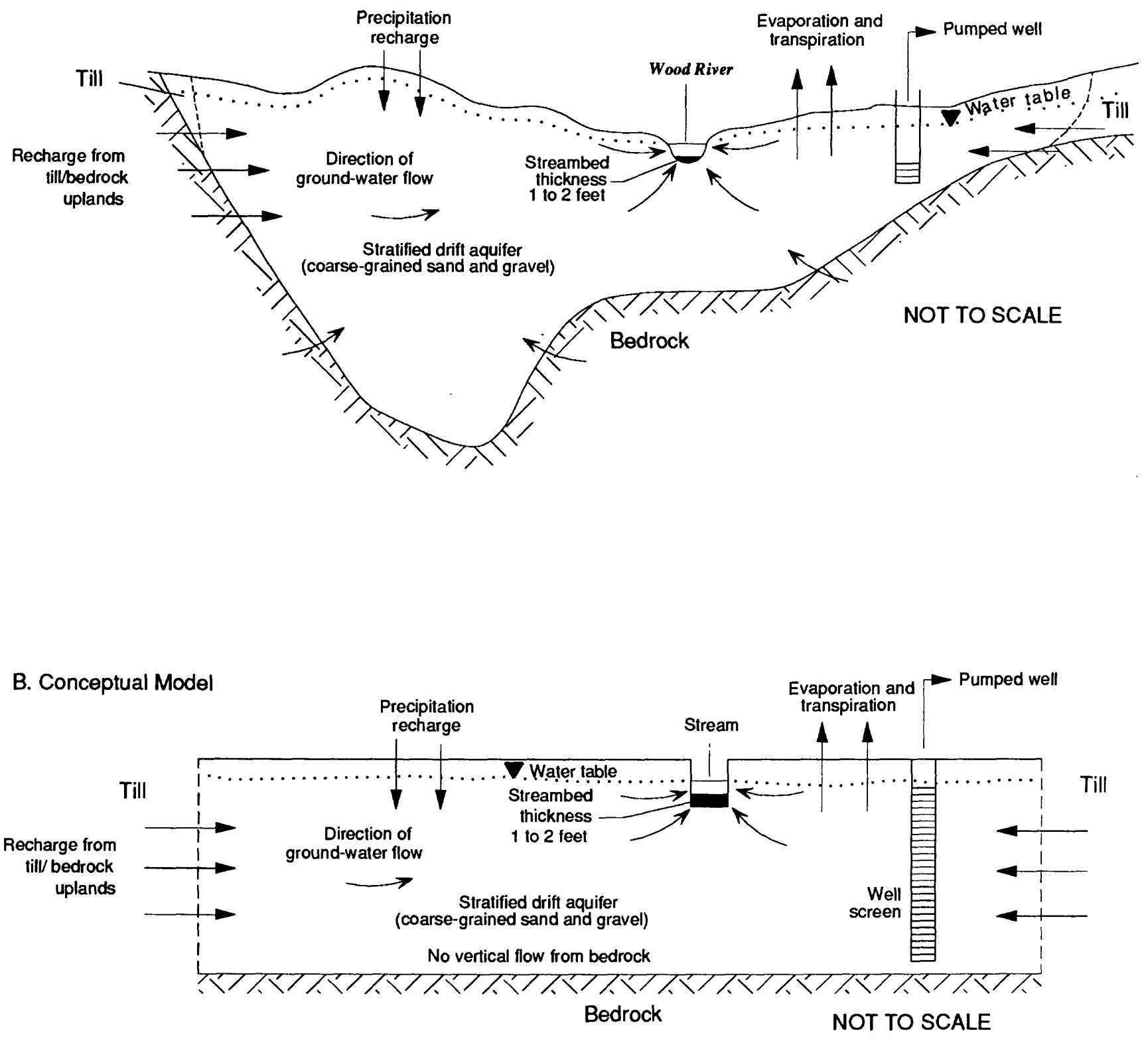

Figure 20.--Natural system and idealized conceptual model of steady-state ground-water flow. 


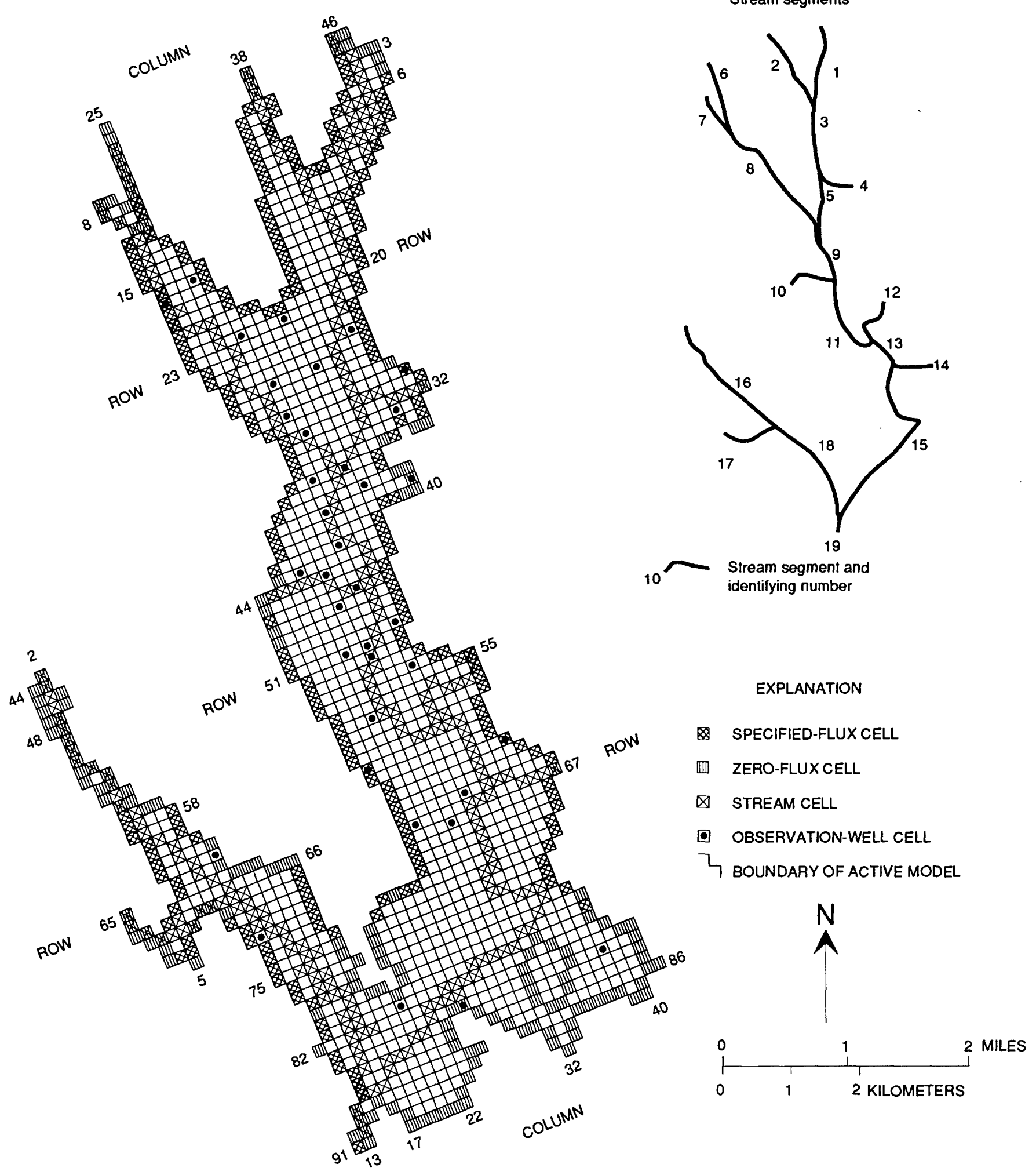

Figure 21.--Finite-difference grid and identification of stream segments for the upper Wood River ground-water model. 
water model are shown in figure 21. Most of the northern, eastern, and western model boundaries coincide with the geologic contact between the stratified-drift aquifer and the till-covered bedrock valley walls. Flow across this geologic contact was simulated in the model as a specified flux into the first cell within the stratified drift. Recharge from till/bedrock uplands was simulated as positive specified fluxes by means of the well package in MODFLOW. Most of the southern edge of the model was simulated as a zero-flux boundary along the drainage divide to the streamflow-gaging station, or where the saturated thickness of the stratified drift thins to less than $20 \mathrm{ft}$. Underflow from the basin was simulated along the southern boundary at the gaging station as a negative specified flux.

The bottom boundary of the aquifer is the contact between the highly permeable stratified drift and the less permeable till-covered bedrock. In the model, this contact was simulated as a no-flow boundary. The top boundary of the aquifer is the water table and is computed by the model.

\section{$\underline{\text { Initial conditions and input parameters }}$}

The first step in modeling was to select a period of time during which recharge to the aquifer, groundwater runoff, and water-table altitude represented long-term average annual or steady-state conditions. Monthly data collected for this study from 1982 through 1985 show that streamflow and water-level data from December 1982 were closest to (about 3 percent below) long-term average annual conditions. The December 1982 period was selected as representative of steady-state conditions and used for calibrating the steady-state simulation.

The flow equations require that the hydraulic properties of the aquifer be defined for the active model area. In the upper Wood River model, values were assigned to appropriate cells for hydraulic conductivity of the aquifer, conductance (streambed hydraulic conductivity multiplied by river width and reach length, divided by streambed thickness), elevation of the top and bottom of the streambed, elevation of the stream surface, recharge, evaporation and transpiration, ground-water inflow from till/bedrock uplands, aquifer-bottom altitude, starting-head altitude, and land-surface elevation. Geographic Information System (GIS) technology was used to simplify input of model data arrays.

Horizontal hydraulic conductivities of the aquifer that were used in the model are shown in figure 22. Initial values of hydraulic conductivity were determined from aquifer tests and lithologic logs. Where no other information was available, horizont al hydraulic conductivities were estimated from the following equation:

$$
\mathrm{K}=\frac{\mathrm{V} \theta}{\mathrm{I}}
$$

where

$$
\begin{aligned}
& \mathrm{K} \text { is horizontal hydraulic conductivity } \\
& \left(\mathrm{LT}^{-1}\right) \text {; } \\
& \mathrm{V} \text { is velocity determined from aquifer } \\
& \text { tests }\left(\mathrm{LT}^{-1}\right) \text {; } \\
& \theta \text { is porosity determined from labor- } \\
& \text { atory values of Pawcatuck River } \\
& \text { basin sediments (dimensionless); } \\
& \text { and } \\
& \mathrm{I} \text { is gradient from water-table map } \\
& \text { (dimensionless). }
\end{aligned}
$$

Some values of horizontal hydraulic conductivity were modified during model calibration. Horizontal hydraulic conductivities shown in figure 22 are the final result of model calibration.

Streams and ponds simulated in the model are identified in figure 21 as stream cells. Because aquifer cells in the model are wider than natural ponds or streams, input to the model was adjusted to compensate for actual pond or stream width. Effective streambed hydraulic conductivities derived from analysis of aquifer-test data were used to calculate flow between stream cells and the aquifer. Streams and ponds were simulated as a leaky boundary. Initially, vertical hydraulic conductivities of the streambed were set equal to vertical hydraulic conductivities determined from aquifer tests near the stream, and streambed thickness was set at $1 \mathrm{ft}$.

Stream-aquifer interconnection in the model is simulated by means of a stream-routing package developed for MODFLOW (Prudic, 1989). This package was used in place of the river package of MODFLOW because it routes streamflow through the model; whenever simulated flow in the stream ceases, the simulation of induced infiltration to the aquifer also ceases.

The recharge rate from precipitation to the stratified-drift aquifer was applied at the long-term average annual rate of $29 \mathrm{in} / \mathrm{yr}$, which is equivalent to a rate of $21 \mathrm{in} / \mathrm{yr}$ when distributed evenly. The December 1982 water-table map (fig. 4) was used to estimate water-table altitude at each cell. Surfacewater elevations of ponds and streams were estimated by interpolating between topographic contours shown in figure 2 . 


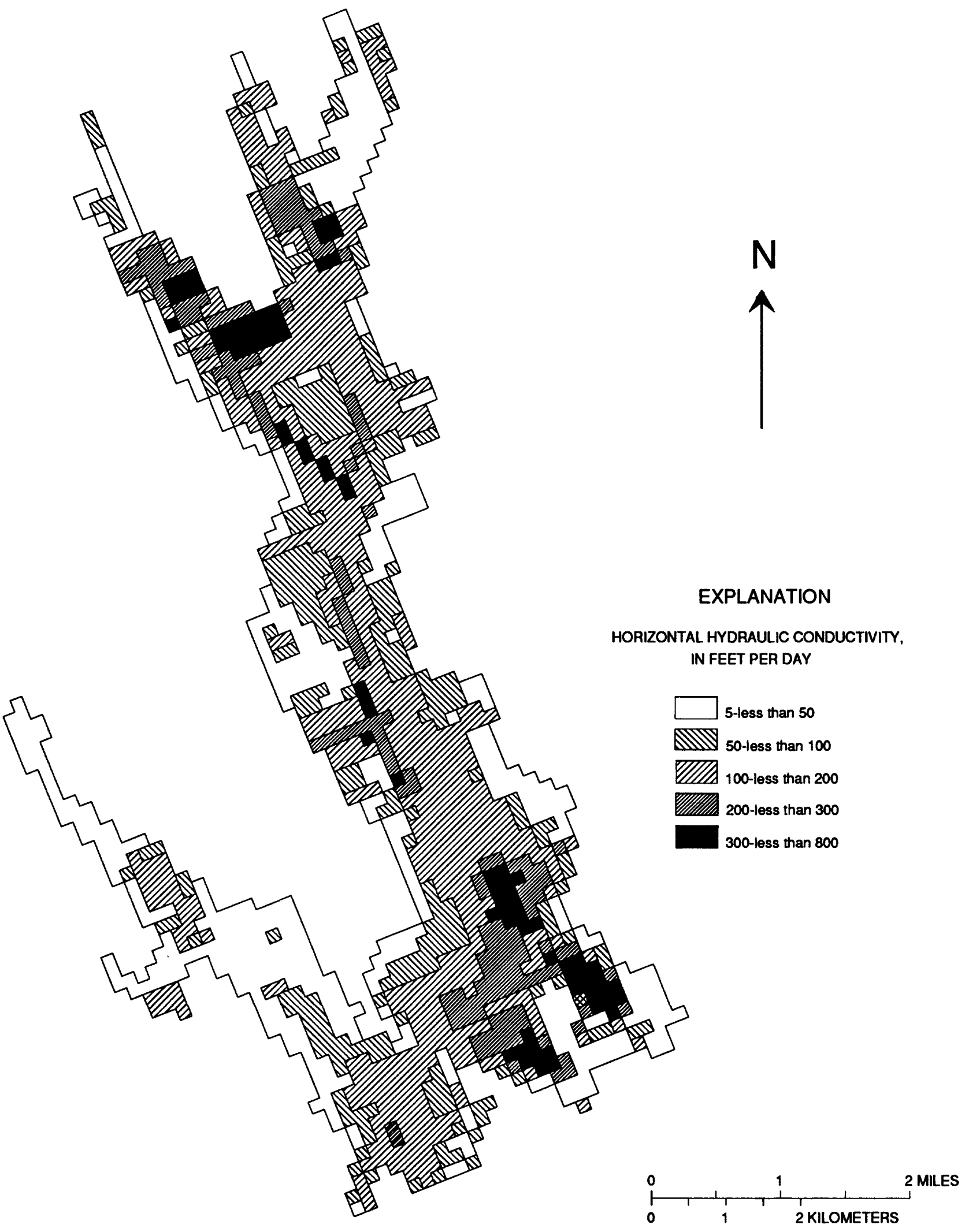

Figure 22.--Horizontal hydraulic conductivity used in the ground-water model of the upper Wood River stratified-drift aquifer. 
Calibration of a ground-water-flow model refers to the process of adjusting input parameters until differences between computed and measured watertable altitudes are within acceptable limits. During calibration, bottom altitudes and hydraulic conductivities of the aquifer were modified near till/bedrock contacts along the western and eastern sides of the model, where data were sparse, until computed water-table altitudes were within acceptable limits. Acceptability of the upper Wood River model was determined by comparing computed and measured water-table altitudes and by comparing simulated streamflow with long-term streamflow measured at Hope Valley and estimated at Arcadia.

The first step in calibrating the steady-state model of the upper Wood River ground-water reservoir was to compare the computed water-table altitude with the long-term average annual water-table altitude measured in Exeter observation well EXW 6 (fig. 2). This comparison showed that the computed water-table altitude is $2.6 \mathrm{ft}$ below the long-term average annual water-table altitude at this well. Well EXW 6 is near the Wood River in the central part of the basin. This well, which has been measured monthly since December 1948, is part of the network of Federal observation wells in Rhode Island.

The next step in calibrating the steady-state model was to compare computed water-table altitudes with water-level measurements made in $37 \mathrm{ob}$ servation wells in December 1982. Differences between computed and measured water-table altitudes ranged from -6.6 to $11.4 \mathrm{ft}$ (table 9). The mean absolute error of the residuals of these differences is $3.0 \mathrm{ft}$, and the root mean square error is $3.7 \mathrm{ft}$. Differences between computed and measured water-table altitudes were less than $3 \mathrm{ft}$ at 57 percent of the observation-well cells and less than $5 \mathrm{ft}$ at 86 percent of the cells. Final steady-state simulated water-table contours for these computed water-table altitudes (for nonpumping, long-term average annual conditions) are shown in figure 23 . Water-table altitudes for the 37 control wells are given in figure 23 so that measured data can be compared with simulated contours. Figure 23 can also be used to compare the position of the water table under nonpumping conditions to later simulations in which the aquifer is stressed by pumping from wells.

The third step in calibrating the steady-state model was to compare computed streamflow with long-term average annual streamflow. Streams in the upper Wood River model were divided into 19 stream segments (fig. 21). Ponded areas along streams also were modeled as stream cells. Initial values of effective streambed hydraulic conductivity from aquifer tests produced simulated streamflow that was too high; thus values were adjusted until streamflow was within acceptable limits of $1 \mathrm{ft}^{3} / \mathrm{s}$. Final effective streambed hydraulic conductivities used in the calibrated model ranged from 0.5 to $5 \mathrm{ft} / \mathrm{d}$ for a streambed thickness of 1 or $2 \mathrm{ft}$. A streambed thickness of $2 \mathrm{ft}$ was used in areas (93 stream cells) that were ponded behind dams where bottom sediment is thicker than elsewhere. Most stream cells (199) were assigned a streambed thickness of $1 \mathrm{ft}$.

Results of the final nonpumping steady-state simulation show that simulated streamflow is in close agreement with long-term average annual streamflow throughout the model area. Simulated steady-state streamflow from the model at the upstream gaging station on the Wood River at Arcadia was $76 \mathrm{ft}^{3} / \mathrm{s}$ (estimated streamflow $77 \mathrm{ft}^{3} / \mathrm{s}$ ) and at the downstream station on the Wood River near Hope Valley was 157 $\mathrm{ft}^{3} / \mathrm{s}$ (measured streamflow $156 \mathrm{ft}^{3} / \mathrm{s}$ ).

The final step in the model calibration was to determine whether simulated steady-state inflows and outflows of water to the model area were in balance. The mass-balance calculation checks the numerical accuracy of the model solution and should be less than 0.1 percent (Konikow, 1978). The upper Wood River model had a mass-balance discrepancy of 0.00 percent for the steady-state model, indicating no significant errors in numerical computations; the model was considered calibrated and acceptable for use in pumping simulations. The simulated steadystate ground-water budget (table 10) indicates that the source of recharge (inflow) to the stratified-drift aquifer is 50 percent precipitation, 43 percent ground-water inflow from till/bedrock uplands, and 7 percent stream infiltration from naturally losing stream reaches under long-term average annual nonpumping conditions.

\section{Sensitivity analysis}

Limitations of the conceptual model were assessed by means of an analysis of the sensitivity of the model to changes in model input. Principal input parameters were varied within the probable range of expected values for each parameter. The analysis provides a measure of the sensitivity of model results to changes in values of key parameters and, thus, a check on the reasonableness of the calibrated steadystate model. 
Table 9.--Measured and computed water-table altitudes for selected observation wells, December 1982

\begin{tabular}{|c|c|c|c|c|}
\hline \multicolumn{2}{|c|}{ Cell } & \multicolumn{2}{|c|}{$\begin{array}{c}\text { Water-table altitude, in feet } \\
\text { above sea level }\end{array}$} & \multirow{2}{*}{$\begin{array}{l}\text { Water-table } \\
\text { difference, } \\
\text { in feet }\end{array}$} \\
\hline Row & Column & Measured & Computed & \\
\hline 16 & 27 & 167.6 & 172.9 & -5.3 \\
\hline 17 & 24 & 159.5 & 160.3 & -.8 \\
\hline 22 & 29 & 142.4 & 146.1 & -3.7 \\
\hline 22 & 33 & 144.2 & ${ }^{a} 149.0$ & -4.8 \\
\hline 25 & 38 & 140.9 & 142.7 & -1.8 \\
\hline 27 & 30 & 134.8 & 135.8 & -1.0 \\
\hline 27 & 34 & $140: 4$ & 137.9 & 2.5 \\
\hline 30 & 30 & 131.2 & 131.6 & -.4 \\
\hline 30 & 41 & 174.3 & ${ }^{\mathrm{a}} 172.0$ & 2.3 \\
\hline 32 & 31 & 128.4 & 129.7 & -1.3 \\
\hline 33 & 39 & 163.0 & 163.2 & -.2 \\
\hline 36 & 30 & 127.6 & 130.3 & -2.7 \\
\hline 36 & 33 & 126.2 & 126.3 & -.1 \\
\hline 38 & 34 & 125.6 & 126.6 & -1.0 \\
\hline 39 & 30 & 126.9 & 124.3 & 2.6 \\
\hline 39 & 38 & 195.4 & ${ }^{\mathrm{a}} 184.0$ & 11.4 \\
\hline 42 & 30 & 125.9 & 121.9 & 4.0 \\
\hline 43 & 26 & 127.6 & 129.0 & -1.4 \\
\hline 44 & 28 & 126.3 & 123.7 & 2.6 \\
\hline 46 & 30 & 123.2 & 120.4 & 2.8 \\
\hline 47 & 28 & 125.7 & 121.9 & 3.8 \\
\hline 50 & 32 & 133.8 & ${ }^{a}{ }_{136.8}$ & -3.0 \\
\hline 51 & 29 & 120.7 & 117.4 & 3.3 \\
\hline 51 & 27 & 121.1 & 119.4 & 1.7 \\
\hline 52 & 29 & 120.5 & 116.5 & 4.0 \\
\hline 54 & 32 & 118.2 & 122.3 & -4.1 \\
\hline 57 & 27 & 122.6 & 116.4 & 6.2 \\
\hline 61 & 25 & 124.9 & ${ }^{a} 126.9$ & -2.0 \\
\hline 63 & 10 & 135.6 & ${ }^{\mathrm{a}} 138.4$ & -2.8 \\
\hline 63 & 37 & 146.6 & ${ }^{\mathrm{a}} 143.8$ & 2.8 \\
\hline 66 & 32 & 102.4 & 109.0 & -6.6 \\
\hline 67 & 27 & 110.7 & ${ }^{\mathrm{a}} 113.6$ & -2.9 \\
\hline 68 & 30 & 108.0 & 107.5 & .5 \\
\hline 71 & 11 & 116.8 & ${ }^{\mathrm{a}} 112.9$ & 3.9 \\
\hline 81 & 20 & 82.7 & ${ }^{\mathrm{a}} 89.3$ & -6.6 \\
\hline 83 & 25 & 98.9 & 100.9 & -2.0 \\
\hline 83 & 38 & 114.0 & 110.8 & 3.2 \\
\hline
\end{tabular}

${ }^{a}$ Water-table altitude interpolated from values in the observation-well cell and an adjacent cell for wells not at the center of a model cell. 

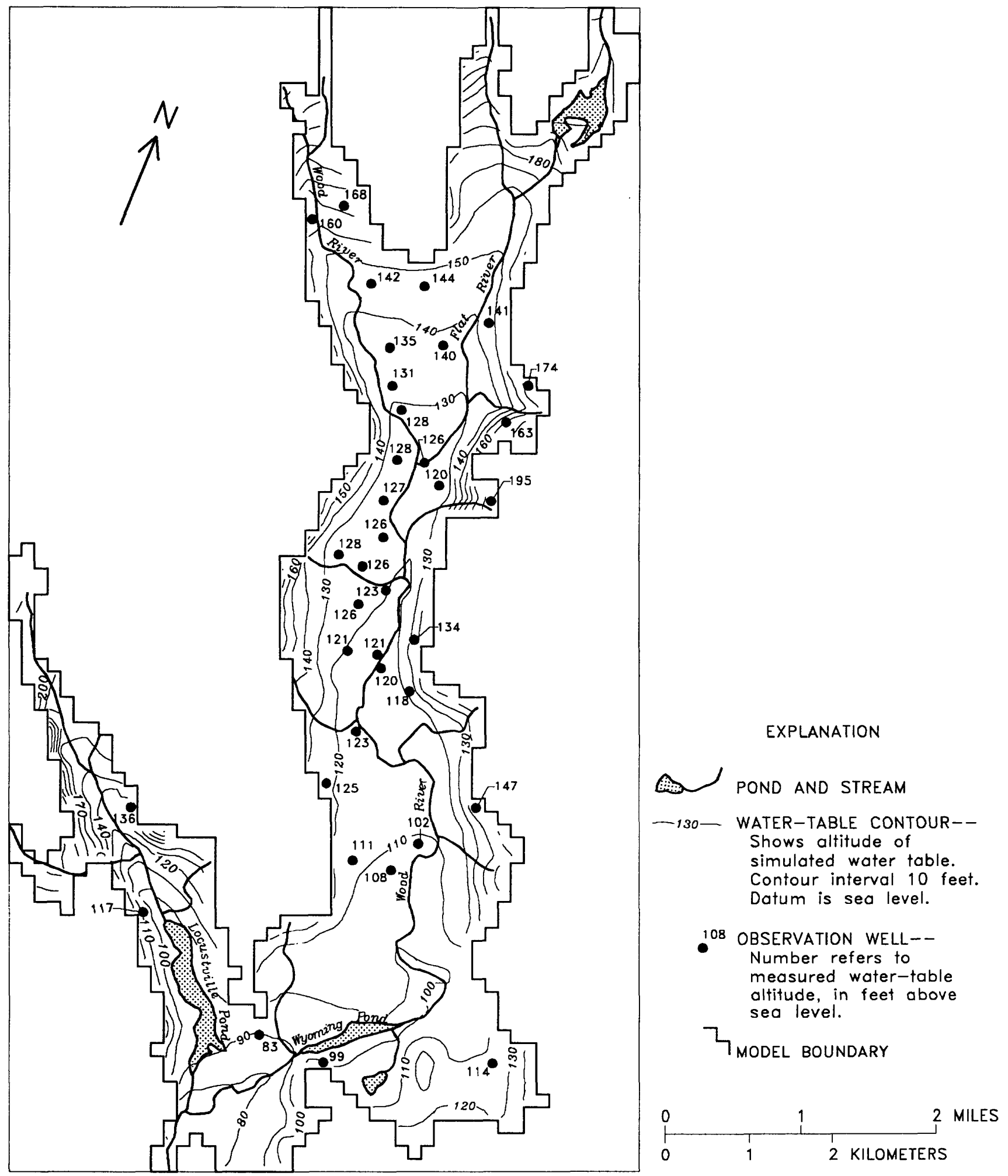

Figure 23.--Water-table altitude measured in observation wells, December 1982 and simulated steady-state water-table contours for nonpumping, long-term, average annual conditions, upper Wood River study area, 1942-89. 
Table 10.--Simulated steady-state water budget for the ground-water model, nonpumping conditions

\begin{tabular}{lclc}
\multicolumn{1}{c}{$\begin{array}{c}\text { Inflow rate } \\
\text { (cubic feet per second) }\end{array}$} & \multicolumn{1}{c}{$\begin{array}{c}\text { Outflow rate } \\
\text { (cubic feet per second) }\end{array}$} \\
\hline $\begin{array}{l}\text { Recharge } \\
\begin{array}{l}\text { Ground-water inflow from } \\
\text { till/bedrock uplands }\end{array}\end{array}$ & 20.4 & Ground-water runoff & 36.4 \\
$\begin{array}{l}\text { Stream infiltration } \\
\text { Total inflow }\end{array}$ & 17.5 & $\begin{array}{c}\text { Evaporation and } \\
\text { transpiration }\end{array}$ & 3.2 \\
\hline
\end{tabular}

Principal input parameters (table 11) were independently increased or decreased by a constant factor throughout the model area while other parameters were left unchanged. Differences (residuals) between calculated and measured steady-state watertable altitudes and streamflow for nonpumping conditions were used to evaluate model sensitivity.

After each sensitivity-test model simulation, the difference between the water-table altitude calculated at each cell representing an observation well and the water-table altitude measured at the observation well in December 1982 (table 9) was evaluated. Effects of changing each principal input parameter, except $\mathrm{Ka} \times 2$, are shown by the distribution of watertable residuals in figure 24 . A brief discussion of the effects of each parameter on water-table altitude and streamflow follows.

1. Horizontal hydraulic conductivity of the aquifer multiplied by $2(\mathrm{Ka} \times 2)$--Calculated water-table altitudes are sensitive to increases in horizontal hydraulic conductivity near till/stratified drift boundaries. Doubling $\mathrm{Ka}$ (not shown in fig. 24) caused the aquifer to drain too rapidly near till boundaries where the saturated thickness of the stratified-drift aquifer is small. The model failed because too many cells became dry.

2. Horizontal hydraulic conductivity of the aquifer divided by $2(\mathrm{Ka} / 2)--$ Model results are sensitive to lowering the horizontal hydraulic conductivity. Decreasing the Ka resulted in calculated watertable altitudes higher than the measured watertable altitudes because water cannot flow through aquifer material as easily as in the calibrated model (CM); thus, the water table rises. The median value of water-table residuals is $-2.3 \mathrm{ft}$.
Streamflow gain between gages was almost the same as in the CM.

3. Vertical hydraulic conductivity of the streambed multiplied by $10(\mathrm{Ks} \times 10)$--Increasing the vertical hydraulic conductivity of the streambed by an order of magnitude had little to no effect on calculated water-table altitudes (median value of water-table residuals was $\mathbf{- 0 . 1} \mathrm{ft}$ ) because hydraulic conductivity of the aquifer, not vertical hydraulic conductivity of the streambed, controlled vertical flow in the hydrologic system. Streamflow gain between gaging stations showed no change when compared to the CM.

4. Vertical hydraulic conductivity of the streambed divided by $10(\mathrm{Ks} / 10)$--Decreasing the vertical hydraulic conductivity of the streambed by an order of magnitude resulted in higher calculated water-table altitudes throughout the aquifer (the median value of water-table residuals was $-4.4 \mathrm{ft}$ ). The water could not drain as rapidly from the aquifer to the stream as in the CM; thus, the water table rises. Streamflow gain between gaging stations was the same as in the CM. Lowering the vertical hydraulic conductivity of the streambed by a factor of 10 produced much larger changes in water-table altitude in the aquifer, because vertical hydraulic conductivity of the streambed, not hydraulic conductivity of the aquifer, controlled vertical flow in the hydrologic system.

5. Streamflow multiplied by $2(\mathrm{Sf} \times 2)$--Increasing streamflow at the first cell of each of the 19 stream segments resulted in calculated water-table altitudes that were slightly higher than measured water-table altitudes (median value of water-table residuals was $-0.4 \mathrm{ft}$ ) because streamflow did not control ground-water flow in the hydrologic sys- 
Table 11.--Principal input parameters changed during sensitivity analysis for the steady-state simulation

Sensitivity test

Name of simulation

Calibrated model

Final nonpumping steady-state model

$\mathrm{CM}$

Horizontal hydraulic conductivity of the aquifer

1. Multiplied by 2

$\mathrm{Ka} \times 2$

2. Divided by 2

$\mathrm{Ka} / 2$

Vertical hydraulic conductivity of the streambed

3. Multiplied by 10

4. Divided by 10

$\mathrm{Ks} \times 10$

$\mathrm{Ks} / 10$

\section{Streamflow}

5. Multiplied by 2

Sf $\times 2$

6. Divided by 2

$\mathrm{Sf} / 2$

\section{Recharge}

$\begin{array}{ll}\text { 7. Multiplied by } 2 & \mathrm{R} \times 2\end{array}$

$\begin{array}{ll}\text { 8. Divided by } 1.3 & R / 1.3\end{array}$

tem. Streamflow gain between gaging stations increased by 78 percent when compared to the CM.

6. Streamflow divided by $2(\mathrm{Sf} / 2)$--Decreasing the streamflow at the first cell of each of the 19 stream segments resulted in calculated water-table altitudes that were slightly higher than measured water-table altitudes (median value of water-table residuals was $-0.4 \mathrm{ft}$ ) because streamflow did not control ground-water flow in the hydrologic system. Streamflow gain between gaging stations decreased by 41 percent when compared to the CM.

7. Recharge multiplied by $2(\mathrm{R} \times 2)$--Increasing the recharge rate from precipitation resulted in higher calculated water-table altitudes; the median value of water-table residuals was $-2.2 \mathrm{ft}$ because increased recharge to the aquifer caused a significant rise in the water table. Streamflow gain between gaging stations increased by 16 percent when compared to the CM.

8. Recharge divided by $1.3(\mathrm{R} / 1.3)$--Decreasing the recharge rate from precipitation by a factor of 1.3 had little to no effect on calculated water-table altitudes (median value of water-table residuals was $-0.2 \mathrm{ft}$ ) because the reduction in recharge was too small to significantly lower the water table. Streamflow gain between gaging stations decreased by 4 percent when compared to the CM. Decreasing recharge by a factor of more than 1.3 caused cells near till boundaries (where the aquifer is thin) to become dry; the model failed to converge.

In summary, results of the sensitivity analyses indicate that water-table altitudes are significantly affected by large increases and decreases in the horizontal hydraulic conductivity of the aquifer, large decreases in vertical hydraulic conductivity of the streambed, and large increases in precipitation recharge rate. Changing other model in put parameters had little or no effect on water-table altitudes. The analyses also have shown that streamflow gain between gaging stations is most sensitive to large increases in precipitation recharge and to increases or decreases in streamflow. Differences between calibrated steady-state model values and the 

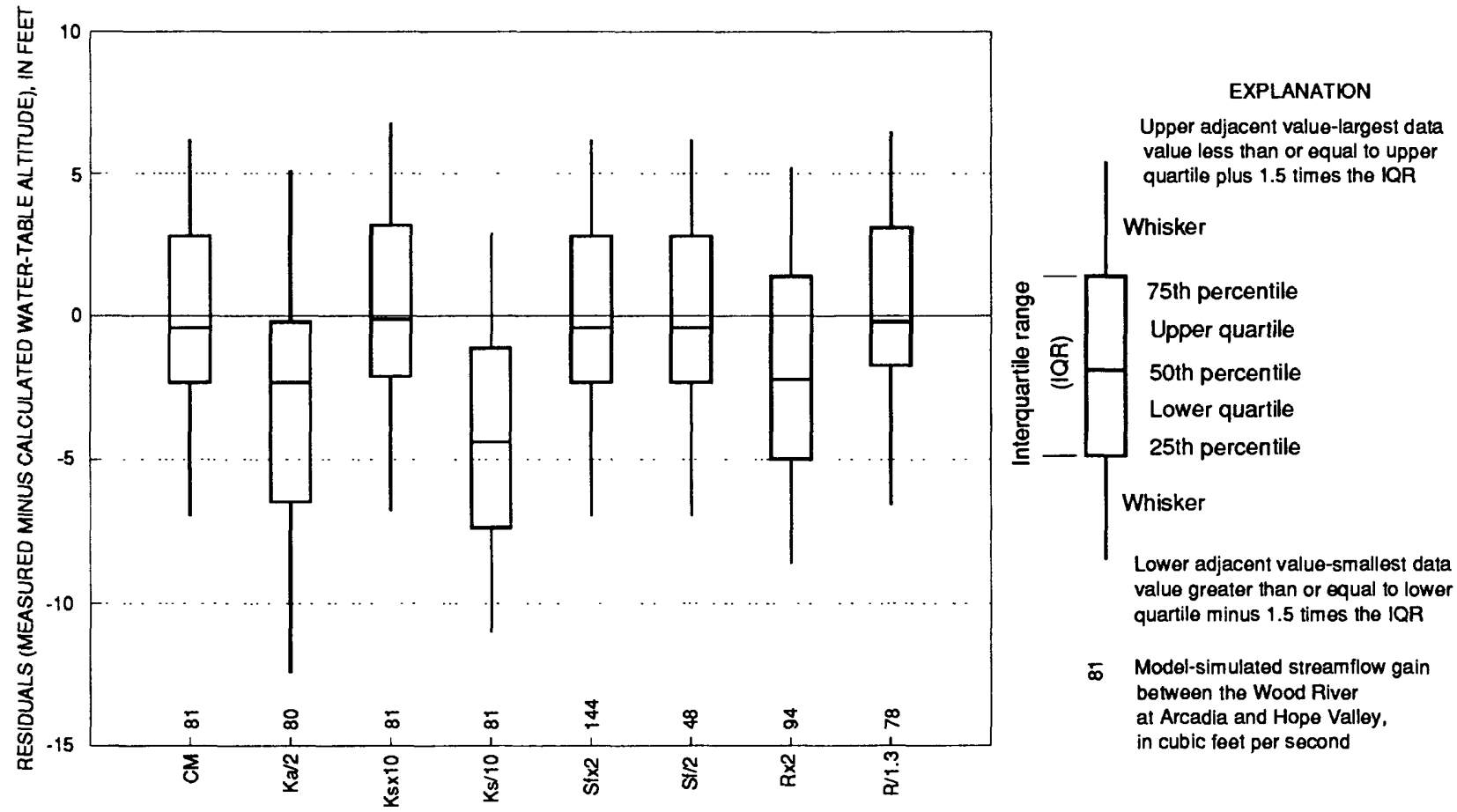

Figure 24.--Statistical distribution of the difference between measured and calculated water-table altitudes for sensitivity tests of the steady-state model (CM, calibrated model; Ka, aquifer horizontal hydraulic conductivity; Ks, streambed vertical hydraulic conductivity; Sf, streamflow; R, recharge).

values input for the sensitivity analysis illustrate the range in simulated response associated with what is believed to be the maximum uncertainty in each parameter.

\section{Simulated Effects of Ground-Water Development}

Ground-water withdrawals from the groundwater-flow system in the upper Wood River study area were simulated for both average and drought conditions. The objective of pumping simulations was to test the maximum pumping capacity of 11 well sites in the upper Wood River ground-water reservoir without (1) causing water-level declines of more than 25 percent of the unstressed saturated thickness or (2) causing flow to cease in any reach of the stream. All hypothetical wells were located at sites where 8-in. test wells were drilled and tested as part of this study.

For modeling purposes, all pumpage was assumed to be exported from the model area. If pumpage is returned to the flow system upstream from withdrawal points, however, water table and streamflow declines will be less than those predicted by the model. Therefore, simulation results shown here are conservative; higher tot al pumpage would be possible under return-flow conditions.

\section{Hypothetical Ground-Water Withdrawals During Average Conditions}

Five development alternatives were simulated with the steady-state ground-water model by use of 11 hypothetical wells in the upper Wood River ground-water reservoir. The estimated maximum pumping rate for each individual well at the 11 fieldtested sites is shown in table 12. These estimates are based on the specific capacity of the well and the amount of water available above the top of the well screen. Each well was assumed to have an interior diameter of 18 in. and a 3 -in. gravel pack, which results in a total diameter of 24 in. (such a well is called an 18 - by 24 -inch gravel-packed well). Estimates of the maximum pumping rate from wells ranged from 1 to $2 \mathrm{Mgal} / \mathrm{d}$. The estimated maximum 
Table 12.--Selected ground-water-development alternatives tested for steady-state conditions

[ft, feet; in., inches; Mgal/d, million gallons per day; -.., not pumped]

\begin{tabular}{|c|c|c|c|c|c|c|c|c|c|c|c|c|c|c|c|c|}
\hline \multirow{4}{*}{$\begin{array}{c}\text { Well } \\
\text { number }\end{array}$} & \multicolumn{4}{|c|}{ Data from large-diameter test well } & \multirow{4}{*}{$\begin{array}{l}\text { Water } \\
\text { level } \\
\text { above } \\
\text { screen } \\
(\mathrm{ft})\end{array}$} & \multirow{4}{*}{$\begin{array}{c}\text { Estimated } \\
\text { maximum } \\
\text { pumping } \\
\text { rate }_{1} \\
(\mathrm{Mgal} / \mathrm{d})\end{array}$} & \multicolumn{10}{|c|}{ Pumping periods simulated ${ }^{2}$} \\
\hline & \multirow{3}{*}{$\begin{array}{l}\text { Model } \\
\text { cell } \\
\text { row, } \\
\text { column }\end{array}$} & \multirow{3}{*}{$\begin{array}{c}\text { Screened } \\
\text { interval } \\
\text { (ft) }\end{array}$} & \multirow{3}{*}{$\begin{array}{l}\text { Screen } \\
\text { slot size } \\
\text { (in.) }\end{array}$} & \multirow{3}{*}{$\begin{array}{l}\text { Pumping } \\
\text { rate }\end{array}$} & & & \multicolumn{5}{|c|}{$\begin{array}{l}\text { Average } \\
\text { condition }\end{array}$} & \multicolumn{5}{|c|}{$\begin{array}{l}\text { Drought } \\
\text { condition }\end{array}$} \\
\hline & & & & & & & \multicolumn{10}{|c|}{ Development alternative (pumpage, in Mgal/d) } \\
\hline & & & & & & & 1 & 2 & 3 & 4 & 5 & 6 & 7 & 8 & 9 & 10 \\
\hline EXW 520 & 32,31 & $\begin{array}{l}59-64 \\
64-74\end{array}$ & $\begin{array}{l}.080 \\
.100\end{array}$ & .8 & 47 & 2.0 & 1.0 & --- & $--\cdot$ & 1.0 & 1.0 & 1.0 & --- & -- & 1.0 & 1.0 \\
\hline EXW 515 & 36,33 & $\begin{array}{l}78-83 \\
83-93\end{array}$ & $\begin{array}{l}.040 \\
.060\end{array}$ & .7 & 72 & 2.0 & 1.0 & --- & $\cdots$ & 1.0 & 1.0 & 1.0 & $-\cdots$ & -.. & 1.0 & 1.0 \\
\hline EXW 552 & 42,30 & $\begin{array}{l}70-75 \\
75-85\end{array}$ & $\begin{array}{l}.200 \\
.100\end{array}$ & 1.0 & 66 & 2.0 & 1.0 & 1.0 & 1.0 & 1.0 & 1.0 & 1.0 & 1.0 & 1.0 & 1.0 & 1.0 \\
\hline EXW 481 & 47,29 & $\begin{array}{l}85-90 \\
90-100\end{array}$ & $\begin{array}{l}.040 \\
.080\end{array}$ & .8 & 79 & 2.0 & 1.0 & 1.0 & 1.0 & 1.0 & 1.5 & 1.0 & 1.0 & 1.0 & 1.0 & 1.5 \\
\hline EXW 547 & 52,28 & $\begin{array}{l}88-93 \\
93-98 \\
98-103\end{array}$ & $\begin{array}{l}.060 \\
.040 \\
.100\end{array}$ & .9 & 83 & 2.0 & -.. & 1.0 & 1.0 & 1.0 & 1.0 & $-\cdot$ & 1.0 & 1.0 & 1.0 & 1.0 \\
\hline RIW 696 & 87,17 & $\begin{array}{l}48-53 \\
53-58 \\
58-63 \\
82-87\end{array}$ & $\begin{array}{l}.080 \\
.030 \\
.040 \\
.040\end{array}$ & .4 & 40 & 1.0 & $\cdots$ & ... & -.. & -.. & 1.0 & $\cdots$ & -.. & ... & -.. & 1.0 \\
\hline Total & & & & & & & $\overline{6.0}$ & 6.0 & 8.0 & 10.0 & 12.0 & 6.0 & 6.0 & 8.0 & 10.0 & 12.0 \\
\hline
\end{tabular}

${ }^{1}$ Estimated maximum pumping rates are not additive because interference between wells was not considered. Estimates are based on specific capacity projected from drawdown at 1 -foot radius and water available above the top of the well screen. Optimum well size required to pump estimated maximum is an 18- by 24-inch gravel-packed well.

${ }^{2}$ Wells were pumped continuously during all simulations.

${ }^{3}$ Recharge and streamflow reduced 25 percent to simulate drought condition. 
pumping rates are not additive because interference between pumped wells was not considered. Estimated maximum pumping rates were not simulated in the model, but they do provide some measure of potential short-term emergency well yields.

Table 12 summarizes pumping simulations for development alternatives under long-term average annual and drought (discussed later in this report) conditions. Total pumpage for selected development alternatives ranged from 6 to $12 \mathrm{Mgal} / \mathrm{d}$. Individual wells were pumped at constant rates of $1 \mathrm{Mgal} / \mathrm{d}$ for all simulations except development alternatives 5 and 10 , in which 2 of the 11 wells were pumped at constant rates of $1.5 \mathrm{Mgal} / \mathrm{d}$.

During the evaluation of the upper Wood River ground-water reservoir's potential long-term yield, wells were pumped simultaneously during all development alternatives. The number of wells pumped concurrently during development alternatives ranged from 6 to 11 wells. The 10 ground-water pumpage scenarios shown in table 12 are not the only development alternatives possible; other combinations of wells and pumping rates may produce similar total yields.

\section{Development alternatives 1 and 2}

Development alternatives 1 and 2 (table 12) tested the ability of the upper Wood River groundwater reservoir to sustain an average daily yield of 6 $\mathrm{Mgal} / \mathrm{d}$. Development alternative 1 tests the northern part and development alternative 2 tests the southern part of the ground-water reservoir. During both simulations, six wells were pumped at constant rates of $1 \mathrm{Mgal} / \mathrm{d}$.

Locations of wells and contours of the position of the steady-state water table are shown in figure 25 for development alternative 1 and in figure 26 for development alternative 2. Total pumpage of 6 $\mathrm{Mgal} / \mathrm{d}$ produced drawdowns at pumped-well cells that ranged from $3.0 \mathrm{ft}$ at well EXW 515 (cell 36,33) to $9.5 \mathrm{ft}$ at well EXW 510 (cell 39,34) in the northern part of the ground-water reservoir. Drawdown given at a pumped-well node is the average drawdown over the entire area of the cell. Drawdown at the pumped well would be greater than that shown for the pumped-well cell. Cell drawdown would be adjusted on the basis of the desired well radius (Trescott and others, 1976, p. 10) to estimate the amount of additional drawdown at the pumped well. In the southern part of the ground-water reservoir, total pumpage of $6 \mathrm{Mgal} / \mathrm{d}$ produced drawdowns at pumped-well cells that ranged from $1.6 \mathrm{ft}$ at well RIW 712 (cell 70, 32) to $6.0 \mathrm{ft}$ at well HOW 477 (cell 56, 27).

The areal extent of drawdowns greater than or equal to $0.5 \mathrm{ft}$ for development alternatives 1 and 2 is shown in figures 27 and 28 . Water levels in small kettle-hole ponds that are within the areas influenced by pumping will decline by the same amount as groundwater levels.

No stream reaches became dry during development alternatives 1 and 2 . Total stream gain in the model was reduced from $33.2 \mathrm{ft}^{3} / \mathrm{s}$ under nonpumping conditions to $23.4 \mathrm{ft}^{3} / \mathrm{s}$ during development alternative 1 and to $24.0 \mathrm{ft}^{3} / \mathrm{s}$ during development alternative 2.

Results of simulation of development alternatives 1 and 2 indicate that the upper Wood River ground-water reservoir can sustain an average daily yield of $6 \mathrm{Mgal} / \mathrm{d}$ from either the northern or southern part of the basin under long-term average annual conditions. Criteria for streamflow depletion and reduction in saturated thickness of the aquifer for hypothetical simulations were met with both development alternatives. No stream reaches became dry, and reduction in the saturated thickness of the aquifer was less than 25 percent. The six pumped wells used in each of these simulations are two of several combinations of wells (shown in table 12) that would produce a sustained yield of $6 \mathrm{Mgal} / \mathrm{d}$.

\section{Development alternatives 3 and 4}

Results of simulation of development alternatives 3 and 4 (table 12), in which the model was used to test increased pumpage, show that the upper Wood River ground-water reservoir is capable of sustaining an average daily yield of 8 or $10 \mathrm{Mgal} / \mathrm{d}$ respectively, under long-term average annual conditions. Total pumpage of $8 \mathrm{Mgal} / \mathrm{d}$ produced drawdowns at pumped-well cells that ranged from $1.6 \mathrm{ft}$ at well RIW 712 to $9.4 \mathrm{ft}$ at well EXW 510. Total pumpage of $10 \mathrm{Mgal} / \mathrm{d}$ produced drawdowns at pumped-well cells that ranged from $1.6 \mathrm{ft}$ at well RIW 712 to $9.5 \mathrm{ft}$ at well EXW 510. Total stream gain in the model was reduced from $33.2 \mathrm{ft}^{3} / \mathrm{s}$ under nonpumping conditions to $21.0 \mathrm{ft}^{3} / \mathrm{s}$ during development alternative 3 and to $18.0 \mathrm{ft}^{3} / \mathrm{s}$ during development alternative 4. No stream reaches became dry, and reduction in the saturated thickness of the aquifer was less than 25 percent. Results of simulation of development alternatives 3 and 4 demonstrate that the upper Wood River ground-water reservoir can sustain an average-daily yield of $10 \mathrm{Mgal} / \mathrm{d}$ by using 

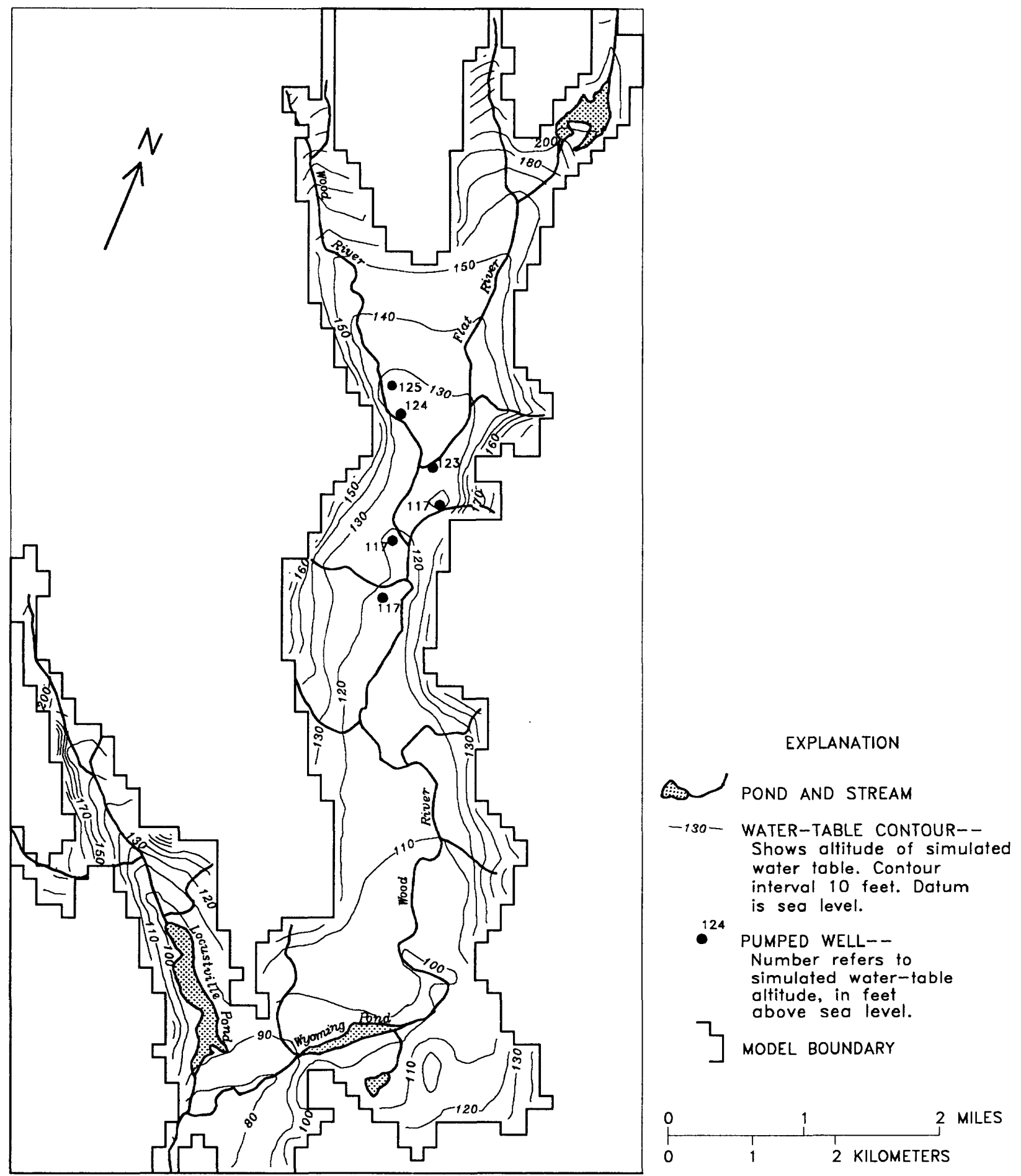

Figure 25.--Simulated steady-state water-table contours for long-term average annual conditions, development alternative 1, pumping 6 million gallons per day from the northern part of the upper Wood River study area. 

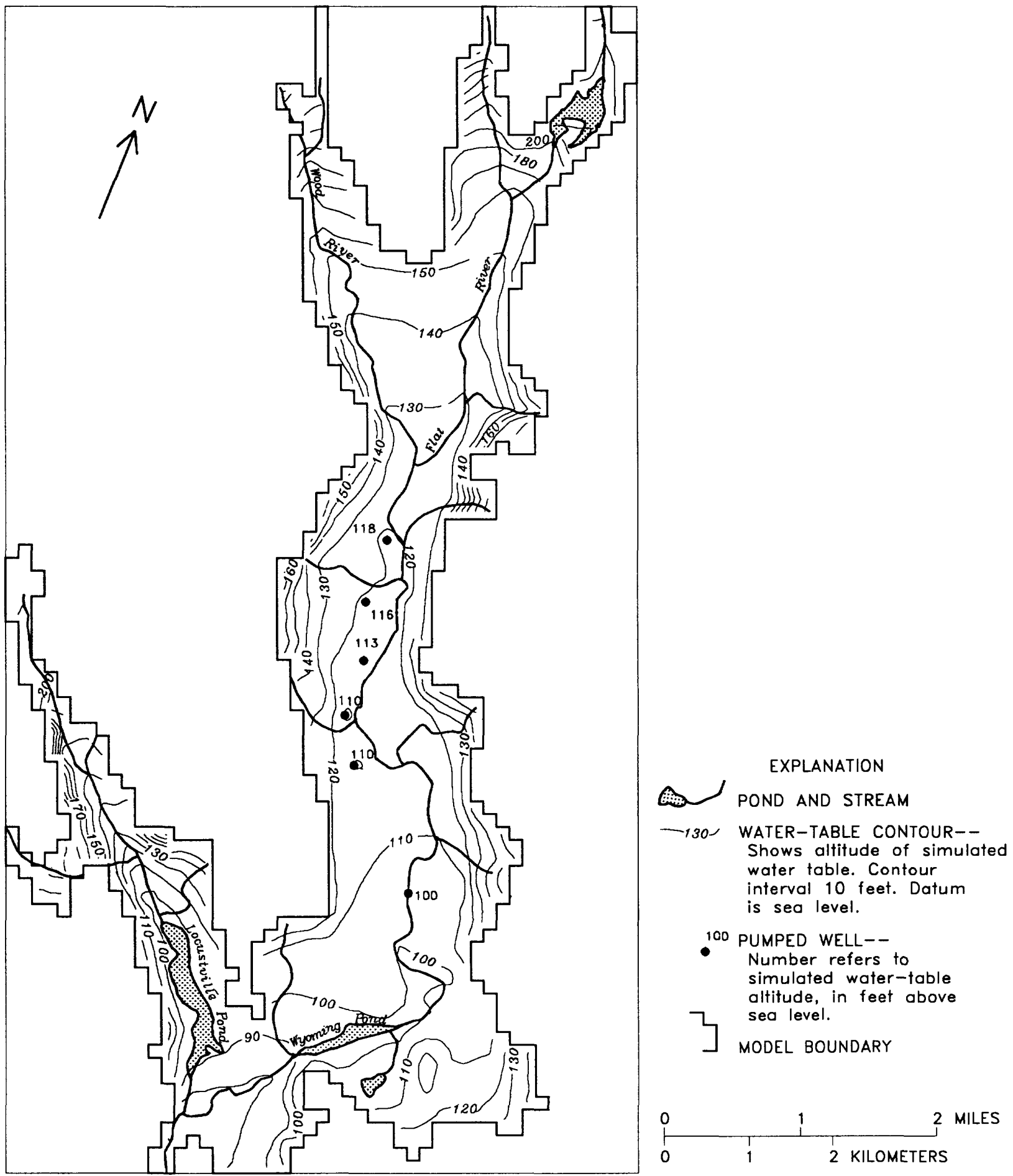

Figure 26.--Simulated steady-state water-table contours for long-term average annual conditions, development alternative 2, pumping 6 million gallons per day from the southern part of the upper Wood River study area. 

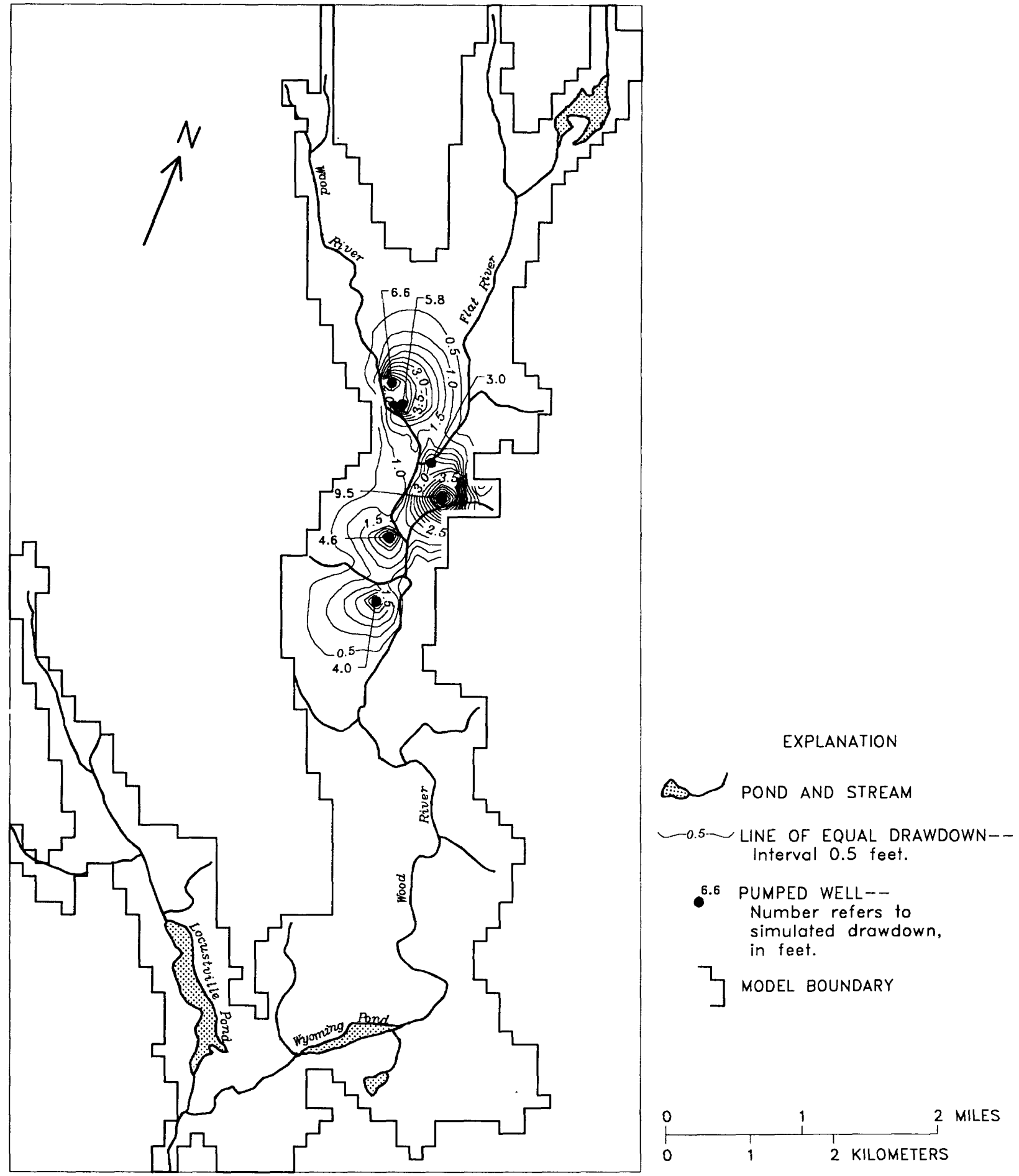

Figure 27.--Simulated steady-state drawdown contours for long-term average annual conditions, development alternative 1, pumping 6 million gallons per day from the northern part of the upper Wood River study area. 

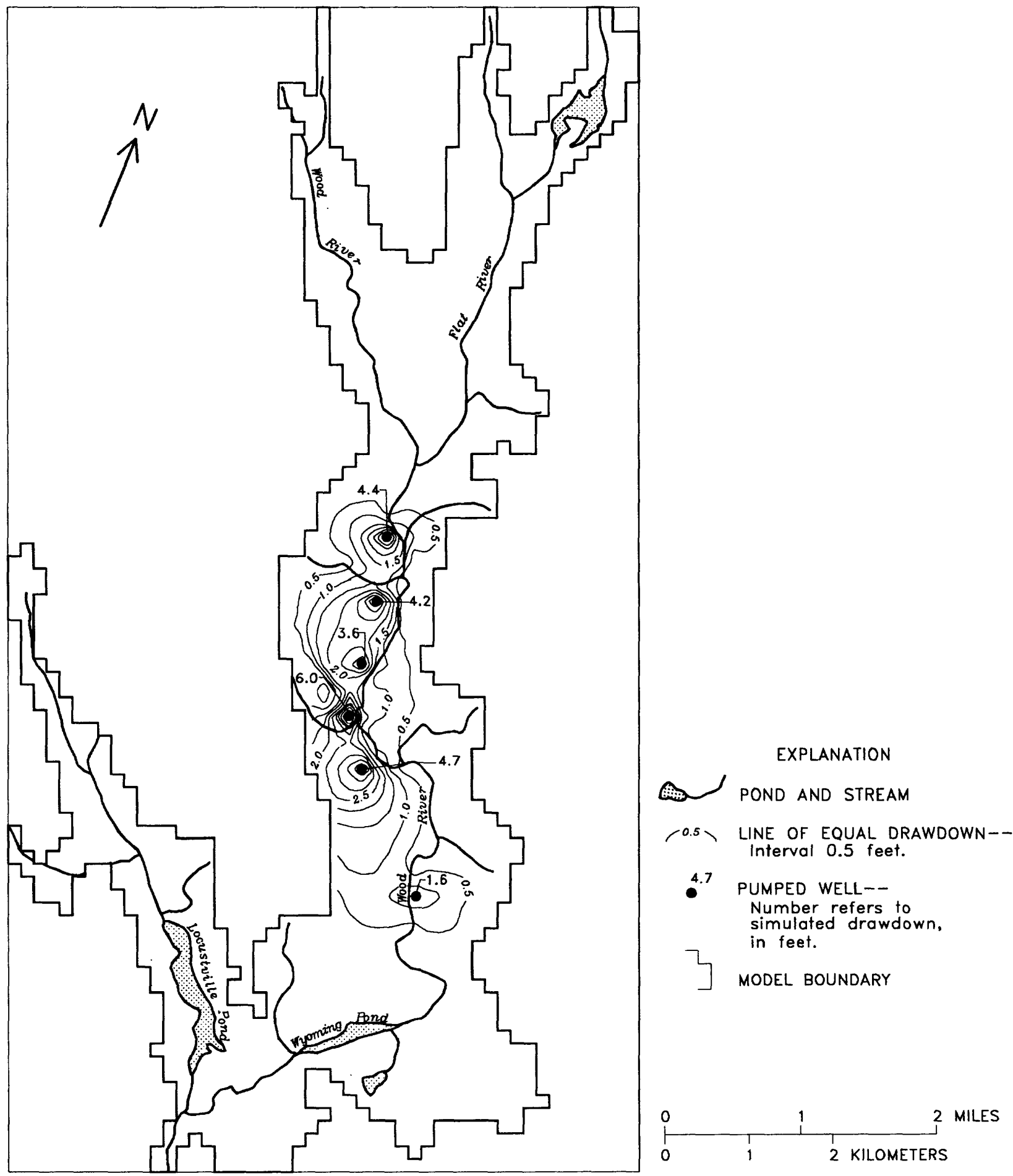

Figure 28.--Simulated steady-state drawdown contours for long-term average annual conditions, development alternative 2, pumping 6 million gallons per day from the southern part of the upper Wood River study area. 
different combinations of wells under long-term average annual conditions.

\section{Development alternative 5}

Ground-water withdrawals were gradually increased to test the maximum pumping capacity of $\mathbf{1 1}$ well sites in the upper Wood River ground-water reservoir under long-term average annual conditions. Pumped wells were added, one at a time, and then pumping rates were gradually increased until cells along the edge of the model became dry and the model failed. Simulations show that the upper Wood River ground-water reservoir can sustain a maximum yield of $12 \mathrm{Mgal} / \mathrm{d}$ from 11 wells (development alternative 5) at sites tested in the field.

During development alternative 5, nine wells were pumped at a constant rate of $1 \mathrm{Mgal} / \mathrm{d}$, and two wells were pumped at a constant rate of $1.5 \mathrm{Mgal} / \mathrm{d}$. Well locations and contours of the steady-statepumping water table for development-alternative 5 are shown in figure 29. Total pumpage of $12 \mathrm{Mgal} / \mathrm{d}$ produced drawdowns at pumped-well cells that ranged from $2.4 \mathrm{ft}$ at well RIW 712 to $9.5 \mathrm{ft}$ at well EXW 510. The areal extent of drawdowns greater than or equal to $0.5 \mathrm{ft}$ for development alternative 5 is shown in figure 30 .

Table 13 allows comparison between pumping rates and drawdowns for aquifer tests done as part of this study and pumping rates and drawdowns simulated under steady-state-pumping conditions. Table 13 also allows comparison between measured drawdown from aquifer tests and model drawdown for pumping of $12 \mathrm{Mgal} / \mathrm{d}$ at cells near aquifer-test sites. Model drawdowns are listed for each pumped cell. Also listed are pumped-cell drawdowns adjusted to a 1-ft well radius by extrapolation with the Thiem equation (Trescott and others, 1976, p. 10). For example, pumped-cell drawdown of $6.6 \mathrm{ft}$ at well EXW 525, adjusted for a well with a 1-ft radius, becomes $9.6 \mathrm{ft}$. Drawdowns were adjusted to a 1-ft well radius because this is the radius of a typical gravel-packed well installed in Rhode Island.

In the stratified-drift aquifer, maximum cell drawdown did not exceed 16 percent of the initial saturated thickness of the aquifer at any cell during any pumping simulation. Maximum simulated drawdown for a well adjusted to a 1-ft radius during total pumpage of $12 \mathrm{Mgal} / \mathrm{d}$ in the upper Wood River area was $15.6 \mathrm{ft}$ (nodal drawdown was $9.5 \mathrm{ft}$ at cell 39,34; see table 13) of an available $61 \mathrm{ft}$ of saturated thickness.
No stream reaches became dry during development alternative 5. Total stream gain in the model was reduced from $33.2 \mathrm{ft}^{3} / \mathrm{s}$ under nonpumping conditions to $14.3 \mathrm{ft}^{3} / \mathrm{s}$ during development alternative 5 .

All criteria were met with development alternative 5. Total pumpage did not cause water-level declines that would lower the unstressed saturated thickness of the aquifer by more than 25 percent, and no stream reaches became dry under long-term average annual conditions. Sustained pumping of 12 $\mathrm{Mgal} / \mathrm{d}$ would reduce the flow of the Wood River at the Hope Valley station to $139 \mathrm{ft}^{3} / \mathrm{s}$, a reduction of $18.9 \mathrm{ft}^{3} / \mathrm{s}$. The $7 \mathrm{Q} 10$ flow at the station is $20.4 \mathrm{ft}^{3} / \mathrm{s}$. If all the wells are developed at this extreme low-flow condition and all the pumped water is exported from the basin, little flow would remain in the stream.

\section{Hypothetical Ground-Water Withdrawals During Drought Conditions}

The upper Wood River model was also used to test the ability of the ground-water reservoir to sustain an average daily yield of 6 to $12 \mathrm{Mgal} / \mathrm{d}$ under drought conditions. Drought conditions were simulated in the model by reducing long-term average annual recharge from precipitation, inflow from till-covered bedrock uplands, and streamflow by 25 percent. This reduction in percentage is the same as that used in the model of the lower Wood River ground-water reservoir (Dickerman and others, 1990) and approximates the 1963-66 drought, a period considered representative of extreme drought conditions. The 1963-66 drought period represents the lowest 4 consecutive annual precipitation values recorded at the National Weather Service Station at Kingston since the station began operation in 1889 .

Simulated steady-state water-table contours for nonpumping drought conditions are shown in figure 31 to indicate the differences between water-table altitude during drought conditions and water-table altitude for long-term average annual conditions (fig. 23). In general, most water-table altitudes are about $1 \mathrm{ft}$ lower under drought conditions. In some areas near the edge of the stratified-drift aquifer by the till boundary, however, the water-table altitude is about $5 \mathrm{ft}$ lower under drought conditions than under longterm average annual conditions.

\section{Development alternatives 6 and 7}

For development alternatives 6 and 7 (table 12), the same wells and pumping rates were selected for 

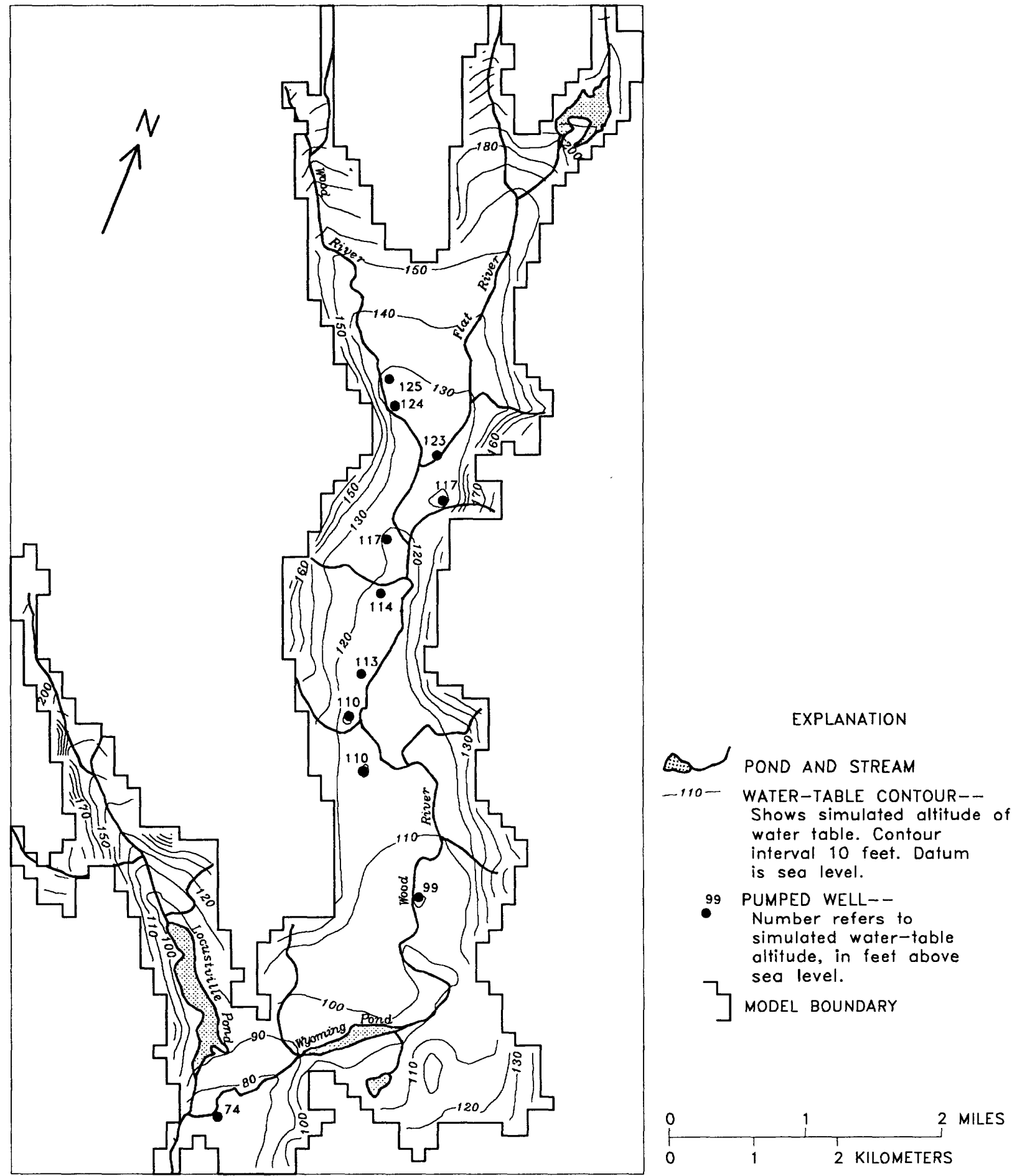

Figure 29.--Simulated steady-state water-table contours for long-term average annual conditions, development alternative 5, pumping 12 million gallons per day, upper Wood River study area. 

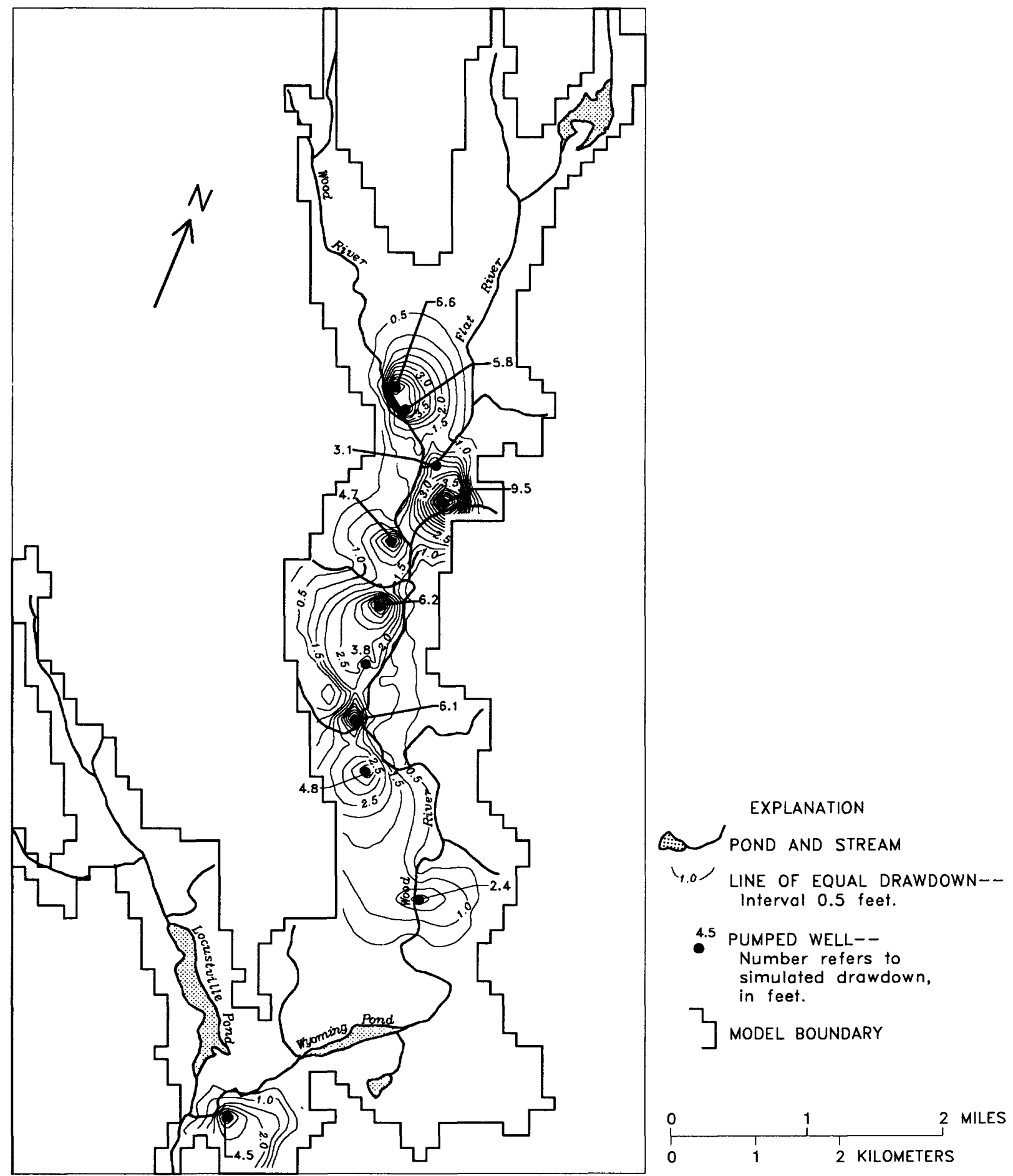

Figure 30.--Simulated steady-state drawdown contours for long-term average annual conditions, development alternative 5, pumping 12 million gallons per day, upper Wood River study area. 
Table 13.--Drawdowns from 2-day aquifer tests and simulated steady-state drawdowns during development alternative 5, with pumping 12 million gallons per day

[Mgal/d, million gallons per day; $\mathrm{ft}, \mathrm{feet}]$

\begin{tabular}{|c|c|c|c|c|c|c|c|}
\hline \multirow[b]{2}{*}{$\begin{array}{c}\text { Well } \\
\text { number }\end{array}$} & \multirow[b]{2}{*}{$\begin{array}{l}\text { Model } \\
\text { cell } \\
\text { row, } \\
\text { column }\end{array}$} & \multicolumn{2}{|c|}{ Aquifer test } & \multicolumn{4}{|c|}{ Model simulation } \\
\hline & & $\begin{array}{l}\text { Pumping } \\
\text { rate }^{1} \\
(\mathrm{Mgal} / \mathrm{d})\end{array}$ & $\begin{array}{c}\text { Drawdown }^{2} \\
\text { (ft) }\end{array}$ & $\begin{array}{l}\text { Pumping } \\
\text { rate } \\
\text { (Mgal/d) }\end{array}$ & $\begin{array}{c}\text { Drawdown } \\
\text { (ft) }\end{array}$ & $\begin{array}{c}\text { Drawdown at } \\
\text { pumped cell } \\
\text { (ft) }\end{array}$ & $\begin{array}{c}\text { Drawdown } \\
5 \\
(\mathrm{ft})\end{array}$ \\
\hline EXW 525 & 30,30 & 0.8 & $4.6(2.2)$ & 1.0 & $9.1(2.2)$ & 6.6 & 9.6 \\
\hline EXW 520 & 32,31 & .8 & $4.7(2.0)$ & 1.0 & $8.7(2.0)$ & 5.8 & 9.2 \\
\hline EXW 515 & 36,33 & .7 & 15.2 & 1.0 & $6.4(1.9)$ & 3.1 & 6.9 \\
\hline EXW 510 & 39,34 & .4 & $9.6(2.0)$ & 1.0 & $14.7(2.0)$ & 9.5 & 15.6 \\
\hline EXW 552 & 42,30 & 1.0 & $9.0(2.0)$ & 1.0 & $8.8(2.0)$ & 4.7 & 9.5 \\
\hline EXW 481 & 47,29 & .8 & $24.2(2.2)$ & 1.5 & $12.7(2.2)$ & 6.2 & 14.0 \\
\hline EXW 547 & 52,28 & .9 & $8.8(2.4)$ & 1.0 & $7.0(2.4)$ & 3.8 & 7.8 \\
\hline HOW 477 & 56,27 & 1.0 & $15.1(2.0)$ & 1.0 & $10.5(2.0)$ & 6.1 & 11.2 \\
\hline HOW 445 & 60,28 & .8 & $9.0(1.9)$ & 1.0 & $7.8(1.9)$ & 4.8 & 8.4 \\
\hline RIW 712 & 70,32 & .7 & $7.2(2.1)$ & 1.5 & $5.4(2.1)$ & 2.4 & 6.0 \\
\hline RIW 696 & 87,17 & .4 & $4.2(1.9)$ & 1.0 & $9.4(1.9)$ & 4.5 & 10.2 \\
\hline Total & & $\overline{\mathbf{8 . 4 0}}$ & & $\overline{12.0}$ & & & \\
\hline
\end{tabular}

${ }^{1}$ Wells not pumped simultaneously.

2 Numiber in parentheses is distance from pumped well to observation well, in feet.

3 W'ells pumped simultaneously.

- Drawdown at model pumped cell adjusted (Trescott and others, 1976, p. 10) to radius shown in parentheses.

5 Drawdown at model pumped cell adjusted to 1 -foot radius.

testing under drought conditions as were tested during development alternatives 1 and 2 for longterm average annual conditions. Locations of the six pumped wells and simulated contours of the position of the steady-state water table for development alternatives 6 and 7 are shown in figures 32 and 33. At a total pumpage of $6 \mathrm{Mgal} / \mathrm{d}$, drawdowns at pumpedwell cells ranged from $3.1 \mathrm{ft}$ (at well EXW 515) to 9.6 ft (at well EXW 510) in the northern part of the basin and from $1.6 \mathrm{ft}$ (at well RIW 712) to $6.1 \mathrm{ft}$ (at well HOW 477) in the southern part of the basin. Drawdowns greater than or equal to $0.5 \mathrm{ft}$ under simulated drought conditions cover about the same area as shown in figures 27 and 28 for pumping under longterm average annual conditions because pumping rates are identical for both conditions.

Results of simulation of development alternatives 6 and 7 show that the upper Wood River ground-water reservoir can sustain an average daily yield of $6 \mathrm{Mgal} / \mathrm{d}$ under drought conditions. During pumping simulations under drought conditions, streamflow induced from the stream to wells was 9 to 11 percent less than under long-term average annual conditions. Total stream gain in the model was reduced from $23.7 \mathrm{ft}^{3} / \mathrm{s}$ under nonpumping conditions to $15.1 \mathrm{ft}^{3} / \mathrm{s}$ during development alternative 6 and to 

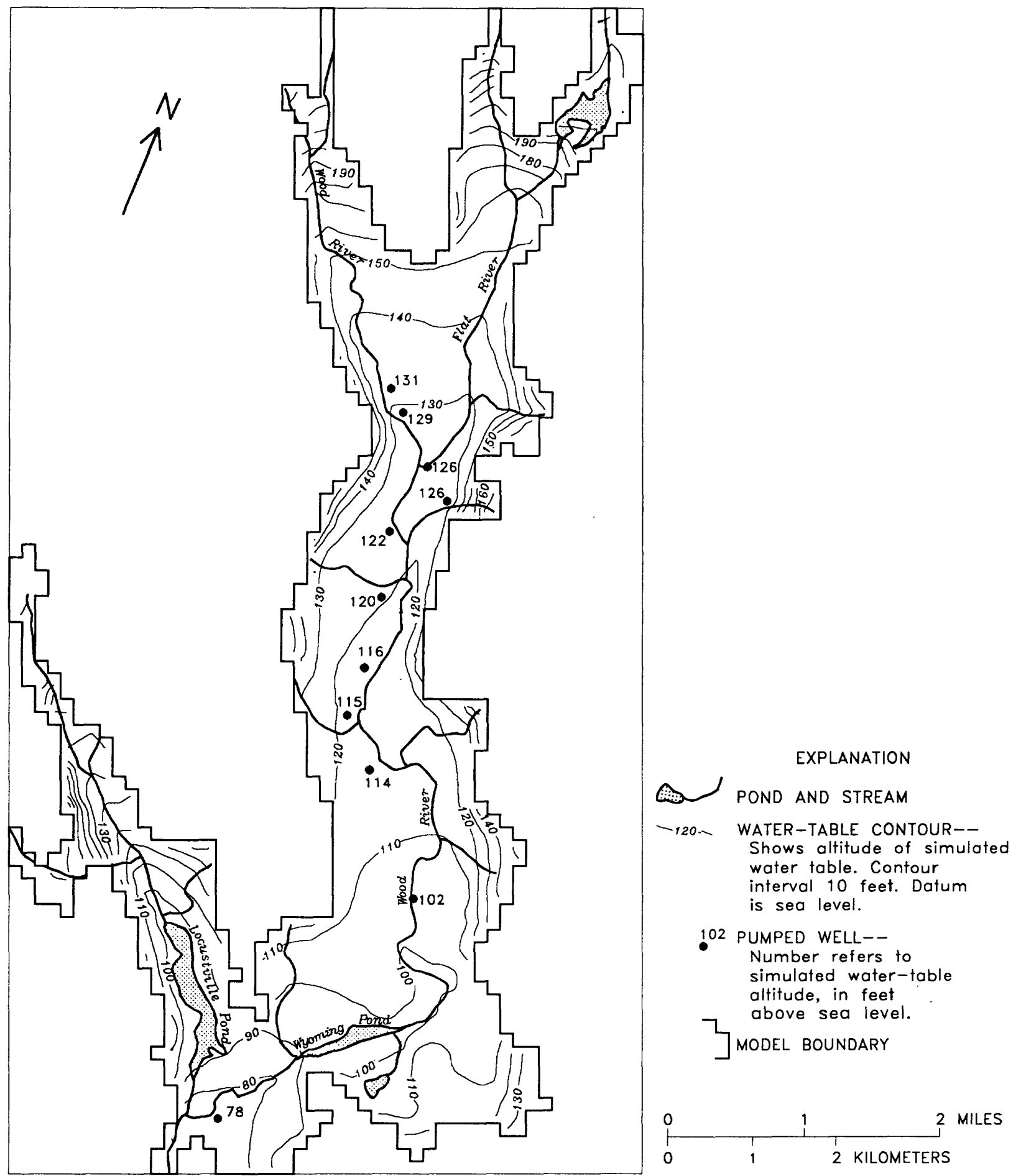

Figure 31.--Simulated steady-state water-table contours for drought conditions, nonpumping, upper Wood River study area. 

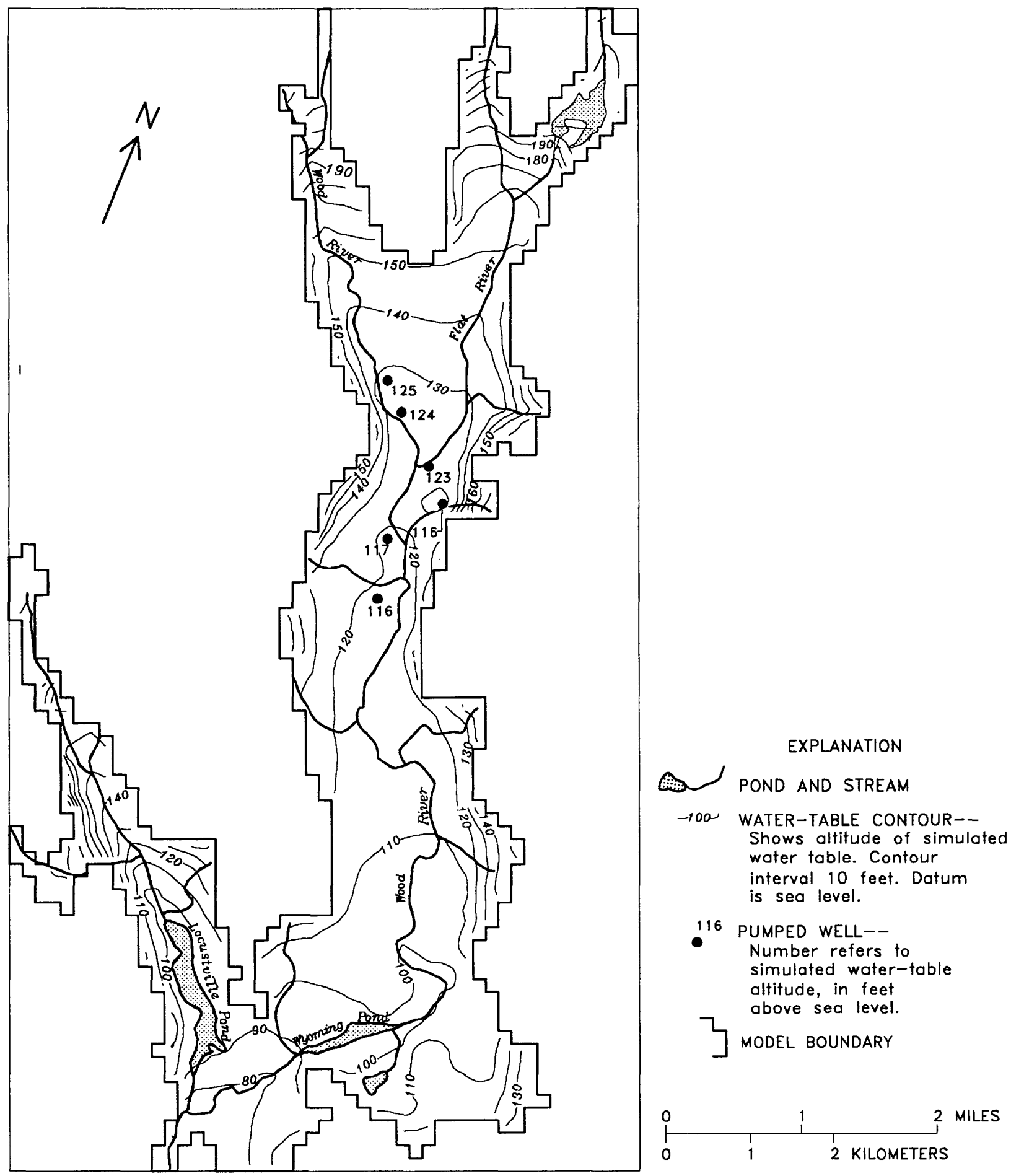

Figure 32.--Simulated steady-state water-table contours for drought conditions, development alternative 6, pumping 6 million gallons per day from the northern part of the upper Wood River study area. 

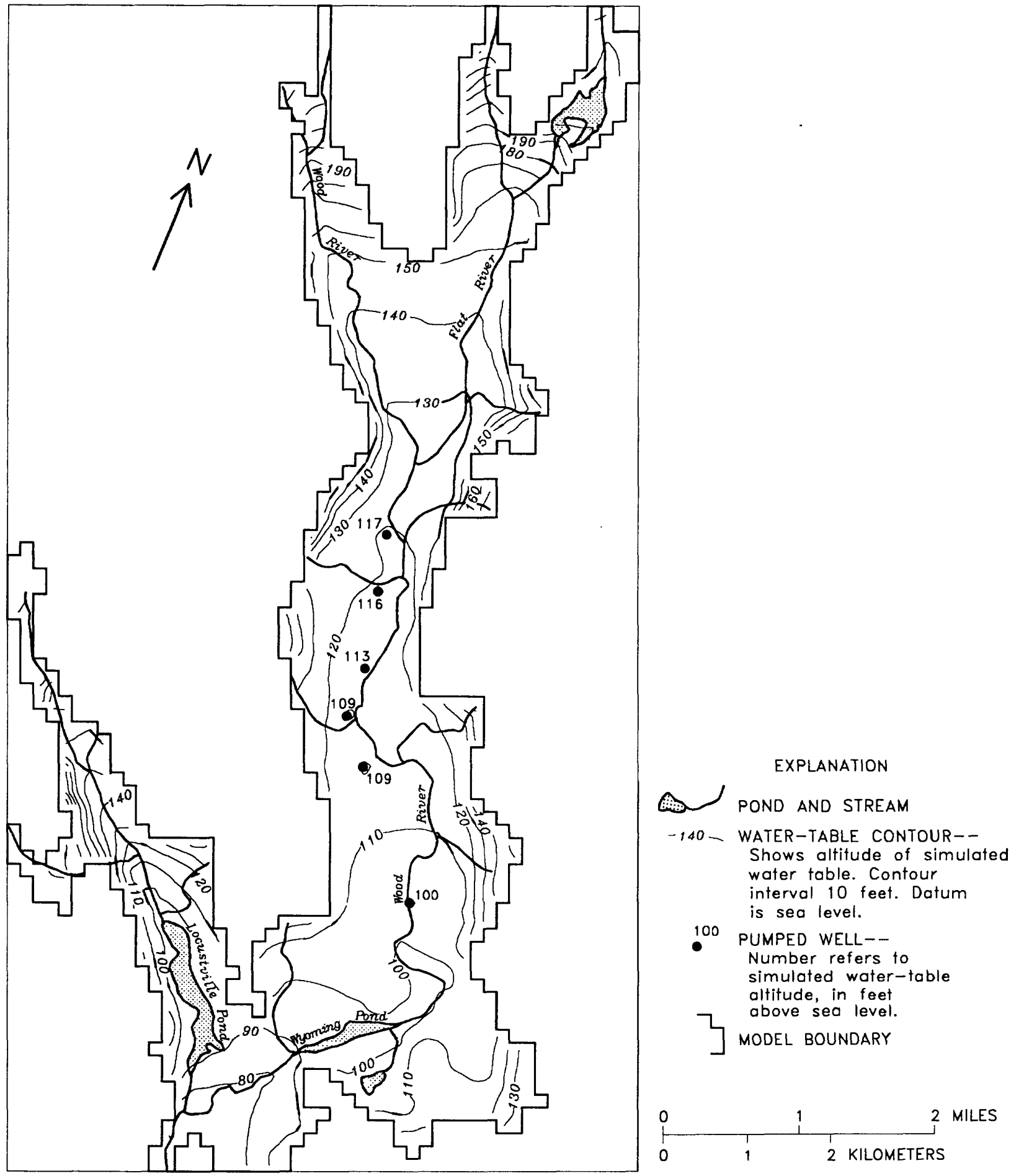

Figure 33.--Simulated steady-state water-table contours for drought conditions, development alternative 7, pumping 6 million gallons per day from the southern part of the upper Wood River study area. 
$15.3 \mathrm{ft}^{3} / \mathrm{s}$ during development alternative 7 . No stream reaches became dry, and reduction in saturated thickness was less than 25 percent.

\section{Development alternatives 8 and 9}

Results of simulation of development alternatives 8 and 9 (table 12) show that the upper Wood River ground-water reservoir is capable of sustaining an average daily yield of 8 or $10 \mathrm{Mgal} / \mathrm{d}$, respectively, under drought conditions. In alternative 8 , total pumpage of $8 \mathrm{Mgal} / \mathrm{d}$ resulted in drawdowns at pumped-well cells that ranged from $1.6 \mathrm{ft}$ (at well RIW 712) to $9.5 \mathrm{ft}$ (at well EXW 510). In alternative 9, total pumpage of $10 \mathrm{Mgal} / \mathrm{d}$ resulted in drawdowns at pumped-well cells that ranged from $1.6 \mathrm{ft}$ (at well RIW 712) to $9.6 \mathrm{ft}$ (at well EXW 510). Drawdowns were about the same when 8 and $10 \mathrm{Mgal} / \mathrm{d}$ were pumped under drought conditions as they were for the long-term average annual conditions because pumping rates are identical for both conditions. During pumping simulations under drought conditions, streamflow induced from the stream to wells was 10 to 11 percent less than under long-term average annual conditions. Total stream gain in the model was reduced from $23.7 \mathrm{ft}^{3} / \mathrm{s}$ under nonpumping conditions to $11.9 \mathrm{ft}^{3} / \mathrm{s}$ during development alternative 8 and to $9.0 \mathrm{ft}^{3} / \mathrm{s}$ during development alternative 9 . No stream reaches became dry, and reduction in saturated thickness of the aquifer was less than 25 percent. Results of simulation of development alternatives 8 and 9 demonstrate that the upper Wood River ground-water reservoir can sustain an averagedaily yield of $10 \mathrm{Mgal} / \mathrm{d}$ by using different combinations of wells under drought conditions.

\section{Development alternative 10}

Wells were pumped at the same rates as in development alternative 5 under long-term average annual conditions to test the maximum capacity of 11 well sites in the upper Wood River ground-water reservoir to sustain a pumping rate of $12 \mathrm{Mgal} / \mathrm{d}$ under drought conditions. Results of the simulations show that the upper Wood River ground-water reservoir can sustain a maximum yield of $12 \mathrm{Mgal} / \mathrm{d}$ from 11 wells under drought conditions.

During development alternative 10, nine wells were pumped at a constant rate of $1 \mathrm{Mgal} / \mathrm{d}$ and two wells were pumped at a constant rate of $1.5 \mathrm{Mgal} / \mathrm{d}$ (table 12). Well locations and contours of the steadystate-pumping water table for development alterna- tive 10 are shown in figure 34 . The areal extent of drawdowns greater than or equal to $0.5 \mathrm{ft}$ for development alternative 10 is about the same as that shown in figure 30 because pumping rates are identical for drought and long-term average annual conditions. Total pumpage of $12 \mathrm{Mgal} / \mathrm{d}$ resulted in drawdowns at pumped-well cells that ranged from 2.4 ft (at well RIW 712) to $9.6 \mathrm{ft}$ (at well EXW 510).

No stream reaches became dry during development alternative 10. Total stream gain in the model was reduced from $23.7 \mathrm{ft}^{3} / \mathrm{s}$ under nonpumping conditions to $5.4 \mathrm{ft}^{3} / \mathrm{s}$ during development alternative 10 .

The two criteria established for hypothetical pumping simulations were met under all droughtcondition simulations. Total pumpage did not cause water-level declines that would decrease the unstressed saturated thickness of the aquifer by more than 16 percent. The criterion of minimal streamflow depletion with no dry reaches was also met; no stream cells became dry along the Wood River or its tributaries. Streamflow induced from the stream to wells during pumping simulations under drought conditions was 10 percent less than under long-term average annual conditions. Sustained pumping of 12 $\mathrm{Mgal} / \mathrm{d}$ would reduce the flow of the Wood River at the Hope Valley station to $99 \mathrm{ft}^{3} / \mathrm{s}$, a reduction of 18.3 $\mathrm{ft}^{3} / \mathrm{s}$. The $7 \mathrm{Q} 10$ flow at the station is $20.4 \mathrm{ft}^{3} / \mathrm{s}$. If all the wells are developed at this extreme low-flow condition and all the pumped water is exported from the basin, little flow would remain in the stream. Model results are believed to be conservative inasmuch as simulations were done under steady-state conditions and all pumpage was assumed to be exported from the basin.

\section{Stream-Aquifer Interaction}

Differences between stream leakage for nonpumping and pumping conditions show the nature and magnitude of the interaction between the stream and the aquifer. The value of the positive number in table 14 is the amount of water that has discharged from the aquifer into the river as ground-water runoff. A negative number indicates that water from the stream has flowed into the aquifer. The value of the negative number is the amount of river water that has infiltrated the aquifer as induced recharge.

Stream leakage along the 19 stream segments shown in figure 21 is summarized for development alternatives $1,2,5,6,7$, and 10 . Table 14 shows that ground-water pumpage did not affect stream leakage along stream segments $1,2,4,6,7,14,16,17$, and 19 during any pumping scenario. It also shows that max- 

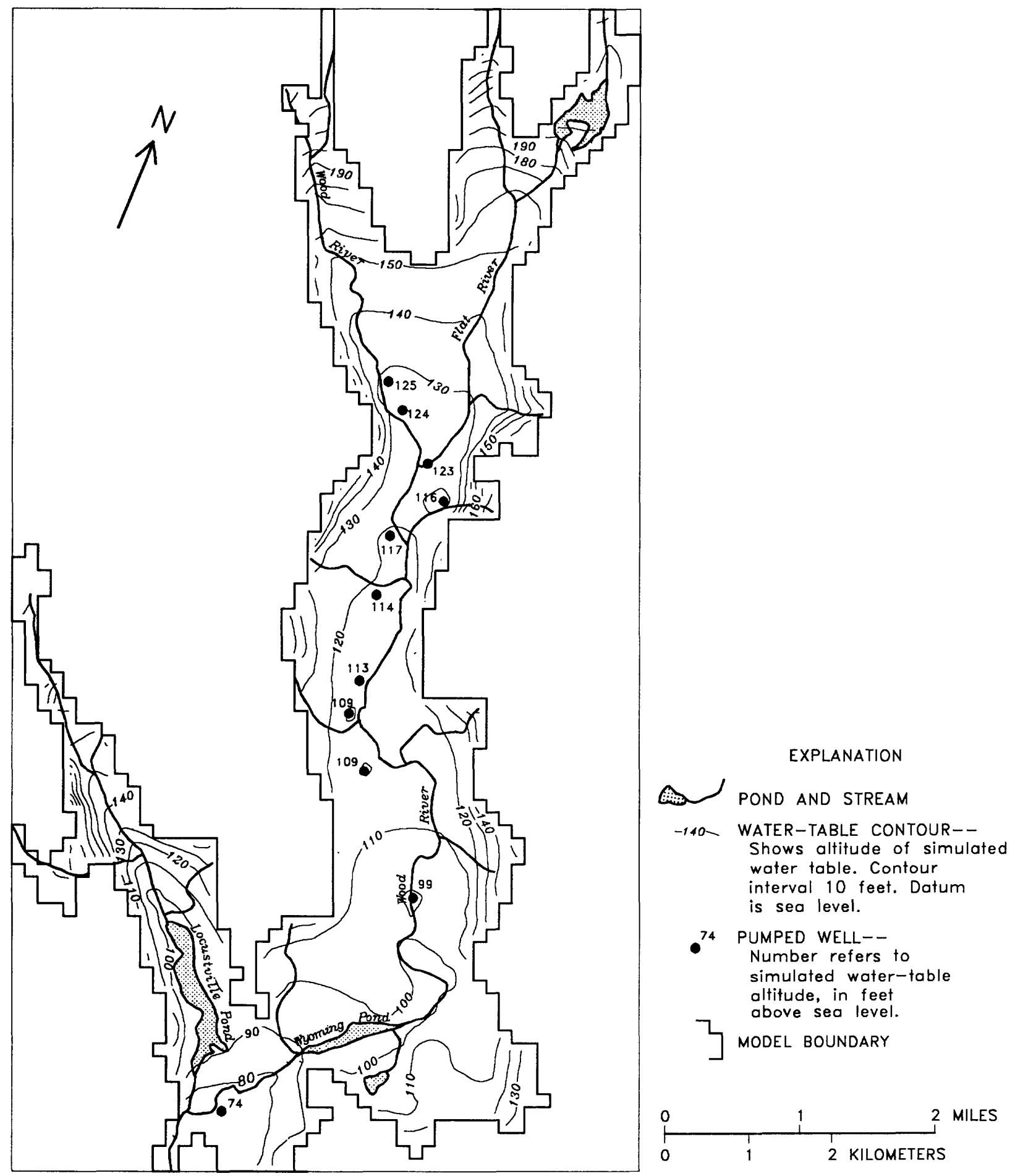

Figure 34.--Simulated steady-state water-table contours for drought conditions, development alternative 10, pumping 12 million gallons per day, upper Wood River study area. 
Table 14.--Stream leakage to or from stream segments for nonpumping and pumping conditions under selected long-term average annual and drought conditions

$\left[\mathrm{ft}^{3} / \mathrm{s}\right.$, cubic feet per second; Mgal/d, million gallons per day]

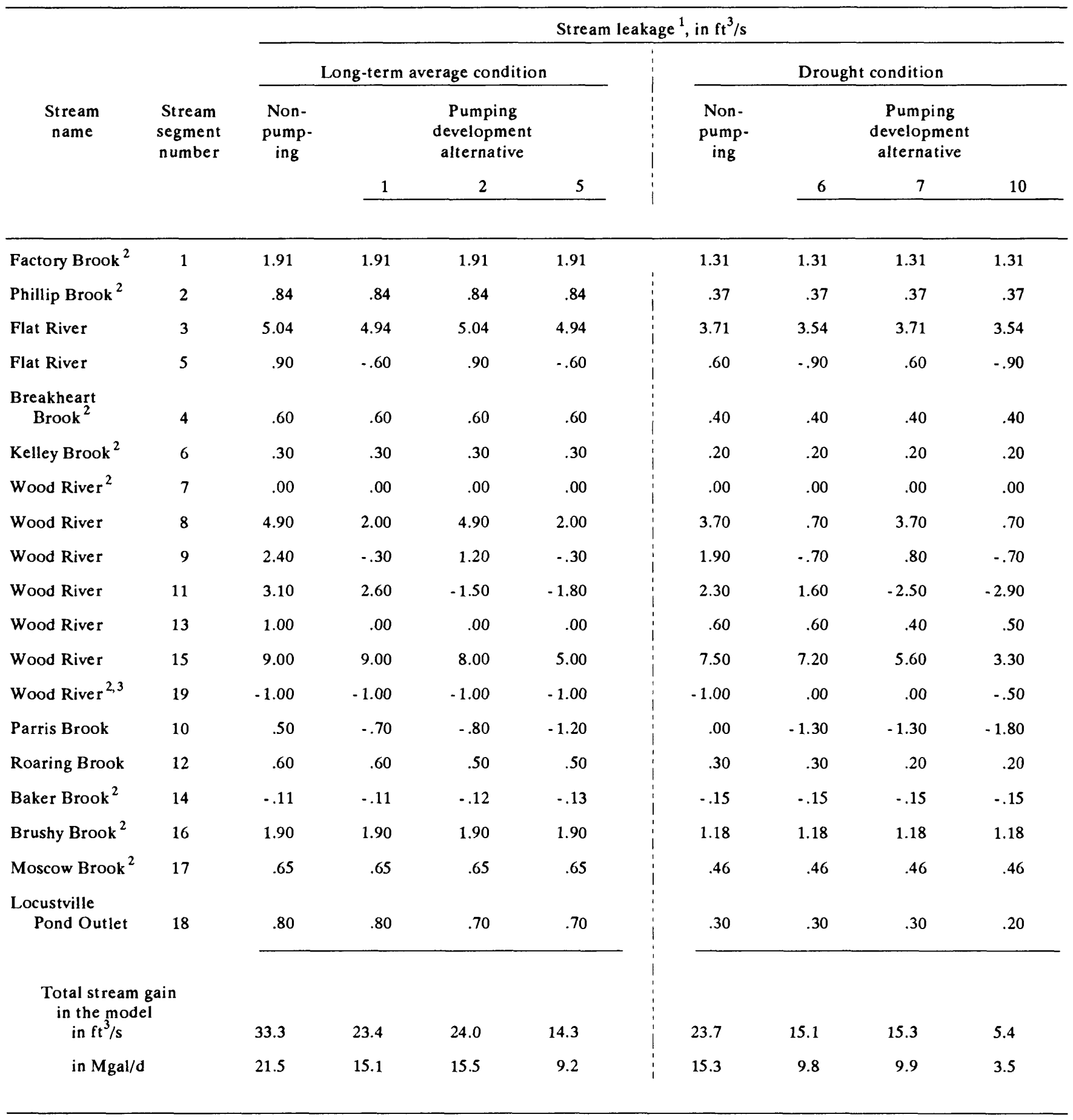

1 A positive number indicates that ground water flows from the aquifer into the stream (ground-water runoff). A negative number indicates that water from the stream flows into the aquifer (induced recharge).

2 Stream segments not affected by pumping.

${ }^{3}$ Stream-leakage loss in segment 19 is not caused by pumping during development alternatives but by pumping from a well used in the well package of MODFLOW to simulate underflow from the study area at the streamflow-gaging station on the Wood River near Hope Valley. 
imum streamflow declines occurred along stream segment 11, where the number of pumped wells (4) was at the maximum. Stream leakage from segment 11 declined by $4.90 \mathrm{ft}^{3} / \mathrm{s}$ during development alternative 5 under long-term average annual conditions and by $5.20 \mathrm{ft}^{3} / \mathrm{s}$ during development alternative 10 under drought conditions; however, no stream cells became dry during testing of development alternatives 1 through 10.

The total ground-water runoff contribution from all stream segments identified in the model was 33.3 $\mathrm{ft}^{3} / \mathrm{s}$ under long-term average annual nonpumping conditions. Under these conditions, pumping 6 $\mathrm{Mgal} / \mathrm{d}$ decreased ground-water runoff to streams by 9.2 to $9.8 \mathrm{ft}^{3} / \mathrm{s}$, and pumping $12 \mathrm{Mgal} / \mathrm{d}$ decreased ground-water runoff by $18.9 \mathrm{ft}^{3} / \mathrm{s}$.

Under drought nonpumping conditions, the total ground-water-runoff contribution from all stream segments identified in the model was 23.7 $\mathrm{ft}^{3} / \mathrm{s}$. Under these conditions, pumping $6 \mathrm{Mgal} / \mathrm{d}$ decreased ground-water runoff to streams by 8.4 to $8.6 \mathrm{ft}^{3} / \mathrm{s}$, and pumping $12 \mathrm{Mgal} / \mathrm{d}$ decreased groundwater runoff by $18.3 \mathrm{ft}^{3} / \mathrm{s}$.

\section{Sources of Pumped Water}

In the upper Wood River stratified-drift aquifer, the amount of water that a well derives from intercepted ground-water runoff, induced recharge from streamflow, or reduced evaporation and transpiration is highly variable and depends on the distance of the well from the river. Results of simulation of pumping scenarios tested show that 98 to 99 percent of all ground-water pumpage simulated under longterm average annual or drought conditions would be derived from a combination of intercepted groundwater runoff and induced stream infiltration. The remaining 1 to 2 percent would be derived from reduced evaporation and transpiration.

Results of simulation of development alternatives tested under long-term average annual conditions show that the source of water derived from intercepted ground-water runoff ranged from 33 to 40 percent of the total water pumped. The amount of well water derived from induced recharge of streamflow ranged from 59 to 65 percent. Results of simulation of development alternatives tested under drought conditions show that the source of water derived from intercepted ground-water runoff ranged from 44 to 49 percent of the total water pumped. The amount of well water derived from induced recharge of streamflow ranged from 50 to 54 percent. Sources and relative percentages of water withdrawn from wells for all development alternatives are summarized in table 15.

Table 15 shows that less water is induced from the stream by wells during drought conditions than during long-term average annual conditions, and that the amount of water derived from intercepted ground-water runoff increases during drought conditions. This was because the pumping rate remained the same during drought and long-term average annual conditions and because less stream water was available to wells through induced infiltration during drought conditions. The cone of pumping influence of the wells changed shape and slightly increased in areal extent under drought conditions, and a larger percentage of water was therefore derived from intercepted ground-water runoff.

Generally, the closer a well is to a surface-water body, the larger the percentage of water derived through induced recharge from that surface-water body. Conversely, the farther the well is from the surface-water body, the smaller the percentage of water derived through induced recharge from that surfacewater body and the greater the amount derived from intercepted ground-water runoff. Intercepted ground-water runoff is water that is moving in the ground-water-flow system toward a stream but is intercepted by a pumped well before it discharges to the stream as ground-water runoff.

Table 15 shows that for all development alternatives, 50 percent or more of the water pumped from wells was derived primarily from induced recharge from streams. Surface water in the study area is generally of suitable quality for most uses; therefore, induced recharge is not expected to have an adverse effect on ground-water quality. In the future, however, maintaining the quality of ground water in the upper Wood River area depends on maintaining the quality of stream water. In places where organic material covers pond or stream bottoms, water induced through these materials into the aquifer may undergo changes that could increase concentrations of iron or manganese in the ground water (Johnston and Dickerman, 1985, p. 61).

\section{Estimates of Areas in the Stratified Drift Contributing Water to Selected Pumped Wells}

The risk of contaminating ground-water supplies can be minimized by delineation of areas contributing water to wells and protection of these areas from land-use practices that are incompatible with the development of potable ground water. Areas in 
Table 15.--Source and relative percentages of water withdrawn from wells during ground-waterdevelopment alternatives 1 through 10

[Mgal/d, million gallons per day]

\begin{tabular}{ccccc}
\hline & & \multicolumn{3}{c}{$\begin{array}{c}\text { Amount of water derived from given source, } \\
\text { in percent of total withdrawal }\end{array}$} \\
\cline { 3 - 5 } $\begin{array}{c}\text { Development } \\
\text { alternative }{ }^{1}\end{array}$ & $\begin{array}{c}\text { Pumpage, } \\
\text { in } \\
\text { Mgal/d }\end{array}$ & $\begin{array}{c}\text { Intercepted } \\
\text { ground-water } \\
\text { runoff }{ }^{2}\end{array}$ & $\begin{array}{c}\text { Induced } \\
\text { recharge from } \\
\text { the stream }\end{array}$ & $\begin{array}{c}\text { Reduction in } \\
\text { evaporation and } \\
\text { transpiration }\end{array}$ \\
\hline & & Long-term average annual conditions & 1 \\
1 & 6 & 40 & 59 & 2 \\
2 & 6 & 33 & 65 & 1 \\
3 & 8 & 36 & 63 & 2 \\
4 & 10 & 37 & 61 & 2 \\
5 & 12 & 38 & 60 & 1 \\
6 & & Drought conditions & & 2 \\
7 & 6 & 49 & 50 & 1 \\
8 & 6 & 44 & 54 & 1 \\
9 & 8 & 47 & 52 & 2 \\
10 & 10 & 48 & 51 & 5 \\
\hline
\end{tabular}

${ }^{1}$ See table 12 for summary of data on individual pumping sites, pumping rates, and pumping conditions simulated.

${ }^{2}$ Water that would have discharged into streams as ground-water runoff, but was intercepted by pumping wells before it reached the stream.

the stratified drift contributing water to selected pumped wells in the upper Wood River ground-water reservoir were delineated by use of the particletracking algorithm MODPATH (Pollock, 1989). MODPATH computes ground-water path lines on the basis of output from steady-state simulations from MODFLOW.

MODPATH has limitations that must be understood if it is to be used effectively. These limitations are due to (1) underlying assumptions of the method, (2) discretization effects, and (3) uncertainty in parameters and boundary conditions used in MODPATH. (See Pollock, (1989, p. 19-21) for a detailed explanation of program limitations due to method assumptions and discretization effects.) The most important limitation is the uncertainty in boundary conditions and hydrogeologic parameters. In the upper Wood River ground-water-reservoir study, boundary conditions and hydrogeologic parameters used to define the ground-water-flow system are fairly well known from results of extensive test drilling, aquifer tests, and seismic surveys. Therefore, estimated areas in the stratified drift contributing water to pumped wells in the upper Wood River groundwater reservoir are most likely representative of conditions as described in this report.

In the upper Wood River model, three-dimensional particle tracking was done on a one-layer, twodimensional finite-difference model. Vertical flow was accounted for by coding recharge, evapotranspiration, and stream packages used in MODFLOW so that flows were assigned to the top face of cells. Pumped wells were treated as internal sinks and recharge wells (used to simulate lateral flow) were coded so that MODPATH could search and apply flow across the correct cell face. Endpoint and start- 
ing-point analyses were done, and two particles were placed on the top face of each cell in the row and column direction. Particles were tracked forward in the direction of flow and allowed to pass through cells coded as weak sinks.

Three development alternatives from the upper Wood River ground-water-reservoir model study were selected to show the potential of using a numerical ground-water model (MODFLOW) in conjunction with the particle tracker (MODPATH) to estimate contributing areas to pumped wells. Areas that contribute water to wells are delineated only for the stratified-drift aquifer and do not show that part of the contributing area that would extend beyond the model boundary, because the numerical model does not extend into the till/bedrock uplands. In the following examples (figs. 35-37), blank areas are shown at some places within contributing areas for individual wells. Blank areas are located at discharge cells where particles cannot move downward because water is discharging to streams, ponds, or swamps.

The first example involves MODFLOW output from development alternatives 1 and 2 . Figures 35 and 36 show the estimated areas in the stratified drift contributing water to wells for simulated pumpage of $6 \mathrm{Mgal} / \mathrm{d}$ during development alternatives 1 and 2 . Six wells in the northern part of the basin were pumped in development alternative 1 , and six wells in the southern part of the basin were pumped in development alternative 2 . These simulated alternatives were chosen to show estimated areas in the stratified drift contributing water to wells for similar pumpage from the northern and southern parts of the upper Wood River study area.

The second example involves MODFLOW output from development alternative 5. Figure 37 shows the estimated area in the stratified drift contributing water to wells for simulated pumpage of $12 \mathrm{Mgal} / \mathrm{d}$ during development alternative 5. For this alternative, pumpage was distributed among 11 wells throughout the area of the upper Wood River ground-water reservoir. Development alternative 5 was chosen to show estimated areas in the stratified drift contributing water to wells during maximum simulated pumpage in the basin.

Figures derived from MODPATH show that total contributing areas to wells encompass almost all stratified drift between model boundaries. This finding indicates that large areas of stratified drift may need to be protected from land-use practices that are incompatible with development of potable ground water in the upper Wood River ground-water reservoir.

\section{SUMMARY AND CONCLUSIONS}

The upper Wood River ground-water reservoir is one of the most pristine sources of ground water in Rhode Island. Because a large part of the groundwater reservoir is in the Arcadia State Park Management Area, it is less vulnerable to contamination than many other areas studied by the U.S. Geological Survey (USGS) in its cooperative program with the Rhode Island Water Resources Board (RIWRB). The upper Wood River ground-water reservoir is an important source of water in the Pawcatuck River basin.

The RIWRB is responsible for implementing development of the State's major water resources. It identifies sites at which high-capacity wells that yield water of suitable quality for municipal supply can be developed, and it proposes to preserve and protect these sites for future water supply. The upper Wood River ground-water-reservoir study is one of five ground-water-reservoir studies to be completed in the Pawcatuck River basin.

This report describes the hydrogeology and water quality of the upper Wood River ground-water reservoir and presents results of steady-state model simulations of ground-water-development alternatives designed to determine the potential for the stratified-drift aquifer to yield $1 \mathrm{Mgal} / \mathrm{d}$ or more to individual wells. The USGS ground-water-flow model, MODFLOW, was used to simulate the steadystate ground-water-flow system and its response to imposed stresses.

The upper Wood River study area is in the Pawcatuck River basin in southern Rhode Island. The 72.4- $\mathrm{mi}^{2}$ study area includes parts of the towns of Coventry, Exeter, Hopkinton, Richmond, and West Greenwich. The predominantly crystalline bedrock of the study area is covered by glacial deposits of till and stratified drift. Till is exposed at the land surface in the upland areas, and stratified drift forms broad lowlands in the major river valleys.

Stratified drift is the only geologic unit capable of producing well yields greater than $0.5 \mathrm{Mgal} / \mathrm{d}$. The upper Wood River ground-water reservoir is that part of the stratified-drift aquifer with the greatest potential for ground-water development. The saturated thickness of the stratified-drift aquifer averages $70 \mathrm{ft}$; the maximum known saturated thickness is about $125 \mathrm{ft}$. Aquifer transmissivity ranges from 7,600 to $49,200 \mathrm{ft}^{2} / \mathrm{d}$ and averages $25,100 \mathrm{ft}^{2} / \mathrm{d}$. Horizontal hydraulic conductivity ranges from 120 to $965 \mathrm{ft} / \mathrm{d}$ and averages $395 \mathrm{ft} / \mathrm{d}$. Vertical hydraulic conductivity ranges from 2 to $80 \mathrm{ft} / \mathrm{d}$ and averages 


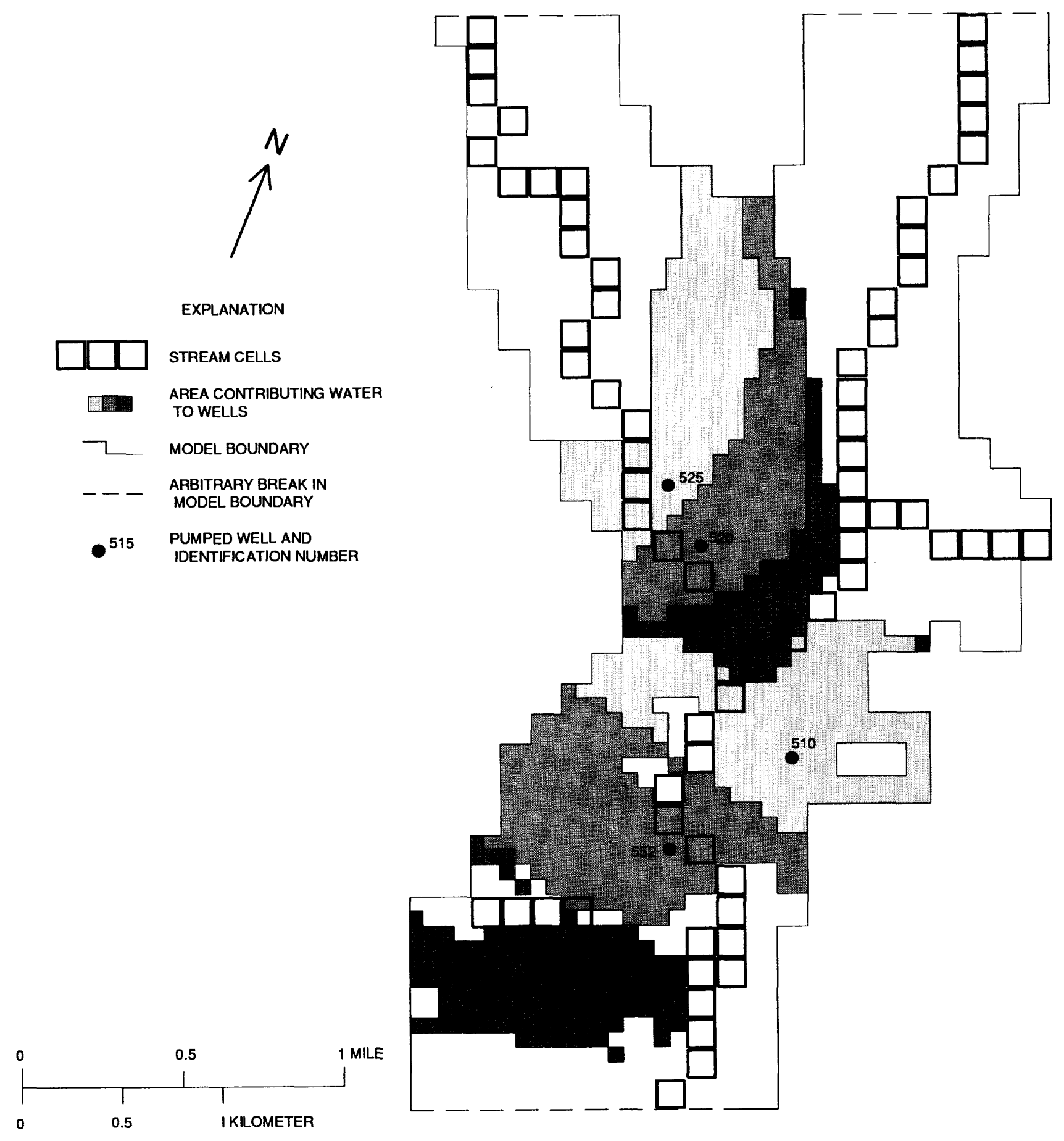

Figure 35.--Estimated areas in the stratified drift contributing water to wells pumped during development alternative 1, northern part of the upper Wood River study area. 


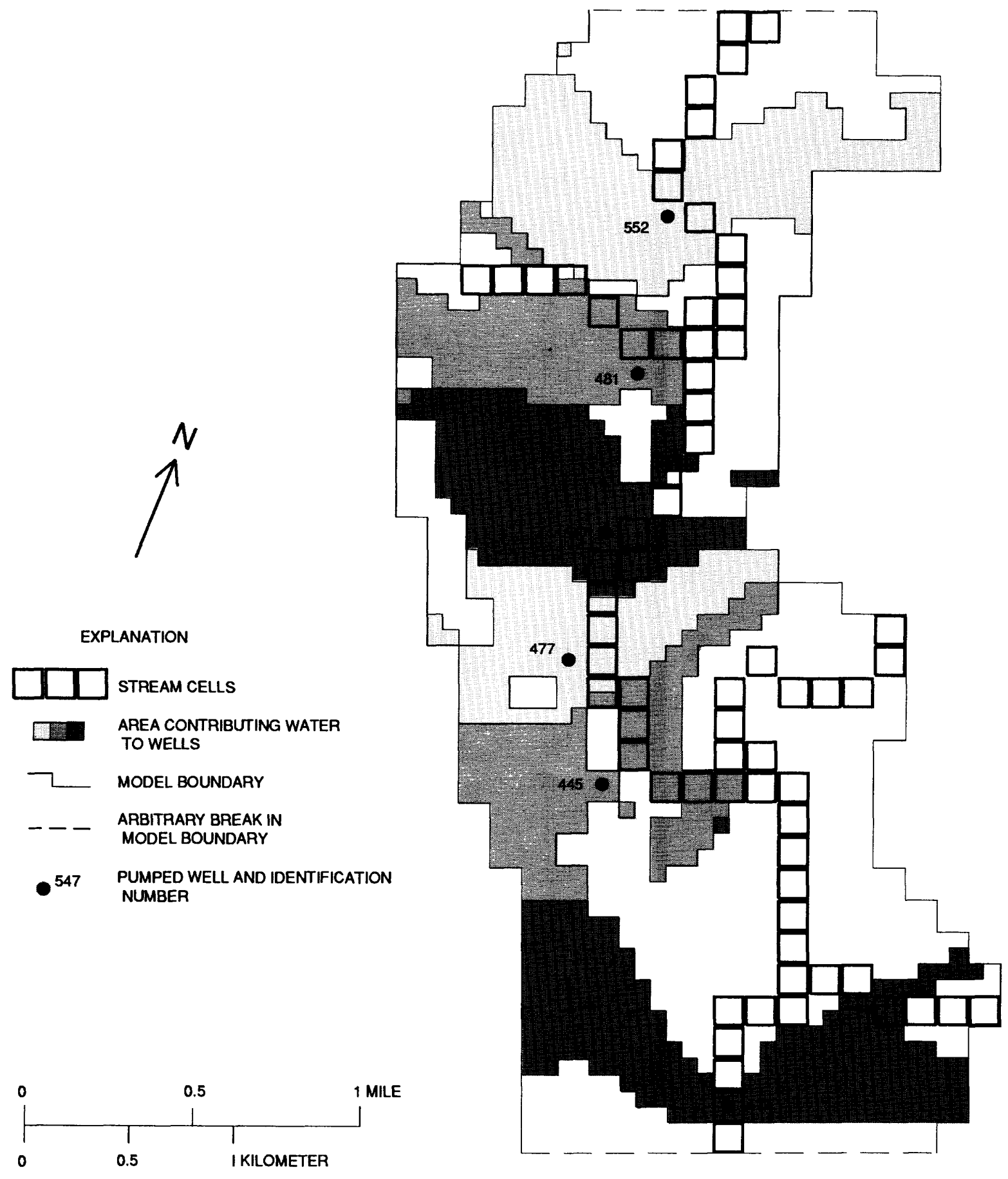

Figure 36.--Estimated areas in the stratified drift contributing water to wells pumped during development alternative 2, southern part of the upper Wood River study area. 


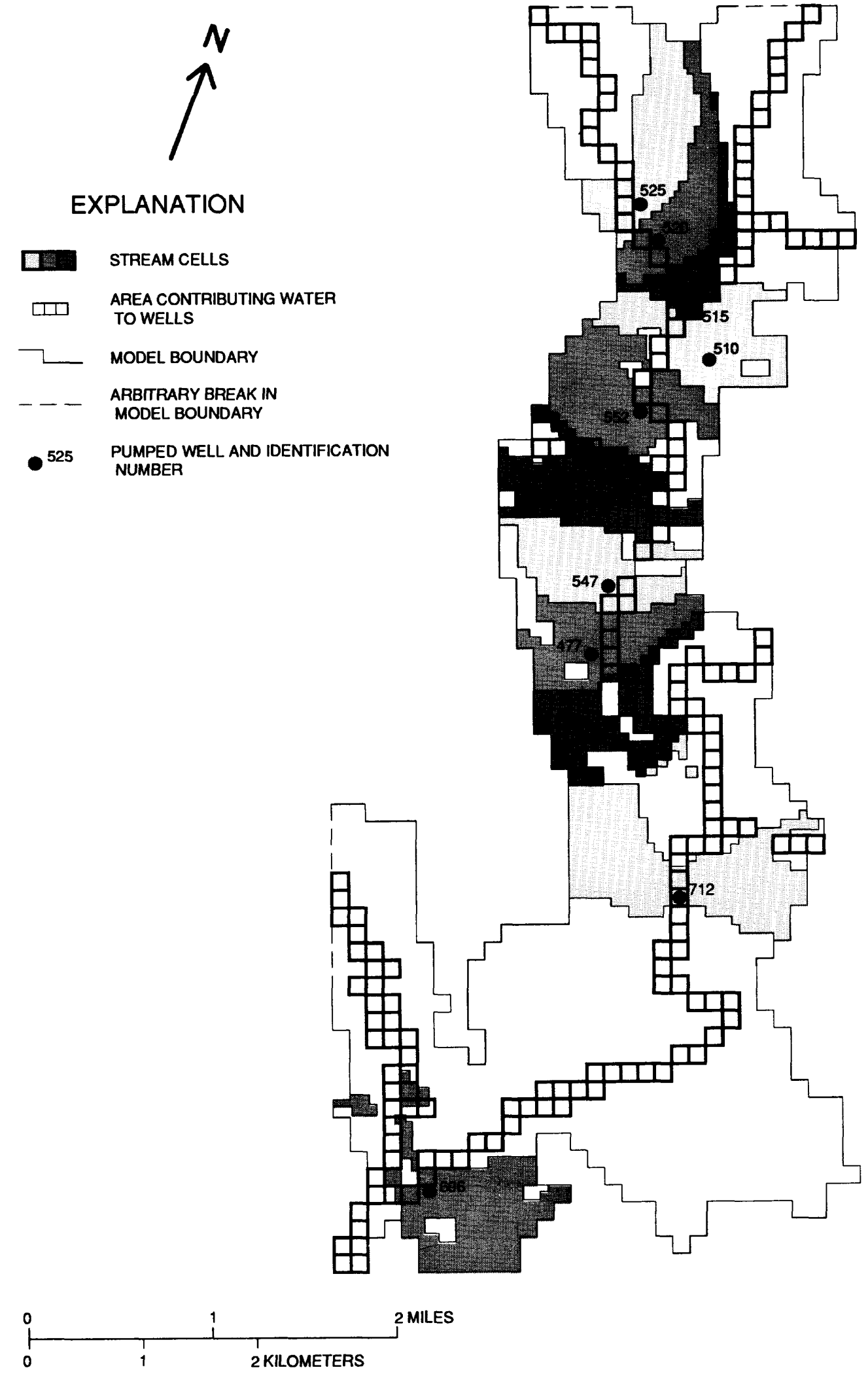

Figure 37.--Estimated areas in the stratified drift contributing water to wells pumped during development alternative 5, upper Wood River study area. 
at the downstream station near Hope Valley was 157 $\mathrm{ft}^{3} / \mathrm{s}$ (measured streamflow $156 \mathrm{ft}^{3} / \mathrm{s}$ ).

Results of sensitivity analyses indicate that water levels are significantly affected by large variations in horizontal hydraulic conductivity of the aquifer, large decreases in vertical hydraulic conductivity of the streambed, and large increases in recharge from precipitation. Results of the analyses also indicate that streamflow gain between gaging stations is most sensitive to large increases in precipitation recharge and to increases or decreases in streamflow.

Ground-water-development alternatives were simulated under long-term average annual and drought conditions at 11 well sites in the upper Wood River ground-water reservoir. Total pumpage for development-alternative simulations ranged from 6 to $12 \mathrm{Mgal} / \mathrm{d}$. Individual wells were pumped at constant rates of 1 or $1.5 \mathrm{Mgal} / \mathrm{d}$ during simulations. Model results are believed to be conservative because simulations were done under steady-state conditions, and all pumpage was assumed to be exported from the study area. If pumpage were returned to the flow system upstream from withdrawal points rather than exported from the study area, ground-waterlevel and streamflow declines would be less than predicted.

The objective of pumping simulations was to test the maximum pumping capacity of 11 well sites in the upper Wood River ground-water reservoir without (1) causing water-level declines of more than 25 percent of the unstressed saturated thickness of the aquifer or (2) causing flow in any stream reach to cease.

Results of simulation of development alternatives 1 and 2 show that the upper Wood River ground-water reservoir can sustain an average daily yield of $6 \mathrm{Mgal} / \mathrm{d}$ from either the northern or southern part of the basin with minimal effect on streamflow and ground-water levels under long-term average annual conditions. Results of simulation of increased pumpage, tested in development alternatives 3 and 4, show that the upper Wood River ground-water reservoir is also capable of sustaining an average daily yield of 8 or $10 \mathrm{Mgal} / \mathrm{d}$ under longterm average annual conditions. Results of simulation of development alternatives 3 and 4 demonstrate that the upper Wood River ground-water reservoir can sustain an average daily yield of $10 \mathrm{Mgal} / \mathrm{d}$ using different combinations of wells under long-term average annual conditions.

Ground-water withdrawals were gradually increased to test the maximum pumping capacity of 11 well sites in the upper Wood River ground-water reservoir under long-term average annual conditions. Results of simulation of development alternative 5 show that the upper Wood River ground-water reservoir can sustain a maximum yield of $12 \mathrm{Mgal} / \mathrm{d}$ from 11 wells at sites tested in the field. Sustained pumping of $12 \mathrm{Mgal} / \mathrm{d}$, however, would reduce the flow of the Wood River at the Hope Valley gaging station by $18.9 \mathrm{ft}^{3} / \mathrm{s}$, an amount almost equal to the 7Q10 (20.4 $\left.\mathrm{ft}^{3} / \mathrm{s}\right)$.

Drought conditions were simulated in the model by reducing long-term average annual recharge from precipitation, inflow from till-covered bedrock uplands, and streamflow by 25 percent. This percentage reduction approximates the 1963-66 drought, a period considered representative of extreme drought conditions.

Results of simulation of development alternatives 6 and 7 show that the upper Wood River ground-water reservoir can sustain an average daily yield of $6 \mathrm{Mgal} / \mathrm{d}$ from either the northern or the southern part of the basin with minimal effect on streamflow and ground-water levels under drought conditions. Results of simulation of development alternatives 8 and 9 demonstrate that the upper Wood River ground-water reservoir can sustain an average daily yield of $10 \mathrm{Mgal} / \mathrm{d}$ using different combinations of wells under drought conditions.

Results of simulation of development alternative 10 indicate that the upper Wood River ground-water reservoir can sustain a maximum yield of $12 \mathrm{Mgal} / \mathrm{d}$ under drought conditions from 11 wells at sites tested in the field. Sustained pumping of $12 \mathrm{Mgal} / \mathrm{d}$, however, would reduce the flow of the Wood River at the Hope Valley gaging station by $18.3 \mathrm{ft}^{3} / \mathrm{s}$, an amount approximately equal to the $7 \mathrm{Q} 10\left(20.4 \mathrm{ft}^{3} / \mathrm{s}\right)$.

Differences between stream leakage for nonpumping and pumping conditions show the nature and magnitude of the interaction between the stream and the aquifer. Simulated ground-water pumpage did not affect stream leakage along Factory Brook, Phillip Brook, Breakheart Brook, Kelly Brook, Baker Brook, Brushy Brook, Moscow Brook, or two segments of the Wood River (one near the Hope Valley station and the other upstream from the confluence with Kelly Brook) during any pumping scenario. Maximum streamflow declines occurred along stream segment 11 on the Wood River, where stream leakage declined by $5.2 \mathrm{ft}^{3} / \mathrm{s}$ while $12 \mathrm{Mgal} / \mathrm{d}$ was pumped from 11 wells during drought simulations. No stream cells became dry during testing of development alternatives 1 through 10; however, sustained pumping of $12 \mathrm{Mgal} / \mathrm{d}$, tested in development alternatives 5 and 10, would reduce the flow of the Wood River at the Hope Valley station by 18 to 19 
$16 \mathrm{ft} / \mathrm{d}$. Unconfined conditions prevail in the aquifer, which is in hydraulic connection with perennial streams and ponds. The sites most favorable for development of high-capacity wells (those capable of yielding $1 \mathrm{Mgal} / \mathrm{d}$ or more) are along the floodplains of the Flat and Wood Rivers.

Water available for recharge is generally equal to annual runoff (precipitation minus evaporation and transpiration). Annual precipitation during 1942-89 averaged $47.6 \mathrm{in}$. Of this amount, $29.4 \mathrm{in}$. discharges to the stream as runoff and the rest (18.2 in.) is returned to the atmosphere by evaporation and transpiration. In simulations of flow in the groundwater reservoir, recharge was not applied to areas in the upper Wood River where the water table was at land surface. Recharge was applied at a rate of 29 in/yr to the stratified drift for long-term average annual conditions, which is equivalent to a rate of about $21 \mathrm{in} / \mathrm{yr}$ when evenly distributed.

Long-term (1942-89) annual runoff averaged $157 \mathrm{ft}^{3} / \mathrm{s}$ on the Wood River at the USGS streamflowgaging station just south of Hope Valley at the downstream end of the ground-water reservoir. The 7-day low flow with a 10 -year recurrence interval (7Q10) at the Hope Valley station is $20.4 \mathrm{ft}^{3} / \mathrm{s}$, which is about equivalent to the 99.1-percent flow duration $\left(20.2 \mathrm{ft}^{3} / \mathrm{s}\right)$.

Water use in the study area was estimated to be about $0.34 \mathrm{Mgal} / \mathrm{d}$ during 1989; all withdrawals were ground water. Pumpage from domestic wells accounted for about 92 percent of the ground water withdrawn during 1989. No public sewage-treatment facilities were operating in the study area in 1989.

In terms of water quality, ground water and surface water in the upper Wood River study area are suitable for drinking and most other uses. Concentrations of inorganic constituents, metals, and organic compounds in water samples from wells were generally below the maximum contaminant levels (MCL's) established by the R.I. Department of Health (RIDOH). Most stream segments of the upper Wood River and its tributaries are designated by RIDOH as either "Class A" or "Class B." (Waterbodies in compliance with Class $A$ and B standards are suitable for use as sources of drinking water.)

Although much of the study area is undeveloped land where water quality is virtually unaffected by human activity, various land-use and waste-disposal practices have resulted in local ground-water contamination. Concentrations of nitrate and chloride were elevated above background concentrations in water samples from some wells; however, the concentrations did not exceed the MCL for nitrate or the RIDOH secondary MCL (SMCL) for chloride.
Volatile organic compounds have been detected in ground water near leaky gasoline-storage tanks in the Canob Park area. Elevated concentrations of iron and manganese in water from some wells in the southern and central parts of the study area were equal to or exceeded the RIDOH SMCL. The Wood River at Hope Valley is the only stream segment in the basin designated as "Class C." (Waterbodies in compliance with Class $\mathrm{C}$ standards are suitable only for secondary-contact recreational activities, fish and wildlife habitat, and industrial processes.) This degradation of water quality is believed to be caused by substandard or failing septic systems.

Results of seasonal Kendall trend tests indicated a slight increase in the specific conductance of stream water in the Wood River at Hope Valley for water years 1978 through 1989 . Elevated concentrations of chloride were measured in water samples collected from six streams near roads to which deicing salt is applied. Although these streams contained chloride in concentrations that were high with respect to background concentration $(2.9 \mathrm{mg} / \mathrm{L})$, the chloride concentration exceeded the SMCL of 250 $\mathrm{mg} / \mathrm{L}$ at only one site. The specific cause of these increases was not identified in this study but may be related to changes in land-use practices or application of deicing salt.

A digital model was constructed to simulate ground-water flow in the upper Wood River groundwater reservoir. Most model boundaries coincide closely with geologic contacts between the stratified drift and the till-covered bedrock valley walls; these were treated as specified-flux boundaries. The bottom boundary of the aquifer, the contact between the highly permeable stratified drift and the less permeable till-covered bedrock, was modeled as a no-flow boundary. A leaky-boundary condition was assigned to the Wood River and its tributary streams to simulate the interaction of the stream and the aquifer.

The model was calibrated by comparing computed and measured water-table altitudes in wells and by comparing model-determined streamflow and measured discharge at two streamflow-gaging stations. Differences between computed and measured water-table altitudes in 37 observation wells were less than $3 \mathrm{ft}$ at 57 percent of the observation-well cells. The mean absolute error of residuals is $3.0 \mathrm{ft}$, and the root mean square error is $3.7 \mathrm{ft}$. Simulated flow was in close agreement with long-term average annual streamflow throughout the study area. Simulated steady-state streamflow from the model at the upstream gaging station on the Wood River at Arcadia was $76 \mathrm{ft}^{3} / \mathrm{s}$ (estimated streamflow $77 \mathrm{ft}^{3} / \mathrm{s}$ ) and 
$\mathrm{ft}^{3} / \mathrm{s}$. The $7 \mathrm{Q} 10$ at the station is $20.4 \mathrm{ft}^{3} / \mathrm{s}$. If all the wells are developed and all the pumped water is exported from the basin, little flow would remain in the stream at this extreme low-flow condition.

Simulations indicate that 98 to 99 percent of all ground-water pumpage simulated under long-term average annual or drought conditions would be derived from a combination of intercepted groundwater runoff and induced stream infiltration. Results of simulation of development alternatives under long-term average annual conditions show that 59 to 65 percent of all water withdrawn from wells is derived from induced recharge and that 33 to 40 percent is derived from intercepted ground-water runoff. Results of simulation of development alternatives under drought conditions show that 50 to 54 percent of all water withdrawn from wells is derived from induced recharge and that 44 to 49 percent is derived from intercepted ground-water runoff. The remaining 1 to 2 percent is derived from reduced evaporation and transpiration for long-term average annual and drought conditions.

The risk of contaminating ground-water supplies can be minimized by delineation of areas contributing water to wells and protection of these areas from land-use practices that are incompatible with the development of a potable ground water. Areas in the stratified drift contributing water to selected pumped wells in the upper Wood River ground-water reservoir were delineated by means of a particletracking algorithm MODPATH.

The upper Wood River ground-water reservoir is a valuable resource to the State of Rhode Island and an important source of potable water in the Pawcatuck River basin; however, because the areas most favorable for development of high-capacity wells are along streams, the maintenance of high-quality ground water in the upper Wood River area depends on the continued high quality of stream water.

\section{REFERENCES CITED}

Allen, W.B., Hahn, G.W., and Tuttle, C.R., 1963, Geohydrological data for the upper Pawcatuck River basin, Rhode Island: Rhode Island Water Resources Coordinating Board Geological Bulletin 13, 68 p.

Allen, W.B., and Kinnison, H.B., 1953, The groundwater resources of Rhode Island: Rhode Island Development Council Geological Bulletin 6, $170 \mathrm{p}$.
Bierschenk, W.H., and Hahn, G.W., 1959, Groundwater map of Hope Valley quadrangle, Rhode Island: Rhode Island Water Resources Coordinating Board GWM-6, scale 1:24,000.

Biesecker, J.E., and Leifeste, D.K., 1975, Water quality of hydrologic benchmarks--An indicator of water quality in the natural environment: U.S. Geological Survey Circular 460-E, 21 p.

Cooper, H.H., Jr., and Jacob, C.E., 1946, A generalized graphical method for evaluating formation constants and summarizing well-field history: American Geophysical Union, Transactions, v. 27, no. 4 , p. 526-534.

Dickerman, D.C., 1984, Aquifer tests in the stratified drift, Chipuxet River basin, Rhode Island: U.S. Geological Survey Water-Resources Investigations Report 83-4231, 39 p.

Dickerman, D.C., Bell, R.W., Mulvey, K.D., Peterman, E.L., and Russell, J.P., 1989, Geohydrologic data for the upper Wood River ground-water reservoir, Rhode Island: Rhode Island Water Resources Board Water Information Series Report 5, 274 p., 2 pls.

Dickerman, D.C., Trench, E.C.T., and Russell, J.P., 1990, Hydrogeology, water quality, and groundwater development alternatives in the lower Wood River ground-water reservoir, Rhode Island: U.S. Geological Survey Water-Resources Investigations Report 89-4031, 109 p.

Feininger, T.G., 1962, Surficial geology of the Hope Valley quadrangle, Rhode Island: U.S. Geological Survey Geologic Quadrangle GQ-166, scale 1:31,680.

-.-- 1965a, Bedrock geology of the Voluntown quadrangle, Connecticut-Rhode Island: U.S. Geological Survey Geologic Quadrangle GQ-436, scale $1: 24,000$.

--.- 1965b, Surficial geology of the Voluntown quadrangle, Connecticut-Rhode Island: U.S. Geological Survey Geologic Quadrangle GQ-469, scale $1: 24,000$.

Fenneman, N.M., 1938, Physiography of Eastern United States: New York, McGraw-Hill Book Company, $714 \mathrm{p}$.

Ferris, J.G., Knowles, D.B., Brown, R.H., and Stallman, R.W., 1962, Theory of aquifer tests: U.S. Geological Survey Water-Supply Paper 1536-E, $174 \mathrm{p}$ 
Gonthier, J.B., Johnston, H.E., and Malmberg, G.T., 1974, Availability of ground water in the lower Pawcatuck River basin, Rhode Island: U.S. Geological Survey Water-Supply Paper 2033, 40 p., 4 pls.

Harwood, D.S., and Goldsmith, Richard, 1971a, Surficial geology of the Oneco quadrangle, Connecticut-Rhode Island: U.S. Geological Survey Geologic Quadrangle GQ-917, scale 1:24,000.

---- 1971b, Bedrock geology of the Oneco quadrangle, Connecticut-Rhode Island: U.S. Geological Survey Geologic Quadrangle GQ-930, scale $1: 24,000$.

Hazen, Allen, 1892, A new color standard for natural waters: American Chemical Journal, v. 12, p. 427-428.

Hem, J.D., 1985, Study and interpretation of the chemical characteristics of natural water (3d ed.): U.S. Geological Survey Water-Supply Paper 2254, $263 \mathrm{p}$.

Hirsch, R.M., Slack, J.R., and Smith, R.A., 1982, Techniques of trend analysis for monthly water quality data: Water Resources Research, v. 18, no. 1 , p. 107-121.

Irelan, Burdge, and Mendieta, H.B., 1964, Chemical quality of surface waters in the Brazos River basin in Texas: U.S. Geological Survey WaterSupply Paper 1779-K, 70 p.

Johnson, K.E., Mason, R.A., and DeLuca, F.A., 1960, Ground-water map of the Oneco quadrangle, Connecticut-Rhode Island: Rhode Island Water Resources Coordinating Board GWM10 , scale $1: 24,000$.

Johnston, H.E., and Barlow, P.M., 1988, Rhode Island ground-water quality, in National Water Summary 1986--Ground-water quality: U.S. Geological Survey Water-Supply Paper 2325, p. 443-448.

Johnston, H.E., and Dickerman, D.C., 1985, Hydrology, water quality, and ground-water-development alternatives in the Chipuxet ground-water reservoir, Rhode Island: U.S. Geological Survey Water-Resources Investigations Report 844254, 100 p., 1 pl.

Konikow, L.F., 1978, Calibration of ground-water models, in Specialty conference on verification of mathematical and physical models in hydraulic engineering, College Park, Md., August 9-11, Proceedings: American Society of Civil Engineers, p. 87-93.
Lang, S.M., 1961, Appraisal of the ground-water reservoir areas in Rhode Island: Rhode Island Water Resources Coordinating Board Geological Bulletin 11, $38 \mathrm{p}$.

LaSala, A.M., and Hahn, G.W., 1960, Ground-water map of the Carolina quadrangle, Rhode Island: Rhode Island Water Resources Coordinating Board GWM-9, scale 1:24,000.

Lohman, S.W., and others, 1972, Definitions of selected ground-water terms--Revisions and conceptual refinements: U.S. Geological Survey Water-Supply Paper 1988, 21 p.

Lohman, S.W., 1979, Ground-water hydraulics: U.S. Geological Survey Professional Paper 708, 70 p., 9 pls.

Lyford, F.P., and Cohen, A.J., 1988, Estimation of water available for recharge to sand and gravel aquifers in the glaciated northeastern United States, in Randall, A.D., and Johnson, A.I., eds., Regional aquifer systems of the United States-Northeast glacial aquifers: American Water Resources Association Monograph Series 11, p. 37-62.

Mason, R.A., and Hahn, G.W., 1960, Ground-water map of the Coventry Center quadrangle, Rhode Island: Rhode Island Water Resources Coordinating Board GWM-8, scale 1:24,000.

MçDonald, M.G., and Harbaugh, A.W., 1988, A modular three-dimensional finite-difference ground-water flow model: U.S. Geological Survey Techniques of Water-Resources Investigations, book 6, chap. A1, 589 p.

Moore, G.E., Jr., 1958, Bedrock geology of the Hope Valley quadrangle, Rhode Island: U.S. Geological Survey Geologic Quadrangle GQ-105, scale $1: 31,680$.

-... 1959, Bedrock geology of the Carolina and Quonochontaug quadrangles, Rhode Island: U.S. Geological Survey Geologic Quadrangle GQ-117, scale 1:31,680.

--.- 1963, Bedrock geology of the Coventry Center quadrangle, Rhode Island: U.S. Geological Survey Bulletin 1158-A, 24 p., 1 pl.

Pluhowski, E.J., and Kantrowitz, I.H., 1964, Hydrology of the Babylon-Islip area, Suffolk County, Long Island, New York: U.S. Geological Survey Water-Supply Paper 1768, 119 p. 
Pollock, D.W., 1989, Documentation of computer programs to compute and display pathlines using results from the U.S. Geological Survey modular three-dimensional finite-difference ground-water flow model: U.S. Geological Survey Open-File Report 89-381, 188 p.

Prudic, D.E., 1989, Documentation of a computer program to simulate stream-aquifer relations using a modular, finite-difference, ground-water flow model: U.S. Geological Survey Open-File Report 88-729, 113 p.

Randall, A.D., Bierschenk, W.H., and Hahn, G.W., 1960, Ground-water map of the Voluntown quadrangle, Connecticut-Rhode Island: Rhode Island Water Resources Coordinating Board GWM-13, scale $1: 24,000$.

Randall, A.D., Thomas, M.P., Thomas, C.E., Jr., and Baker, J.A., 1966, Water resources inventory of Connecticut, pt. 1, Quinebaug River basin: Connecticut Water Resources Bulletin 8, 101 p., 4 pls.

Rhode Island Department of Environmental Management, 1990, The state of the State's waters-Rhode Island: A report to Congress, PL 92-500, 305 (b), $710 \mathrm{p}$.

Rhode Island Department of Health, 1991, Rules and regulations pertaining to public drinking water: Division of Drinking Water Quality, R.I. Department of Health, section 16, p. 38-61.

Rhode Island Statewide Planning Program, 1979, 208 water quality management plan for Rhode Island: Final plan, 468 p., 3 pls.

Rhode Island Statewide Planning Program and Rhode Island Department of Health, 1976, Water quality management plan for the Pawcatuck River basin: Rhode Island Statewide Planning Program Report 26 E, 136 p.

Smith, R.A., Hirsch, R.M., and Stack, J.R., 1982, A study of trends in total phosphorus at NASQAN stations: U.S. Geological Survey Water-Supply Paper 2190, $34 \mathrm{p}$.

Stallman, R.W., 1963, Electric analog of threedimensional flow to wells and its application to unconfined aquifers: U.S. Geological Survey Water-Supply Paper 1536-H, 38 p.

1965, Effects of water table conditions on water level changes near pumping wells: Water Resources Research, v. 1, no. 2, p. 295-312.
1971, Aquifer-test design, observation, and data analysis: U.S. Geological Survey Techniques of Water-Resources Investigations, book 3, chap. B1, $26 \mathrm{p}$.

Stone, B.D., and Borns, H.W., Jr., 1986, Pleistocene glacial and interglacial stratigraphy of New England, Long Island, and adjacent Georges Bank and Gulf of Maine, in Sibrava, Vladimir, Bowen, D.Q., and Richmond, G.M., eds., Quaternary glaciation in the northern hemisphere, International Geologic Correlation Program Project 24: Oxford, England, Pergamon Press, p. 39-53.

Thornthwaite, C.W., and Mather, J.R., 1957, Instruction and tables for computing potential evapotranspiration and the water balance: Drexel Institute Technical Publications in Climatology, v. 10, no. 3, 311 p.

Trescott, P.C., Pinder, G.F., and Larson, S.P., 1976, Finite-difference model for aquifer simulation in two dimensions with results of numerical experiments: U.S. Geological Survey Techniques of Water-Resources Investigations, book 7 chap. C1, 116 p.

U.S. Geological Survey, 1940-50--part 1, Surface water supply of the United States, North Atlantic slope basins, Maine to Connecticut: U.S. Geological Survey Water-Supply Papers (published annually).

-.-- 1951-1960--part 1A, Surface water supply of the United States, North Atlantic slope basins, Maine to Connecticut: U.S. Geological Survey Water-Supply Papers (published annually).

-...- 1961-1964, Surface water records of Massachusetts, New Hampshire, Rhode Island, and Vermont: U.S. Geological Survey Open-File Reports, unnumbered (published annually).

-.--1965-1974, Water resources data for Massachusetts, New Hampshire, Rhode Island, and Vermont: U.S. Geological Survey Open-File Reports, unnumbered (published annually).

...-- Since 1975, Water resources data for Massachusetts and Rhode Island: U.S. Geological Survey Water-Data Reports (published annually).

Walton, W.C., 1962, Selected analytical methods for well and aquifer evaluation: Illinois State Water Survey Bulletin 49, 81 p. 
Weinstein, H.C., Stone, H.L., and Kwan, T.V., 1969, Iterative procedure for solution of systems of parabolic and elliptic equations in three dimensions: Industrial and Engineering Chemistry Fundamentals, v. 8, no. 2, p. 281-287.

Williams, C.C., and Lohman, S.W., 1949, Geology and ground-water resources of a part of southcentral Kansas: Kansas Geological Survey Bulletin $79,455 \mathrm{p}$.

\section{GLOSSARY}

ANION: An ion that has a negative electrical charge; for example, nitrate and chloride ions are anions.

ANISOTROPY: That condition in which all hydraulic properties vary with direction.

AQUIFER: A formation, group of formations, or part of a formation that contains enough saturated permeable material to yield significant quantities of water to wells and springs.

AQUIFER TEST: A controlled field experiment wherein the effect of pumping a well is measured in the pumped well and in observation wells for the purpose of determining hydraulic properties of an aquifer.

BEDROCK: The solid rock, locally called "ledge," that underlies unconsolidated material at the Earth's surface.

CATION: An ion that has a positive electrical charge; for example, sodium and calcium ions are cations.

COLOR: Color is expressed in units of the platinum-cobalt scale proposed by Hazen (1892, p. 427-428). A unit of color is produced by one milligram per liter of platinum in the form of the chloroplatinated ion. The intensity of color is rated numerically from 0 to 500 , a color of 5 being equivalent to $1 / 100$ that of the standard. The extent to which a water is colored by material in solution may indicate the presence of organic material that may have some bearing on the dissolved-solids content.

CONCEPTUAL MODEL, of the stream-aquifer system: A general idea or understanding of a stream-aquifer system that makes realistic mathematical simulation of that system possible.

CONFINED AQUIFER (ARTESIAN AQUIFER): An aquifer in which ground water is confined under pressure significantly greater than atmospheric. See UNCONFINED AQUIFER.

CONTACT: A plane or irregular surface between two different types or ages of rocks or unconsolidated sediments.

CONTINUOUS-RECORD STREAMFLOW-GAGING STATION: A site on a stream at which continuous measurements of stream stage are made. These records are converted to daily flow after calibration by means of flow measurements.

DIGITAL MODEL: A simplified mathematical representation of a complex aquifer system. A computer program designed to solve groundwater-flow equations.

DIGITIZE: To enter explicit $x-y$ point coordinates into a computer system.

DISCHARGE: The volume of water that passes a given point in a given period of time.

DISSOLVED SOLIDS: The residue from a clear sample of water after evaporation and drying for 1 hour at $180^{\circ}$ Celsius; consists primarily of dissolved mineral constituents, but may also contain organic matter.

DRAINAGE AREA: The drainage area of a stream at a specified location is that area, measured in a horizontal plane, which is enclosed by a drainage divide.

DRAINAGE BASIN: A part of the surface of the earth that is occupied by a drainage system, which consists of a surface stream or a body of impounded surface water together with all tributary surface streams and bodies of impounded surface water.

DRAINAGE DIVIDE: The rim of a drainage basin. Drainage divide, or just divide, is used to denote the boundary between one drainage area and another.

DRAWDOWN: The decline of water level in a well after pumping begins. It is the difference between the water level in a well after pumping begins and the water level as it would have been if pumping had not begun. 
DURATION OF FLOW, of a stream: The percentage of time during which specified daily discharges have been equaled or exceeded.

EVAPORATION: The process by which water is changed from the liquid or solid state into the vapor state. In hydrology, evaporation is vaporization that takes place at a temperature below the boiling point.

GAGING STATION: A particular site on a stream, canal, lake, or reservoir where systematic observations of gage height or discharge are obtained.

GAINING STREAM: A stream or reach of a stream whose flow is being increased by inflow of ground water.

GNEISS: A coarse-grained rock in which bands rich in granular minerals alternate with bands in which schistose minerals predominate.

GRANITE: A plutonic rock consisting essentially of alkalic feldspar and quartz.

GRAVEL-PACKED WELL: A well in which a filter material of gravel is placed in the annular space around the well screen to increase the effective diameter of the well and to prevent fine-grained sediments from entering the well.

GROUND WATER: Water in the ground that is in the zone of saturation, from which wells, springs, and ground-water runoff are supplied.

GROUND-WATER DISCHARGE: Water that is released from the saturated zone in the ground. It includes leakage of water into stream channels, lakes, and oceans; evapotranspiration; and withdrawal from wells.

GROUND-WATER DRAINAGE DIVIDE: A line on a water-table map on each side of which the water table slopes downward away from the line. It is analogous to a divide between two drainage basins on a land surface. Generally a ground-water drainage divide is found nearly below a surface-water drainage divide, but in some localities there is no relation between the two.

GROUND-WATER OUTFLOW: That part of the discharge from a drainage basin that occurs through the ground. The term "underflow" is often used to describe ground-water outflow that takes place in valley-fill material (instead of the surface channel) and thus is not measured at a gaging station.
GROUND-WATER RECHARGE: The amount of water that is added to the saturated zone.

GROUND-WATER RESERVOIR: A ground-water reservoir is defined in this report as that part of the sand and gravel aquifer where transmissivity and saturated thickness are greatest and where ground water may be present in quantities suitable for development and use. The outline of the ground-water model shown in figure 1 approximates the area of the upper Wood River ground-water reservoir.

GROUND-WATER RUNOFF: That part of the runoff which has passed into the ground, has become ground water, and has been discharged into a stream channel as spring or seepage water.

HARDNESS: A physical-chemical characteristic of water that is commonly recognized by the increased quantity of soap required to produce lather. It is attributable to the presence of alkaline earths (principally calcium and magnesium) and is expressed as equivalent calcium carbonate $\left(\mathrm{CaCO}_{3}\right)$. The following classification is used by the U.S. Geological Survey: soft, $0-60 \mathrm{mg} / \mathrm{L}$; moderately hard, $61-120 \mathrm{mg} / \mathrm{L}$; hard, $121-180 \mathrm{mg} / \mathrm{L}$; very hard, $181 \mathrm{mg} / \mathrm{L}$ and greater.

HEAD: The height above a standard datum of the surface of a column of water (or other liquid) that can be supported by the static pressure at a given point.

HETEROGENEITY: Heterogeneity is synonymous with nonuniformity. A material is heterogeneous if its hydrologic properties are not identical everywhere.

HYDRAULIC CONDUCTIVITY: The volume of water at the existing kinematic viscosity that will move in unit time under a unit hydraulic gradient through a unit area measured at right angles to the direction of flow. Hydraulic conductivity is in cubic foot per day per square foot or foot per day in reduced form (as used in this report).

HYDRAULIC GRADIENT: The change in static head per unit of distance in a given direction. If not specified, the direction generally is understood to be that of the maximum rate of decrease in head.

HYDROGRAPH: A graph showing stage (height), flow velocity, or other property of water with respect to time. 
INDUCED INFILTRATION: The process by which water moves into an aquifer from an adjacent surface-water body, owing to reversal of the hydraulic gradient, in response to pumping.

INDUCED RECHARGE: The amount of water entering an aquifer from an adjacent surfacewater body by the process of induced infiltration.

LEAKY BOUNDARY: A boundary condition that links boundary flux to boundary head. Its most common use is to represent the interaction between a water-table aquifer and a stream or river that is separated from the aquifer by a semipervious streambed layer.

LITHOLOGIC LOG: Description of geologic material collected during sampling of test wells.

LOSING STREAM: A stream or reach of a stream that is losing water to the ground.

MAXIMUM CONTAMINANT LEVEL: MaXimum concentration or level of a contaminant in drinking-water supplies as established by the U.S. Environmental Protection Agency and adopted by the Rhode Island Department of Health. Primary Maximum Contaminant Levels are based on health considerations and are legally enforceable. Secondary Maximum Contaminant Levels are based on esthetic considerations and are recommended guidelines.

MEAN (ARITHMETIC): The sum of the individual values of a set, divided by their total number, also referred to as the "average."

MEDIAN: The middle value of a set of measurements that are ordered from lowest to highest; 50 percent of the measurements are lower than the median, and 50 percent are higher.

pH: Symbol denoting the logarithm to base 10 of hydrogen-ion concentration in a solution. $\mathrm{pH}$ values range from 0 to 14 . The lower the value, the more hydrogen ions the solution contains. A value of 7.0 is the neutral point; values greater than 7.0 indicate an alkaline solution; values less than 7.0 indicate an acid solution.

PIEZOMETER: A device, usually a pipe, that is used for measuring hydraulic head in the field. It must be sealed along its length, open to water flow at the bottom, and open to the atmosphere at the top. The point of measurement in a piezometer is at its base, not at the level of the fluid surface.
PLUME: The volume of ground water degraded by migration and dispersion of one or more contaminants that have entered the aquifer.

PRECIPITATION: The discharge of water from the atmosphere, either in a liquid or solid state.

RECOVERY: The rise of the water level in a well after pumping has stopped. It is the difference between the water level in a well after pumping stops and the water level as it would have been if pumping had continued at the same rate.

RUNOFF: Part of precipitation that appears in surface streams. It is the same as streamflow unaffected by artificial diversion, storage, or other works of man in or on stream channels. Includes both surface- and ground-water runoff.

SATURATED THICKNESS: The thickness of an aquifer below the water table. As measured for the stratified-drift aquifer in this report, it is the vertical distance between the water table and the bedrock surface; in places, it includes till between the stratified drift and the bedrock surface.

SEASONAL KENDALL TEST: A modification of Kendall's Tau test that is restricted to those pairs of data that are multiples of 12 months apart. Comparing data from the same months of the year avoids the problem of seasonality. The Kendall Tau test is a nonparametric test for monotonic trend in which the relative values of data are compared. All possible pairs of data values are compared; if the later value is higher, a plus is tallied; if the later value is lower, a minus is tallied. An upward trend is likely if there are many more pluses than minuses; conversely, a downward trend is likely if there are more minuses than pluses. No trend is indicated if there is an equal number of pluses and minuses.

SEDIMENTARY ROCKS: A rock resulting from the consolidation of loose sediment that has accumulated in layers.

SEISMIC REFRACTION: A geophysical method often useful for determining the depth to the water table and (or) bedrock. A seismograph is used to measure the time it takes for a compressional sound wave generated by an energy source to travel down through layers of the Earth and back up to detectors placed on the land surface. 